\title{
Mepolizumab versus placebo for asthma
}

\section{Review information}

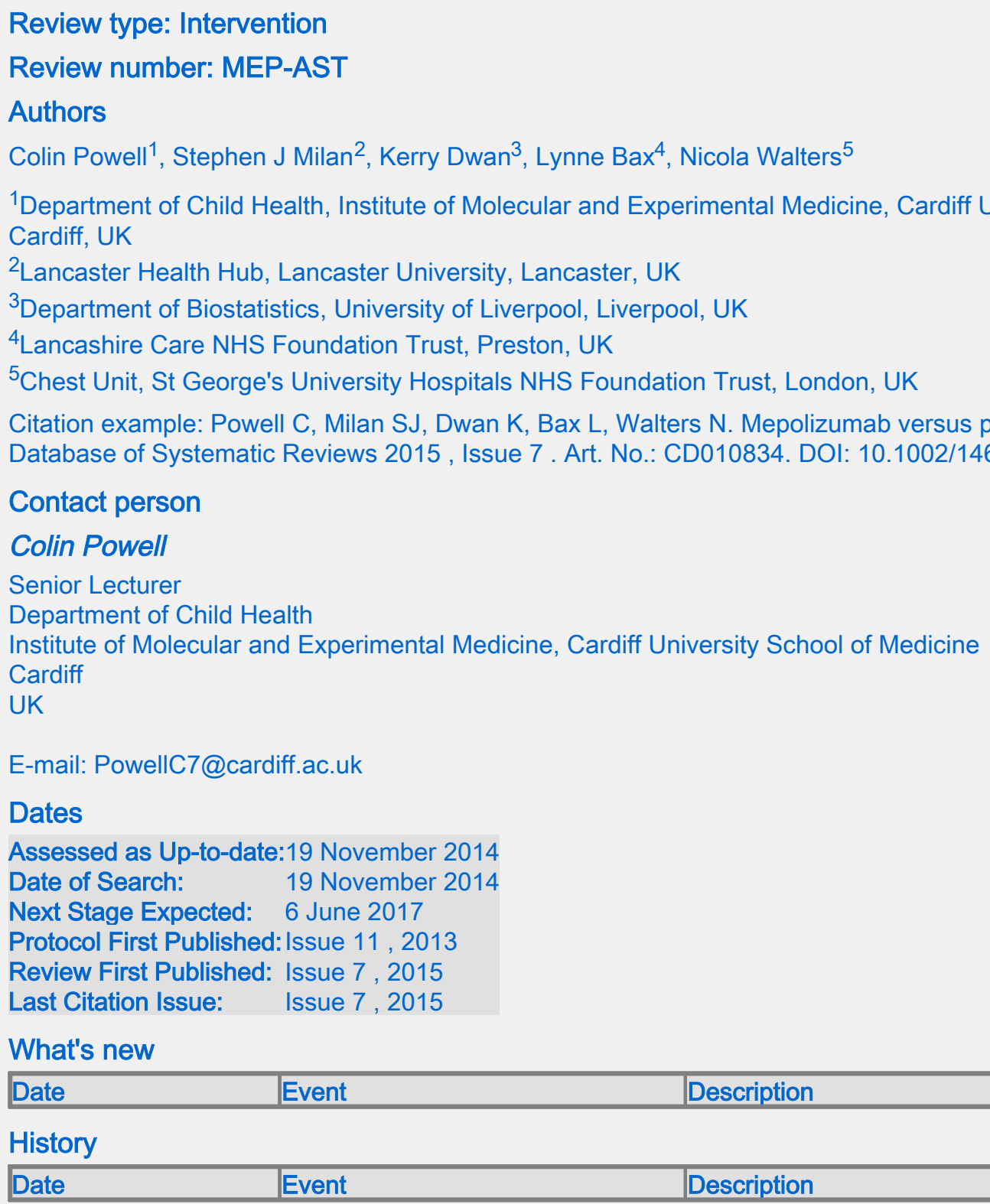

\begin{tabular}{|l|l|l}
\hline Date & Event & Description
\end{tabular}

\section{Abstract}

\section{Background}

Mepolizumab is a human monoclonal antibody against interleukin-5 (IL-5), the main cytokine involved in the activation of eosinophils, which in turn causes airway inflammation. Recent studies have suggested these agents may have a role in reducing exacerbations and improving health-related quality of life (HRQoL). There are no recommendations for the use of mepolizumab in adults or children in the recent update of the BTS/SIGN guidelines (BTS/SIGN 2014).

\section{Objectives}

To compare the effects of mepolizumab with placebo on exacerbations and HRQoL in adults and children with chronic asthma.

\section{Search methods}

We searched the Cochrane Airways Group Register (CAGR) of trials, clinical trial registries, manufacturers' websites and the reference lists of included studies. Searches were conducted in November 2013 and updated in November 2014.

\section{Selection criteria}

We included randomised controlled trials comparing mepolizumab versus placebo in adults and children with asthma.

Data collection and analysis 
Two authors independently extracted data and analysed outcomes using a random-effects model. We used standard methods expected by The Cochrane Collaboration.

\section{Main results}

Eight studies on 1707 participants met the inclusion criteria. Only two studies included children (over 12 years of age), but they did not report separate findings for the adolescents. Seven studies involved intravenous mepolizumab alone; one included a subcutaneous arm. There was heterogeneity in the severity and clinical pattern of asthma among the participants in the eight studies, varying from mild to moderate atopic asthma, to persistent asthma and eosinophilic asthma with recurrent exacerbations. Selection bias was a concern in several of the studies included in this review.

Four trials compared intravenous mepolizumab to placebo in relation to HRQoL. Two studies measured scores from the Asthma Quality of Life Questionnaire (AQLQ), which showed a non-significant difference between mepolizumab and placebo (mean difference $(\mathrm{MD}) 0.21,95 \%$ confidence interval $(\mathrm{Cl})-0.01$ to 0.44 ; participants $=682$ ), in the direction favouring mepolizumab. The third study used the St. George's Respiratory Questionnaire (SGRQ) and found a significant difference between mepolizumab and placebo (MD 6.40,95\% Cl 3.15 to 9.65; participants = 576), which indicated a clinically important benefit favouring mepolizumab. A fourth study noted that there was no significant difference but did not provide any data. The two studies in people with eosinophilic asthma showed a reduction in clinically significant exacerbation rates (Risk Ratio $0.52,95 \% \mathrm{Cl} 0.43$ to 0.64 ; participants $=690$ ). However, an analysis of four studies that were not confined to people with eosinophilic asthma indicated considerable heterogeneity and no significant difference in people with one or more exacerbations between mepolizumab and placebo using a random-effects model (Risk Ratio $0.67,95 \% \mathrm{Cl} 0.34$ to 1.31 ; participants $\left.=468 ; 1^{2}=59 \%\right)$. The analysis of serious adverse events indicated a significant difference favouring mepolizumab (Risk ratio $0.49,95 \% \mathrm{Cl} 0.30$ to 0.80 ; participants $=1441$; studies $=5 ; \mathrm{I}^{2}=0 \%$ ). It was not possible to combine the results for adverse events, and we deemed the quality of this evidence to be low.

A single study compared subcutaneous mepolizumab to placebo in 385 adults with severe eosinophilic asthma and found an improvement in HRQoL scores and a reduction in asthma exacerbations, including exacerbations requiring admission to hospital.

\section{Authors' conclusions}

It is not possible to draw firm conclusions from this review with respect to the role of mepolizumab in patients with asthma. Our confidence in the results of this review are limited by the fact that the intravenous route is not currently licensed for mepolizumab, and the evidence for the currently licenced subcutaneous route is limited to a single study in participants with severe eosinophilic asthma.

The currently available studies provide evidence that mepolizumab can lead to an improvement in health-related quality of life scores and reduce asthma exacerbations in people with severe eosinophilic asthma.

Further research is needed to clarify which subgroups of patients with asthma could potentially benefit from this treatment. Dosage, ideal dosing regimens and duration of treatment need to be clarified, as the studies included in this review differed in their protocols. There are no studies reporting results from children, so we cannot comment on treatment for this age group. At the present time, larger studies using licenced treatment regimens are required to establish the role of mepolizumab in the treatment of severe asthma.

\section{Plain language summary}

\section{Mepolizumab as opposed to placebo for asthma Review question}

We considered in this review whether taking mepolizumab is better than a placebo for people with asthma.

\section{Background}

Asthma is an inflammatory lung condition characterised by the narrowing of the airways, breathlessness, a tight chest and reduced quality of life. By the year 2025, there may be up to 400 million people with asthma worldwide. Mepolizumab is one treatment that may help to reduce the symptoms.

\section{Study characteristics}

Eight studies compared mepolizumab treatment to a placebo in 1707 patients with asthma. Six studies only included adults. We summarised the results as they relate to quality of life, occurrence of asthma attacks needing hospital admission and side effects of mepolizumab.

\section{Key results}

We found that patients with severe asthma who had high levels of eosinophils (inflammatory cells in the blood stream) benefited from taking mepolizumab through improved quality of life and reduced asthma attacks. There was no benefit in terms of lung function. We have avoided making recommendations because we think that further research is needed to clarify aspects such as dosage and length of treatment as well as which patients might benefit the most.

\section{Background}

\section{Description of the condition}

A recent global estimate of the number of people currently suffering from asthma is in the region of 300 million, and it is 
expected that by 2025 the number will increase to 400 million (WHO 2007). The subsequent burden of disease is likely to continue to impose additional pressures on patients, their families and healthcare systems (Masoli 2004). The increased incidence in morbidity has been associated with suboptimal delivery of care, including under-treatment with corticosteroids and a limited awareness of the condition amongst patients (Gibson 1993; Kandane-Rathayake 2009).

In the USA, the number of people with asthma increased from 20 million in 2001 to 25 million in 2009 (CDC 2011). Prevalence rates are slightly higher among children (10\%) than among adults (8\%) (CDC 2011; CDC 2012), with considerable variation among different ethnic groups. Between 2008 and 2010, asthma prevalence rates in the USA were $14.1 \%$ among multiracial individuals, $11.2 \%$ among blacks, 9.4\% among Alaska Natives, 9.4\% among other Native Americans, $7.7 \%$ among whites and 5.2\% among those of Asian descent (CDC 2011). Globally, the prevalence of wheezing symptoms in children varies geographically, with the UK having the highest recorded prevalence of current wheezing at $32.3 \%$ and Ethiopia the lowest at $1.7 \%$ (Patel 2008).

For many people, asthma has an important impact on quality of life (Clayton 2005) and on financial considerations (Wu 2007 ). In the USA, approximately 10 million people experience asthma exacerbations each year (Krishnan 2006), and in the UK, over 65,000 hospital admissions for asthma were recorded in 2005 and 2006 (NHS 2011).

In recent years, clinical guidelines have been produced for the management of asthma at national (e.g. BTS/SIGN 2014; NIH 2007) and international (GINA 2012) levels. Several risk factors for asthma have been identified, including triggers such as allergens, chemical irritants and tobacco smoke, but asthma-related mortality and morbidity remain a major health concern ( Braman 2006). On the other hand, the condition can also be controlled and health-related quality of life (HRQoL) maintained for considerable periods (WHO 2011).

\section{Description of the intervention}

One of the core pathological features of asthma is considered to be eosinophilic infiltration of the bronchial mucosa, which triggers an inflammatory response. Mepolizumab is a humanised monoclonal antibody against interleukin-5 (IL-5) that has been shown to inhibit eosinophilic airway inflammation. A number of studies have been conducted in young adults (> 12 years old) and adults with recurrent severe asthma exacerbations and signs of eosinophilic inflammation (Haldar 2009; Nair 2009; Pavord 2012). The results of these studies suggest that inhibiting eosinophilic inflammation by monoclonal antibodies may be associated with a reduced risk of acute exacerbations of asthma and a reduction in eosinophil count.

\section{How the intervention might work}

Proteins secreted by eosinophils cause damage to the epithelium, initiating vasodilatation, smooth muscle contraction and increased mucous secretion, which in turn is associated with increased airway hyperresponsiveness, asthma symptoms and airway narrowing (Liu 2013).

Mepolizumab is a key monoclonal antibody inhibiting IL-5, which is the main cytokine involved in eosinophil activation and recruitment. This intervention might work by preventing the initiation of the inflammatory response. Mepolizumab is administered intravenously as either a one-off dose of 2.5 to $10 \mathrm{mg} / \mathrm{kg}$ or monthly doses of $75 \mathrm{mg}, 250 \mathrm{mg}$ or $750 \mathrm{mg}$ given for a period ranging from 16 to 52 weeks. Mepolizumab can also be given subcutaneously.

\section{Why it is important to do this review}

In a recently published meta-analysis of seven randomised placebo-controlled trials on 1131 adults, mepolizumab was shown to reduce the risk of exacerbations and improve quality of life in people with eosinophilic asthma, but did not lead to a significant improvement in lung function (Liu 2013).

It is important to do this review so that the evidence presented and the judgements made in Liu 2013 are available and placed in context within The Cochrane Library. Our review will also set the stage for future updates as more evidence becomes available.

\section{Objectives}

To compare the effects of mepolizumab with placebo on exacerbations and HRQoL in adults and children with chronic asthma.

\section{Methods}

\section{Criteria for considering studies for this review}

\section{Types of studies}

We included randomised controlled trials (RCTs). We included studies reported as full text, those published as abstracts only and unpublished data. Included trials were a minimum of 16 weeks in duration.

\section{Types of participants}

We included both adults and children with a diagnosis of asthma. We focused on collating data from people who have been reported as having eosinophilic asthma to analyse these individuals as a subgroup. We examined individual articles in order to determine how this group should be defined.

Individuals with congential heart disease and respiratory comorbidities such as cystic fibrosis were excluded, as were current smokers. 
MEP-AST Mepolizumab versus placebo for asthma

We included trials comparing mepolizumab with placebo. We planned to include the following cointerventions provided they were not part of the randomised treatment: leukotriene antagonists, inhaled bronchodilators (including long-acting beta ${ }_{2}{ }^{-}$

agonists), systemic and inhaled steroids, oral aminophylline and macrolide antibiotics.

Studies that initiated a reduction in standard asthma management as part of the protocol were excluded. Nair 2009 included a reduction in the dose of prednisolone in the second phase of the trial. Therefore, only phase one of this trial was included as patients remained on their standard asthma treatment during this four-week period.

\section{Types of outcome measures}

Primary outcomes

1. HRQoL (as measured by a validated questionnaire)

2. Asthma exacerbation as defined by a hospital admission or treatment with a course of oral corticosteroids

3. Serious adverse events

\section{Secondary outcomes}

1. Measures of lung function: forced expiratory flow in one second $\left(F E V_{1}\right)$, peak expiratory flow rate (PEFR)

2. Asthma symptoms

3. Adverse events/side effects

4. Eosinophil counts in peripheral blood, sputum or bronchioalveolar lavage fluid

Reporting one or more of the outcomes listed here in the trial was not an inclusion criterion for the review.

\section{Search methods for identification of studies}

\section{Electronic searches}

We identified trials from the Cochrane Airways Group Specialised Register (CAGR), which is maintained by the Trials Search Co-ordinator for the Group. The Register contains trial reports identified through systematic searches of bibliographic databases, including the Cochrane Central Register of Controlled Trials (CENTRAL), MEDLINE, EMBASE, CINAHL, AMED and PsycINFO. We also handsearched respiratory journals and meeting abstracts (please see Appendix 1 for further details). We searched all records in the CAGR using the search strategy in Appendix 2.

We also conducted a search of ClinicalTrials.gov (www.clinicaltrials.gov) and the World Health Organization (WHO) trials portal (www.who.int/ictrp/en/).

We searched all databases from their inception to the present and imposed no restriction on language of publication. The search was first conducted in November 2013 and was updated in November 2014.

\section{Searching other resources}

We checked the bibliographies of all primary studies and review articles for additional references. We searched relevant manufacturers' websites for trial information.

We searched for errata and retractions relevant to the included studies published in full text on PubMed (www.ncbi.nlm.nih.gov/pubmed) and planned to report the date this was done within the review if this was an issue.

\section{Data collection and analysis}

\section{Selection of studies}

Two rreview authors (NW, CP) independently screened titles and abstracts of all the potential studies identified in the search and coded them as 'retrieve' (eligible or potentially eligible/unclear) or 'do not retrieve'. We retrieved the full-text study reports/publications, and two review authors (NW, CP) independently screened the full text and identified studies for inclusion, identifying and recording reasons for excluding the ineligible studies. We planned to resolve any disagreement through discussion or, if required, by consulting a third author (SJM); however, this was not necessary. We identified and excluded duplicates and collated multiple reports of the same study so that each study rather than each report was the unit of interest in the review. We recorded the selection process in sufficient detail to complete a PRISMA flow diagram and a ' Characteristics of excluded studies' table.

\section{Data extraction and management}

We used a data collection form to record study characteristics and outcome data that had been piloted on at least one study in the review. Two review authors (LB, NW) extracted the following study characteristics from included studies.

1. Methods: study design, total duration of study, details of any run-in period, number of study centres and location, study setting, withdrawals and date of study.

2. Participants: number, mean age, age range, gender, severity of condition, diagnostic criteria, baseline lung function, smoking history, inclusion criteria and exclusion criteria.

3. Interventions: intervention, comparator, concomitant medications and excluded medications.

4. Outcomes: primary and secondary outcomes specified and collected, and time points reported.

5. Notes: funding for trial and notable conflicts of interest of trial authors.

Two review authors (LB, NW) independently extracted outcome data from included studies. We noted in the 'Characteristics of included studies' table if outcome data were not reported in a usable way. We planned to resolve disagreements by consensus or by involving a third author (CP), but this was not necessary. One review author (KD) transferred data into 
Review Manager (RevMan). We double-checked that data were entered correctly by comparing the data presented in the systematic review with the study reports. A second review author (SJM) spot-checked study characteristics for accuracy against the trial report.

\section{Assessment of risk of bias in included studies}

Two review authors (LB, NW) independently assessed risk of bias for each study using the criteria outlined in the 7 Cochrane Handbook for Systematic Reviews of Interventions $\neg$ (Higgins 2011). We planned to resolve any disagreements by discussion or by involving another author (SJM), but this was not necessary. We assessed the risk of bias according to the domains:

1. random sequence generation;

2. allocation concealment;

3. blinding of participants and personnel;

4. blinding of outcome assessment;

5. incomplete outcome data;

6. selective outcome reporting;

7. other bias.

We graded each potential source of bias as high, low or unclear, and provided a quotation from the study report together with a justification for this judgement in the 'Risk of bias' table. We summarised the risk of bias judgements across different studies for each of the domains listed. We considered blinding separately for different key outcomes where necessary (e.g. for an unblinded outcome assessment, risk of bias for all-cause mortality may be very different than that for a patientreported pain scale). Where information on risk of bias related to unpublished data or correspondence with a trialist, we noted this in the 'Risk of bias' table.

When considering treatment effects, we took into account the risk of bias for the studies that contributed to that outcome.

We conducted the review according to this published protocol and have reported any deviations from it in the 'Differences between protocol and review' section of the systematic review.

\section{Measures of treatment effect}

We analysed dichotomous data as risk ratios and rate ratios and continuous data as mean differences or standardised mean differences, which are presented with $95 \%$ confidence intervals. We entered data presented on a scale with a consistent direction of effect. However, on one occasion we had to use the risk ratio as one study had reported this (Haldar 2009).

We have undertaken meta-analyses only where this was meaningful (i.e. if the treatments, participants and underlying clinical question were sufficiently similar for pooling to make sense).

Where multiple trial arms were reported in a single trial (Flood-Page 2007; Pavord 2012), we combined the relevant arms (750 mg, 250 mg, 75 mg in Pavord 2012 and 750 mg, 250 mg in Flood-Page 2007) when appropriate.

In future updates of this review, we will narratively describe skewed data reported as medians and interquartile ranges. Where multiple trial arms are reported in a single trial, we will include only the relevant arms. If two comparisons (e.g. drug A versus placebo and drug B versus placebo) are combined in the same meta-analysis, we will halve the control group to avoid double-counting.

\section{Unit of analysis issues}

No cross-over studies or cluster randomised trials were identified for inclusion in this version of the review. If cross-over trials are identified in the future, data from a paired analysis will be sought from the trial report or authors in order to appropriately include data in the review using the inverse variance method. If cluster randomised trials are identified in the future, then analyses will be at the level of the individual while allowing for the clustering in the data by using the intracluster correlation coefficient. If this is not reported in the trial, then it will be imputed from similar studies.

\section{Dealing with missing data}

Although unnecessary for this version of the review, we may contact investigators or study sponsors for future versions in order to verify key study characteristics and obtain missing numerical outcome data where possible (e.g. when a study is identified as an abstract only). Where this is not possible, and the missing data are thought to introduce serious bias, we will explore the impact of including such studies in the overall assessment of results by a sensitivity analysis. 7

\section{Assessment of heterogeneity}

Statistical heterogeneity between studies was assessed visually by inspection of the forest plots and using the Chi ${ }^{2}$ test $(\mathrm{a} P$ value $<0.10$ was considered significant due to the low power of the test). The $\mathrm{I}^{2}$ statistic was also calculated; this describes the percentage of the variability in effect estimates that is due to heterogeneity rather than sampling error (chance). Values of $\mathrm{I}^{2}$ range from $0 \%$ to $100 \%$, with $0 \%$ representing no heterogeneity and $100 \%$ representing considerable heterogeneity.

For this review, heterogeneity as reported using the $\mathrm{I}^{2}$ statistic was defined as follows.

- $0 \%$ to $40 \%$ : heterogeneity might not be important.

- $30 \%$ to $60 \%$ : may represent moderate heterogeneity.

- $50 \%$ to $90 \%$ : may represent substantial heterogeneity.

- $75 \%$ to $100 \%$ : considerable heterogeneity. 
MEP-AST Mepolizumab versus placebo for asthma

\section{Assessment of reporting biases}

If we are able to pool more than 10 trials for future versions, we will create and examine a funnel plot to explore possible small study biases and publication bias.

\section{Data synthesis}

In view of the considerable clinical heterogeneity between the included studies, we used a random-effects model.

Data on outcomes were combined at 6 months and 12 months. Where data for other time points were reported, these were also described.

\section{Subgroup analysis and investigation of heterogeneity}

Provided sufficient studies were included, we planned to carry out subgroup analyses according to:

1. age ( 0 to 5 years, 6 to 16 years, 17 years and older);

2. eosinophilic individuals versus non-eosinophilic individuals; and

3. dose of intervention (posthoc subgroup identified);

using the outcomes:

1. HRQoL; and

2. asthma symptoms.

If more studies are included in the future, we will use the formal test for subgroup interactions in RevMan.

\section{Sensitivity analysis}

We planned to carry out the following sensitivity analyses if sufficient studies were included.

1. Excluding studies with an overall high risk of bias.

2. Excluding cross-over trials and cluster randomised trials.

\section{Summary of findings table}

We created 'Summary of findings' tables using the following outcomes.

1. HRQoL.

2. Asthma exacerbation as defined by a hospital admission or treatment with a course of oral corticosteroids.

3. Serious adverse events.

We used the five GRADE considerations (study limitations, consistency of effect, imprecision, indirectness and publication bias) to assess the quality of the body of evidence as it relates to the studies that contribute data to the meta-analyses for the prespecified outcomes. We used methods and recommendations described in Section 8.5 and Chapter 12 of the Cochrane Handbook for Systematic Reviews of Interventions (Higgins 2011) using GRADEpro software. We have justified all decisions to downgrade or upgrade the quality of studies using footnotes, and we have made comments to aid the reader's understanding of the review where necessary.

\section{Results}

\section{Description of studies}

Results of the search

We identified 154 records in our literature searches: 129 in database searches in November 2013 and a further 25 in November 2014 (Figure 1). Eight studies met our inclusion criteria ('Characteristics of included studies' table), and two others were included in the ongoing studies category ('Characteristics of ongoing studies' table). The eight included studies had 25 records: one for Buttner 2003; seven for Flood-Page 2003, one for Flood-Page 2007, four for Haldar 2009, one for Leckie 2000; five for Nair 2009; two for Ortega 2014 and four for Pavord 2012. The remaining 127 records were excluded for various reasons ('Characteristics of excluded studies' table).

\section{Included studies}

We included eight studies ('Characteristics of included studies' table), involving 1707 total participants distributed as follows: Buttner 2003, 19; Flood-Page 2003, 24; Flood-Page 2007, 362; Haldar 2009, 61; Leckie 2000, 24; Nair 2009, 20; Ortega 2014, 576 Pavord 2012, 621. Table 1 compares the design, numbers, interventions and patient groups in the included trials. The severity of asthma among participants varied from mild atopic asthma to persistent eosinophilic asthma with recurrent exacerbations. The mepolizumab was administered exclusively through intravenous route in seven of the studies, with dosage varying from $2.5 \mathrm{mg} / \mathrm{kg}$ or $10 \mathrm{mg} / \mathrm{kg}$, or $75 \mathrm{mg}, 250 \mathrm{mg}$ and $750 \mathrm{mg}$ with different dosing regimens over a range of treatment periods. Only one study had a subcutaneous (SC) arm, with a dose of $100 \mathrm{mg}$ (Ortega 2014).

\section{Excluded studies}

We excluded 127 records from the review. Of these, 119 (94\%) were excluded because mepolizumab had not been included in the study, $4(3 \%)$ were excluded because they did not include a placebo arm, another $2(2 \%)$ were excluded because the focus was on steroid reduction, $1(1 \%)$ was non-randomised, and the remaining study (1\%) was conducted on healthy participants without a diagnosis of asthma ('Characteristics of excluded studies' table). 
Details of our risk of bias assessments are available in the 'Characteristics of included studies' table, and a summary of our assessment can be seen in Figure 2 and Figure 3.

\section{Allocation (selection bias)}

We deemed only three studies (Nair 2009; Pavord 2012; Ortega 2014) to be at low risk of bias for both random sequence generation and allocation concealment. We judged Haldar 2009 to be at low risk of bias for random sequence generation, but its bias with regard to allocation concealment was unclear. The risk of bias for the remaining four studies (Buttner 2003; Flood-Page 2003; Flood-Page 2007; Leckie 2000) was unclear for both random sequence generation and allocation concealment (Figure 3).

\section{Blinding (performance bias and detection bias)}

With regard to performance bias and detection bias, we determined that all eight studies were at low risk of bias (Figure 3 ).

\section{Incomplete outcome data (attrition bias)}

In terms of attrition bias, we considered seven of the studies to be at low risk of bias, while the risk of bias in Buttner 2003 was unclear (Figure 3).

\section{Selective reporting (reporting bias)}

One study noted that there was no significant difference in HRQoL but did not provide any data (Flood-Page 2007), so we considered it to be at high risk of bias. We deemed all other studies to be at low risk of bias as there was no apparent evidence of selective reporting.

\section{Effects of interventions}

\section{Primary outcomes}

\section{HRQoL (as measured by a validated questionnaire)}

Three studies (participants $=1044$ ) measured quality of life using the Asthma Quality of Life Questionnaire (AQLQ) (FloodPage 2007; Haldar 2009; Pavord 2012). One study noted that there was no significant difference but did not provide any data (Flood-Page 2007).

\section{Intravenous mepolizumab versus placebo}

Pavord 2012 reported data at 52 weeks for three different dose groups of Intravenous (IV) mepolizumab (75 mg, $250 \mathrm{mg}$, $750 \mathrm{mg}$ ), which we combined and presented as one group. Haldar 2009 reported data at 50 weeks. Combining the two studies, Analysis 1.1 showed a non-significant difference between IV mepolizumab and placebo (MD $0.21,95 \% \mathrm{Cl}-0.01$ to 0.44; participants $=682$ ), favouring IV mepolizumab. Our confidence in this result is low, as the mean difference is less the clinical minimally important difference of 0.5 units, and no responder analysis is reported (Summary of findings table 1).

Ortega 2014 measured quality of life using the St. George's Respiratory Questionnaire (SGRQ) and found a significant difference favouring IV mepolizumab over the placebo (MD 6.40, 95\% Cl 3.15 to 9.65; participants = 382; Analysis 1.2). We only have moderate confidence in this result, as IV delivery is not currently a licenced route of administration for mepolizumab (Summary of findings table 1).

\section{Subcutaneous mepolizumab versus placebo}

Ortega 2014 measured quality of life using the St. George's Respiratory Questionnaire (SGRQ) and found a significant difference between subcutaneous (SC) mepolizumab and placebo, in favour of mepolizumab (MD $-7.00,95 \% \mathrm{Cl}-10.19$ to -3.81 ; participants $=385$; Analysis 2.1). We have moderate confidence in this result from a single study (Summary of findings table 2).

\section{Asthma exacerbation as defined by a hospital admission or treatment with a course of oral corticosteroids}

Six studies (participants $=1664$ ) reported on asthma exacerbations (Flood-Page 2003; Flood-Page 2007; Haldar 2009; Nair 2009; Pavord 2012; Ortega 2014). Increase in oral corticosteroids is included in the definition of exacerbation for three studies (Haldar 2009; Ortega 2014; Pavord 2012). Two studies did not include an increase in oral corticosteroids in the definition of exacerbation (Flood-Page 2007; Nair 2009), while one study did not provide a definition of exacerbation (FloodPage 2003).

\section{Mepolizumab versus placebo}

Four studies ( Flood-Page 2003; Flood-Page 2007; Haldar 2009; Nair 2009) reported the number of patients experiencing an exacerbation. Analysis 1.6, which used a random-effects model, did not show a significant difference between IV mepolizumab and placebo (Risk Ratio $0.67,95 \% \mathrm{Cl} 0.34$ to 1.31 ; participants $=468 \mathrm{I}^{2}=59 \%$ ). Our confidence in this result is low due to the wide confidence intervals (Summary of findings table 1).

Pavord 2012 reported the rate ratio of exacerbations for each of the three different dose groups of IV mepolizumab compared to placebo. Ortega 2014 reported the percentage reduction in the rate ratio for clinically significant exacerbations for $75 \mathrm{mg}$ IV mepolizumab compared to placebo. We combined the results for groups taking the $75 \mathrm{mg}$ dose from these studies, both of which included participants with severe eosinophilic asthma.

Analysis 1.3 shows similar results for the rate of clinically significant exacerbations, which include a course of oral steroids, emergency department (ED) visit or admission. For the $75 \mathrm{mg}$ dose, the rate of ED visits or hospital admissions for people on mepolizumab was half that of the placebo group (rate ratio $0.52,95 \% \mathrm{Cl} 0.43$ to 0.64 ; participants $=690$; studies $=2$ ). For the $250 \mathrm{mg}$ dose, the result was similar (rate ratio $0.61,95 \% \mathrm{Cl} 0.46$ to 0.81 ; participants $=307$; studies $=1$ ) and also for the 
$750 \mathrm{mg}$ dose (rate ratio $0.48,95 \% \mathrm{Cl} 0.36$ to 0.64 ; participants $=311$; studies $=1$ ). Our confidence in this result is moderate, as IV delivery is not currently a licenced delivery route for mepolizumab (Summary of findings table 1).

Analysis 1.4 shows the rate ratio for the combined results of these two studies in terms of exacerbations requiring hospital admission, and there is not a significant difference for the $75 \mathrm{mg}$ mepolizumab dose (rate ratio $0.61,95 \% \mathrm{Cl} 0.33$ to 1.13 ; participants $=690$; studies $=2$ ). The $750 \mathrm{mg} \mathrm{IV} \mathrm{mepolizumab} \mathrm{group} \mathrm{compared} \mathrm{to} \mathrm{placebo} \mathrm{showed} \mathrm{a} \mathrm{reduction} \mathrm{in} \mathrm{the} \mathrm{risk} \mathrm{of}$ being admitted to hospital (rate ratio $0.37,95 \% \mathrm{Cl} 0.16$ to 0.86 ; participants $=311$; studies $=1$ ). The $250 \mathrm{mg}$ dose did not show a statistically significant reduction (rate ratio $0.65,95 \% \mathrm{Cl} 0.31$ to 1.37 ; participants $=307$; studies $=1$ ), but the difference between doses was not significant (test for subgroup differences: $\mathrm{Chi}^{2}=1.14$, degree of freedom $(\mathrm{df})=2(\mathrm{P}=$ $\left.0.57), 1^{2}=0 \%\right)$.

Analysis 1.5 shows the combined results on exacerbations requiring a visit to the ED or hospital admission. For the $75 \mathrm{mg}$ dose, there was a significant reduction in the exacerbation rate for this outcome (rate ratio $0.52,95 \% \mathrm{Cl} 0.31$ to 0.87 ; participants $=690$; studies $=2$ ), and although the reduction in rate was similar for the other doses, it did not reach statistical significance ( $250 \mathrm{mg}$ dose: rate ratio $0.58,95 \% \mathrm{Cl} 0.30$ to 1.12; participants $=307$; studies $=1$; and $750 \mathrm{mg}$ dose: rate ratio $0.52,95 \% \mathrm{Cl} 0.27$ to 1.02 ; participants $=311$; studies $=1$ ). Again there was no significant difference between the results according to dose (test for subgroup differences: $\left.\mathrm{Chi}^{2}=0.08, \mathrm{df}=2(\mathrm{P}=0.96), \mathrm{I}^{2}=0 \%\right)$.

\section{SC Mepolizumab versus placebo}

Ortega 2014 also found a reduction in the rate of all of the above types of exacerbations favouring SC mepolizumab in comparison to placebo. Analysis 2.2 shows the results for hospital admission (rate ratio $0.31,95 \% \mathrm{Cl} 0.11$ to 0.91 ; participants $=385$; studies $=1$ ). Analysis 2.3 shows the reduction in either ED visits or hospital admission (rate ratio 0.39 , $95 \% \mathrm{Cl} 0.18$ to 0.83 ; participants $=385$; studies $=1$ ). Analysis 2.4 shows the reduction in clinically significant exacerbations (rate ratio $0.47,95 \% \mathrm{Cl} 0.35$ to 0.63 ; participants $=385$; studies $=1$ ). We have moderate confidence in these results from a single study (Summary of findings table 2).

\section{Serious adverse events}

Five studies (participants $=1640$ ) reported information on serious adverse events.

Nair 2009 stated that there were no serious adverse events, while Pavord 2012 reported that the overall frequency of serious adverse events was similar across treatment groups and that no serious life-threatening anaphylactic reactions were observed; however, three patients in the IV mepolizumab groups died during the study for reasons that the physician investigator judged to be unrelated to the treatment.

Flood-Page 2007 reported nine serious adverse events: four in patients receiving placebo (vertigo, bladder carcinoma, unintended pregnancy and asthma exacerbation), three in patients receiving IV mepolizumab $250 \mathrm{mg}$ (hydrocephalus/cerebrovascular disorder, constipation and gastrointestinal disturbance), and two in patients receiving IV mepolizumab $750 \mathrm{mg}$ (asthma exacerbation). None of these serious adverse events was considered to be related to the study medication, and there were no significant differences between the treatment groups.

Haldar 2009 reported that hospitalisation for asthma was a serious adverse effect for $10 \%(3 / 29)$ of participants in the IV mepolizumab arm and $34 \%(11 / 32)$ in the placebo arm.

Ortega 2014 reported that the incidence of serious adverse events (including asthma-related events) was $7 \%$ in the intravenous mepolizumab group, $8 \%$ in the subcutaneous mepolizumab group, and $14 \%$ in the placebo group.

Analysis 1.7 indicated that there was a significant difference between IV mepolizumab versus placebo (Risk Ratio 0.49 , 95\% $\mathrm{Cl} 0.30$ to 0.80 ; participants $=1441$; studies $=5 ; \mathrm{I}^{2}=0 \%$ ), favouring IV mepolizumab. Our confidence in this result is moderate, as IV delivery is not currently a licenced route of administration for mepolizumab (Summary of findings table 1).

\section{Secondary outcomes}

\section{Measures of lung function: forced expiratory flow in one second $\left(F E V_{1}\right)$, peak expiratory flow rate (PEFR)}

Seven studies (participants $=1688)$ report on lung function (Flood-Page 2003; Flood-Page 2007; Haldar 2009; Leckie 2000; Nair 2009; Pavord 2012; Ortega 2014).

\section{Mepolizumab versus placebo}

Flood-Page 2003 reported no difference between IV mepolizumab and placebo for median FEV 1 and median PEFR at 12 weeks (Table 2).

Flood-Page 2007 reported mean change from placebo for $\mathrm{FEV}_{1}(\mathrm{~L})$ and PEFR L/min at weeks 12 and 20 . Analysis 1.8 indicates there was no significant difference in $\mathrm{FEV}_{1}$ between IV mepolizumab and placebo at week 20 . Analysis 1.9 shows a significant difference for IV mepolizumab $250 \mathrm{mg}$ compared to placebo (MD 13.49; 95\% Cl 0.71 to 26.27 ), but not for the 750 mg compared to placebo group (MD 3.42, 95\% Cl - 9.40 to 16.24). However, the test for subgroup difference was not significant $\left(\mathrm{Chi}^{2}=1.19, \mathrm{df}=1(\mathrm{P}=0.280), \mathrm{I}^{2}=15.9 \%\right)$.

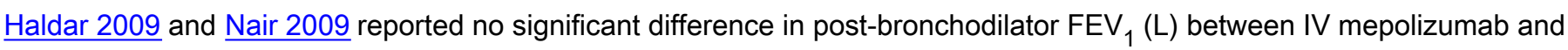
placebo at one year and six weeks, respectively (Analysis 1.10). Nair 2009 also reported no difference between IV mepolizumab and placebo for percentage predicted $\mathrm{FEV}_{1}$ after bronchodilation (Analysis 1.11). 
MEP-AST Mepolizumab versus placebo for asthma

Pavord 2012 found no significant difference between any dose of IV mepolizumab and placebo in pre-bronchodilator FEV 1

$(\mathrm{mL})$ at one year (Analysis 1.13).

Leckie 2000 reports no significant difference between IV mepolizumab and placebo in late asthmatic reaction (maximum percentage fall in $\mathrm{FEV}_{1}$ ) (Analysis 1.14).

Ortega 2014 reported a statistically significant difference favouring IV mepolizumab for both pre- and post-bronchodilator FEV1 (MD 0.10 L ; $95 \%$ Cl 0.01 to 0.19); (MD 0.15 L, 95\% Cl 0.05 to 0.24), (Analysis 1.10; Analysis 1.12).

SC Mepolizumab versus placebo

Ortega 2014 reported a statistically significant difference favouring SC mepolizumab for both pre- and post-bronchodilator $\mathrm{FEV}_{1}$ (MD 0.10, 95\% Cl 0.02 to 0.18; participants = 385; studies = 1 and MD $0.14,95 \% \mathrm{Cl} 0.04$ to 0.23 ; respectively) (

Analysis 2.5; Analysis 2.6;).

\section{Asthma symptoms}

Five studies (participants = 1640) measured asthma symptoms (Flood-Page 2007; Haldar 2009; Nair 2009; Pavord 2012; Ortega 2014).

\section{Mepolizumab versus placebo}

Flood-Page 2007 reported results at 20 weeks using the asthma summary symptom score. Nair 2009 reported data at 4 weeks using a symptom score, a cough score and the Juniper Asthma Cough Questionnaire (JACQ) score. Haldar 2009 reported data at one year using the visual analogue scale symptom score and a modified Juniper Asthma Control Score. Pavord 2012 reported data using the asthma control questionnaire at one year. Ortega 2014 reported data at 32 weeks using the five-item Asthma Control Questionnaire (ACQ-5).

There were no significant differences between IV mepolizumab at $250 \mathrm{mg}$ or $750 \mathrm{mg}$ and placebo using an asthma symptom score or the JACQ, but there was a significant difference between $75 \mathrm{mg}$ and placebo (MD $-0.30,95 \% \mathrm{Cl}-0.55$ to -0.04 ; participants $=690$; studies $=2$; Analysis 1.15), although test for subgroup difference was again non-significant $\left(\right.$ Chi ${ }^{2}=0.81$, $\left.\mathrm{df}=2(\mathrm{P}=0.67), \mathrm{I}^{2}=0 \%\right)$.

\section{SC Mepolizumab versus placebo}

There was also a statistically significant improvement in symptoms on SC mepolizumab compared to placebo (MD - 0.44 , $95 \% \mathrm{Cl}-0.64$ to -0.24 ; participants $=385$; studies $=1$ ); Analysis 2.7 ). However, there was no responder analysis, and this mean difference is less than the minimal clinically important difference of -0.5 units.

\section{Adverse events/side effects}

Six studies (participants $=1664)$ reported adverse events (Flood-Page 2003; Flood-Page 2007; Haldar 2009; Nair 2009; Pavord 2012; Ortega 2014).

Flood-Page 2003 reported that all of the 24 volunteers completed the study without reporting adverse events.

Flood-Page 2007 reported that there were no significant differences between the treatment groups for any adverse events reported. The most common adverse events (at least $5 \%$ of participants in any treatment group) were upper respiratory tract infection, asthma, headache, rhinitis, bronchitis, sinusitis, viral infection, injury, back pain, nausea and pharyngitis.

Haldar 2009 reported that one patient withdrew due to rash after mepolizumab infusion.

Nair 2009 reported that one patient in the IV mepolizumab group withdrew because of increased shortness of breath, thought to be due to heart failure. One patient in the placebo group died six months after the study because of sudden cardiac arrest; one patient in the IV mepolizumab group reported aches and tiredness when prednisolone was reduced, and one patient in the placebo group had hypoadrenalism when prednisolone was reduced.

Pavord 2012 found that the most frequently reported adverse events were headache (27 (17\%) individuals given placebo, 32 (21\%) given 75 mg IV mepolizumab, 32 (21\%) given 250 mg IV mepolizumab, and 32 (21\%) given 750 mg IV mepolizumab) and nasopharyngitis (24 (15\%), $34(22 \%), 33(22 \%)$, and $29(19 \%)$ for the four groups, respectively). The most frequently reported drug-related adverse event was infusion-related reaction (e.g. non-allergic reactions), which was reported by 10 (6\%) patients given placebo, 8 (5\%) given 75 mg mepolizumab, 12 (8\%) given 250 mg IV mepolizumab, and 19 (12\%) given $750 \mathrm{mg}$ IV mepolizumab. Hypersensitivity deemed to be possibly related to investigational product was reported by three patients (2\%) given placebo, none given $75 \mathrm{mg}$ IV mepolizumab, one (< 1\%) given $250 \mathrm{mg}$ IV mepolizumab, and two (1\%) given $750 \mathrm{mg}$ IV mepolizumab.

In the Ortega 2014 study, the overall incidence of adverse events during treatment was similar in the three groups (84\% in the IV mepolizumab group, $78 \%$ in the SC mepolizumab group, and $83 \%$ in the placebo group). The most frequently reported adverse events were nasopharyngitis and headache. The incidence of adverse events that were considered by the study investigators to be related to a study drug was $17 \%$ in the IV mepolizumab group, $20 \%$ in the SC mepolizumab group, and $16 \%$ in the placebo group. The incidence of injection-site reactions was more frequent in the SC mepolizumab group (9\%) than in the IV mepolizumab group or the placebo group ( $3 \%$ in each).

\section{Eosinophil counts in peripheral blood, sputum or bronchioalveolar lavage fluid}

All eight studies (participants $=1707$ ) report on eosinophil counts (Buttner 2003; Flood-Page 2003; Flood-Page 2007; Haldar 2009; Leckie 2000; Nair 2009; Pavord 2012; Ortega 2014). 
Buttner 2003 found that "[a]sthmatic patients received three consecutive intravenous infusions of either IV mepolizumab (250 $\mathrm{mg}$ or $750 \mathrm{mg}$ per dose) or placebo at 4-week intervals. Remarkably, almost a complete disappearance of peripheral blood eosinophils was observed after the first infusion. Eosinophil counts remained low or absent until week 24, 12 weeks after the last infusion. In contrast, there were no significant changes in eosinophil counts in the placebo group. The marked fall in peripheral blood eosinophils was accompanied by a significant decrease in ECP concentrations. The kinetics of ECP (serum eosinophil cationic protein) levels resembled the eosinophil counts. These qualitative and quantitative changes were observed in both treatment groups without a significant difference between the 250 and 750 mg dosage."

Flood-Page 2003 found that at four weeks after the first dose of IV mepolizumab, there was a significant decrease in peripheral blood eosinophil counts in the actively treated group when compared with placebo $(P=0.002)$. This decrease was maintained throughout the dosing period and was still evident at the time of the repeat bronchoscopy and bone marrow aspirate, [at] Week $10(P=0.02)$. There was a median reduction of $100 \%$ from baseline of eosinophils in the actively treated group at Weeks 4 and 10 (interquartile range, 67-100\%). A return of blood eosinophil counts toward baseline was observed at a mean of 9 weeks after the last dose (range 4-20 weeks, data not shown). IV mepolizumab produces a 79\% median reduction in bronchoalveolar lavage fluid (BALF) eosinophils (interquartile range, 42-99\%) $(P=0.4$ when compared with placebo) (Table 3).

Flood-Page 2007 found a significant reduction in the eosinophil counts in the $250 \mathrm{mg}$ and $750 \mathrm{mg}$ groups at week 1 (P< 0.001). Also, 32 patients gave samples at baseline and week 12; 17 had sputum eosinophils $>3 \%$. There was a significant decrease in both the $250 \mathrm{mg}(P=0.006)$ and the $750 \mathrm{mg}$ group $(P=0.004)$, which was also significant when compared to placebo.

Haldar 2009 reports a significant difference between IV mepolizumab and placebo for geometric mean sputum eosinophil percentage during exacerbation, and a sputum eosinophil count $>3 \%$ during exacerbation (\% of episodes), Table 4 . The study also reports, "[T]he geometric mean of eosinophil counts in the blood during the treatment phase, as compared with the baseline value, was reduced by a factor of 6.6 in the mepolizumab group and by a factor of 1.1 in the placebo group, with the changes from baseline differing between the groups by a factor of $6.1(95 \% \mathrm{Cl}, 4.1$ to 8.9 ; $\mathrm{P}<0.001)$."

Results from Leckie 2000 are presented in Table 5. There was a significant reduction in blood eosinophils pre-allergen challenge in the group given mepolizumab $10 \mathrm{mg} / \mathrm{kg}$. Postinhaled allergen, there was a significant reduction in blood eosinophils in both groups given mepolizumab. There was a dose dependent reduction in sputum eosinophils in both mepolizumab groups. This result reached statistical significance in the $10 \mathrm{mg} / \mathrm{kg}$ group.

Ortega 2014 found a significant decrease in both treatment groups in blood eosinophil count.

Results from Nair 2009 can be found in Table 6. In phase 1 of the trial, a single infusion of mepolizumab 750 mg resulted in a reduction in the number of sputum and blood eosinophils.

Pavord 2012 found that compared with placebo, the ratios of geometric means at 52 weeks showed that the drug reduced blood eosinophil counts (ratios of geometric means $0.22,95 \% \mathrm{Cl} 0.18$ to 0.27 ) in individuals given 75 mg mepolizumab (P< 0.0001 ; ratios of geometric means $0.14 ; 95 \% \mathrm{Cl} 0.12$ to 0.18$)$, in those given $250 \mathrm{mg}$ mepolizumab, $(\mathrm{P}<0.0001$; ratios of geometric means $0.12 ; 95 \% \mathrm{Cl} 0.09$ to 0.14$)$ and in those given $750 \mathrm{mg}$ mepolizumab, $(\mathrm{P}<0.0001)$. In the subgroup of 94 participants who had sputum induction, the drug also caused decreases in sputum eosinophil counts compared with placebo (ratio $0.68 .95 \% \mathrm{Cl} 0.13$ to 3.52 ), in individuals given $75 \mathrm{mg}$ mepolizumab ( $\mathrm{P}=0.6429$; ratios of geometric means $0.35,95 \%$ $\mathrm{Cl} 0.08$ to 1.52$)$, in those given $250 \mathrm{mg}$ mepolizumab $(\mathrm{P}=0.1577 ; 0.1295 \% \mathrm{Cl} 0.02$ to 0.56$)$ and in those given $750 \mathrm{mg}(\mathrm{P}=$ $0.0082)$.

\section{Discussion}

\section{Summary of main results}

Eight studies met our inclusion criteria for this systematic review (Buttner 2003; Flood-Page 2003; Flood-Page 2007; Haldar 2009; Leckie 2000; Nair 2009; Pavord 2012; Ortega 2014). Six studies included adults participants only, while Pavord 2012 and Ortega 2014 included participants aged 12 years and over, with a mean age of around 50 years and no separate reporting of results in adolescents. In total, 1707 people participated.

The results suggest that mepolizumab leads to an improvement in HRQoL and a reduction in asthma exacerbation rates for people with severe eosinophilic asthma randomised to received mepolizumab compared to placebo, with no significant increase in serious adverse events on treatment.

With regard to the secondary outcome measures, mepolizumab did not lead to a significant increase in measures of lung function ( $F E V_{1}$ or PEFR). There was no significant difference in asthma symptoms using an asthma symptom score or the

JACQ between IV mepolizumab at $250 \mathrm{mg}$ or $750 \mathrm{mg}$ and placebo. However, there was a significant difference between 75 mg IV mepolizumab and placebo (although a non-significant test for subgroup difference) and between SC mepolizumab and placebo, in participants with severe eosinophilic asthma. There were minimal significant adverse events related to mepolizumab, but headache and nasopharyngitis were commonly reported side effects. Due to the variety of dosing regimens and protocols, direct comparison of eosinophil counts in peripheral blood, sputum and bronchoalveolar fluid was not possible.

Peripheral blood eosinophil counts, sputum eosinophil counts and eosinophil counts in bronchoalveolar fluid all showed a significant reduction after treatment with mepolizumab.

There were only two studies that included paediatric patients, down to the age of 12 years old (Ortega 2014; Pavord 2012), 
but there was no separate reporting of results in adolescents, so we have insufficient evidence to undertake a subgroup analysis based on age.

\section{Overall completeness and applicability of evidence}

Although the precise definition of asthma exacerbation is subject to debate, with the consequent variability in reporting, it is nevertheless considered to be one of the core outcomes to be measured in asthma studies (Fuhlbrigge 2012). We found evidence of a reduction in the rate of clinically significant exacerbations in adults with severe eosinophilic asthma given IV or SC mepolizumab. Health-related quality of life (HRQoL) improved with intervention compared to placebo by a mean of seven units in the single study using SGRQ (Ortega 2014), but the mean change in AQLQ was less than the minimal clinically important difference and was not accompanied by responder analyses. These two primary outcomes are clinically important outcomes for the individual. Secondary outcomes of asthma symptoms scores, cough scores, lung function and airway hyperreactivity were not influenced by mepolizumab. Most studies examined eosinophils, inflammatory markers and mediators using a combination of peripheral blood, sputum and bronchoalveolar lavage and showed reductions in those who received mepolizumab. The clinical relevance of this finding to patients may not be clinically important. There were no studies in children under 12 and only two studies included children aged 12 years or older (but without disaggregating results for the participating adolescents). The asthma population examined in this review was too heterogeneous to draw any conclusions about the general asthma population.

\section{Quality of the evidence}

Using the GRADE system, we considered the quality of evidence for IV mepolizumab to be limited, as this is not a licenced delivery route (so we would regard this as indirect evidence). We felt that the HRQoL results were of moderate quality, and further research may have an important effect on the results presented. There was a risk of reporting bias in the assessment of HRQoL for one paper: Flood-Page 2007 noted no significant changes in HRQoL but did not provide any data, thus no data could be included in the meta-analysis. We are aware of the limitations in some of the studies and have detailed them in the results section, Figure 2 and Figure 3 . We determined that the risk of performance bias and detection bias based on the blinding processes was low in all eight studies. We also found that selection bias was low in only three studies for both random sequence generation and allocation concealment (Nair 2009; Ortega 2014; Pavord 2012) but unclear in four others ( Buttner 2003; Flood-Page 2003; Flood-Page 2007; Leckie 2000). Haldar 2009 had a low risk of bias for random sequence generation, but the risk of bias was unclear with respect to allocation concealment. Publication bias was not formally assessed through the construction of a funnel plot due to the small number of included studies. However, we performed a thorough search strategy, including searching conference abstracts and ongoing studies, in order to identify unpublished studies.

\section{Potential biases in the review process}

We acknowledge the potential for publication bias in this review, as it is possible that we failed to identify unpublished trials that may have provided positive or negative outcomes, which in turn could have altered the treatment benefits. However, to the best of our knowledge, we identified a significant number of trials meeting our inclusion criteria through comprehensive and systematic database searches. We tried to address any study selection bias by having two review authors who independently evaluated all the identified studies. We also ensured that the assessment of each trial was consistently in line with the inclusion criteria.

\section{Agreements and disagreements with other studies or reviews}

Our review follows on from Liu 2013, which also considered the efficacy of mepolizumab in patients with asthma. The present review includes one extra study (Ortega 2014), and its findings are consistent with Liu 2013. Both reviews highlight the need for further research in this area.

\section{Authors' conclusions}

\section{Implications for practice}

It is not possible to draw firm conclusions from this review with respect to the role of mepolizumab versus placebo in patients with asthma, due partly to the heterogeneity of the studies.

The currently available studies provide evidence that mepolizumab leads to an improvement in health-related quality of life scores and a reduction of asthma exacerbations in people with severe eosinophilic asthma (Haldar 2009; Nair 2009; Pavord 2012; Ortega 2014). There was also an improvement in asthma symptom scores in subjects with persistent eosinophilic asthma when using subcutaneous mepolizumab and $75 \mathrm{mg}$ mepolizumab intravenously (Ortega 2014). Mepolizumab did not lead to a significant increase in measures of lung function.

Further research is needed to clarify which subgroups of patients with asthma could potentially benefit from this treatment. Dosage, ideal dosing regimens and duration of treatment need to be clarified, as the studies included in this review differed in their protocols. There were only two studies that included children (over the age of 12), and these do not provide sufficient evidence on which to base a recommendation for use. At the present time, larger studies are required to establish the role of mepolizumab in the treatment of asthma.

\section{Implications for research}

There needs to be further research on mepolizumab in children, with a focus on the core outcomes of exacerbations and HRQoL but also asthma symptoms and lung function (in children who can perform respiratory function tests). 
exacerbations in participants with severe eosinophilic asthma. However, there needs to be further research to ascertain the optimum dose and regimen for mepolizumab therapy, as the studies included in this review used a wide range of dosing regimens.

\section{Acknowledgements}

We would particularly like to acknowledge the excellent support and assistance from Emma Welsh, Liz Stovold and Emma Jackson of the Cochrane Airways Review Group, together with the greatly appreciated guidance from Chris Cates (Cochrane Airways Review Group Co-ordinating Editor). The support provided by librarians Judith Scammel, Jane Appleton and Hilary Garrett at St George's University of London is also greatly appreciated.

We are very grateful to Chris Cates, the Contact Editor who commented critically on the review.

The information provided by Prof Peter Barnes regarding an included study (Leckie 2000) is also much appreciated. The background and methods section of this review is based on a standard template used by Cochrane Airways Group.

\section{Contributions of authors}

SM, KD, NW and CP contributed to the writing of the protocol. NW and CP independently selected trials for the review, NW and LB extracted the data, and KD entered the data into the RevMan file with cross-checking by SM. KD and SM wrote the Results section, and NW, LB, CP, KD and SM coauthored the Discussion and Conclusions.

\section{Declarations of interest}

None known.

\section{Differences between protocol and review}

We initially planned to use a fixed-effect model for meta-analysis, but we agreed with a peer reviewer who suggested that a random-effects model was more appropriate in view of the substantial clinical heterogeneity between the trials.

Although sufficient studies were not identified to conduct subgroup analyses, a posthoc subgroup analysis of dose of intervention was identified and included for use in a future version of this review.

We have included lung function and asthma symptoms in the summary of findings table as additional outcomes which we believe to be important to people making decisions about this intervention.

\section{Published notes}

\section{Characteristics of studies}

Characteristics of included studies

\section{Buttner 2003}


MEP-AST Mepolizumab versus placebo for asthma

\begin{tabular}{|l|l|}
\hline Methods & Randomised, placebo-controlled, parallel-group trial \\
\hline Participants & $\begin{array}{l}\text { Reported as: "Seven male and } 12 \text { female patients with mild or moderate asthma, aged } \\
20-59 \text { yrs (mean } 41 \text { yrs), with duration of disease between } 1-32 \text { yrs (mean } 11 \text { yrs) } \\
\text { were investigated. For inclusion, FEV } 1 \text { had to be from } 50 \text { to } 80 \% \text { of predicted at } \\
\text { baseline, with a reversibility of at least } 12 \% \text {. None of the patients suffered from } \\
\text { clinical exacerbation, and all patients were on a stable daily dose of up to } 1000 \text { mcg } \\
\text { beclomethasone dipropionate or a corresponding dose of other inhaled corticosteroids } \\
\text { for at least } 6 \text { weeks prior to the study. As a symptom reliever salbutamol was allowed if } \\
\text { needed. The detailed clinical characterisation of patients revealed no significant } \\
\text { difference between the study groups." } \\
5 \text { participants allocated to receive mepolizumab } 750 \text { mg, } 7 \text { to receive mepolizumab } \\
250 \text { mg and } 7 \text { to receive placebo. }\end{array}$ \\
\hline Interventions & $\begin{array}{l}1 \text { month run-in period to ensure stable disease } \\
3 \text { intravenous doses of either mepolizumab (750 mg), mepolizumab (250 mg) or } \\
\text { placebo every } 4 \text { weeks with a follow-up period of } 3 \text { months }\end{array}$ \\
\hline Outcomes & $\begin{array}{l}\text { Peripheral blood leukocytes, qualitative and quantitative distribution of eosinophils and } \\
\text { lymphocyte subpopulations, frequencies of IL-2, }-3,-4,-5,-10,-13, \text { interferon-C- } \\
\text { producing CD4 T-cells and serum eosinophil cationic protein (ECP) levels }\end{array}$ \\
\hline Notes & $\begin{array}{l}6-\text {-month multicentre trial in Germany } \\
\text { Supported in part by SmithKline Beecham, Harlow, UK }\end{array}$ \\
\hline
\end{tabular}

Risk of bias table

\begin{tabular}{|l|l|l|}
\hline $\begin{array}{l}\text { Bias } \\
\text { Random sequence generation } \\
\text { (selection bias) }\end{array}$ & Unthors' judgement & Support for judgement \\
\hline $\begin{array}{l}\text { Allocation concealment (selection } \\
\text { bias) }\end{array}$ & Unclear risk & Method of randomisation not reported \\
\hline $\begin{array}{l}\text { Blinding of participants and } \\
\text { personnel (performance bias) }\end{array}$ & Low risk & Reported as double blind \\
\hline $\begin{array}{l}\text { Blinding of outcome assessment } \\
\text { (detection bias) }\end{array}$ & Low risk & Reported as double blind \\
\hline $\begin{array}{l}\text { Incomplete outcome data (attrition } \\
\text { bias) }\end{array}$ & Unclear risk & Appears to be unreported \\
\hline Selective reporting (reporting bias) & Low risk & No apparent indication of reporting bias \\
\hline
\end{tabular}

Flood-Page 2003 
MEP-AST Mepolizumab versus placebo for asthma

\begin{tabular}{|c|c|}
\hline Methods & 2-centre, double-blind, placebo-controlled, parallel-group study \\
\hline Participants & $\begin{array}{l}\text { Reported as: "Twenty-four people with mild asthma, with a } \mathrm{FEV}_{1} \text { of } 70 \% \text { or more of } \\
\text { predicted. Participants were within an } 18 \text { - to } 55 \text {-year-old age range. All were atopic } \\
\text { (defined by a positive skin prick test to one or more aeroallergen), and all were well } \\
\text { controlled with short-acting 2-agonists, without corticosteroids or other anti- } \\
\text { inflammatory drugs in the preceding } 8 \text { weeks. } \\
\text { All participants had a clear history of asthma, demonstrated airway } \\
\text { hyperresponsiveness with a PC } 20 \text { to histamine of } 4.0 \mathrm{mg} / \mathrm{mL} \text { or less. All were } \\
\text { nonsmokers. Eleven participants received mepolizumab and } 13 \text { received placebo." } \\
\text { - Age: mepolizumab, median } 31 \text { years (range } 20 \text { to } 53 \text { ); placebo, median } 30 \text { years } \\
\text { (range } 20 \text { to } 52 \text { ) } \\
\text { - Males: mepolizumab, } 9 \text {; placebo, } 8 \\
\text { - Baseline morning PEFR, L/min: mepolizumab, median } 433 \text { (range } 358 \text { to } 585 \text { ); } \\
\text { - Basebo, median } 459.5 \text { (range } 368 \text { to } 490 \text { ) } \\
\text { median } 3.1 \text { (range } 1.8 \text { to } 5.25 \text { ) } \\
\text { - Baseline } \mathrm{FEV}_{1} \text {, \% predicted: mepolizumab, median } 87.0 \text { (range } 71 \text { to 109); placebo, } \\
\text { median } 80.0 \text { (range } 71 \text { to 106) }\end{array}$ \\
\hline Interventions & $\begin{array}{l}3 \text { Intravenous doses of either } 750 \mathrm{mg} \text { of mepolizumab or placebo over } 20 \text { weeks (at } \\
\text { weeks } 0,4 \text { and } 8 \text { ) }\end{array}$ \\
\hline Outcomes & $\begin{array}{l}\text { Airway eosinophils, bone marrow eosinophils, blood eosinophils, airway } \\
\text { hyperresponsiveness, } \mathrm{FEV}_{1} \text { and PEFR }\end{array}$ \\
\hline Notes & $\begin{array}{l}\text { 20-week study conducted at the Royal Brompton and London Chest Hospitals, London } \\
\text { UK. } \\
\text { Supported by GlaxoSmithKline. }\end{array}$ \\
\hline
\end{tabular}

Risk of bias table

\begin{tabular}{|l|l|l|}
\hline Bias & $\begin{array}{l}\text { Authors' } \\
\text { judgement }\end{array}$ & Support for judgement \\
\hline $\begin{array}{l}\text { Random sequence generation } \\
\text { (selection bias) }\end{array}$ & Unclear risk & Method of randomisation not reported \\
\hline $\begin{array}{l}\text { Allocation concealment (selection } \\
\text { bias) }\end{array}$ & Unclear risk & Method of randomisation not reported \\
\hline $\begin{array}{l}\text { Blinding of participants and } \\
\text { personnel (performance bias) }\end{array}$ & Low risk & Reported as double blind \\
\hline $\begin{array}{l}\text { Blinding of outcome assessment } \\
\text { (detection bias) }\end{array}$ & Low risk & Reported as double blind \\
\hline $\begin{array}{l}\text { Incomplete outcome data (attrition } \\
\text { bias) }\end{array}$ & Low risk & $\begin{array}{l}\text { All 24 volunteers completed the study without reporting adverse } \\
\text { events or asthma exacerbations }\end{array}$ \\
\hline Selective reporting (reporting bias) & Low risk & No apparent indication of reporting bias \\
\hline
\end{tabular}

Flood-Page 2007 
MEP-AST Mepolizumab versus placebo for asthma

\begin{tabular}{|c|c|}
\hline Methods & Multicentre, randomised, double-blind, placebo-controlled trial. \\
\hline Participants & 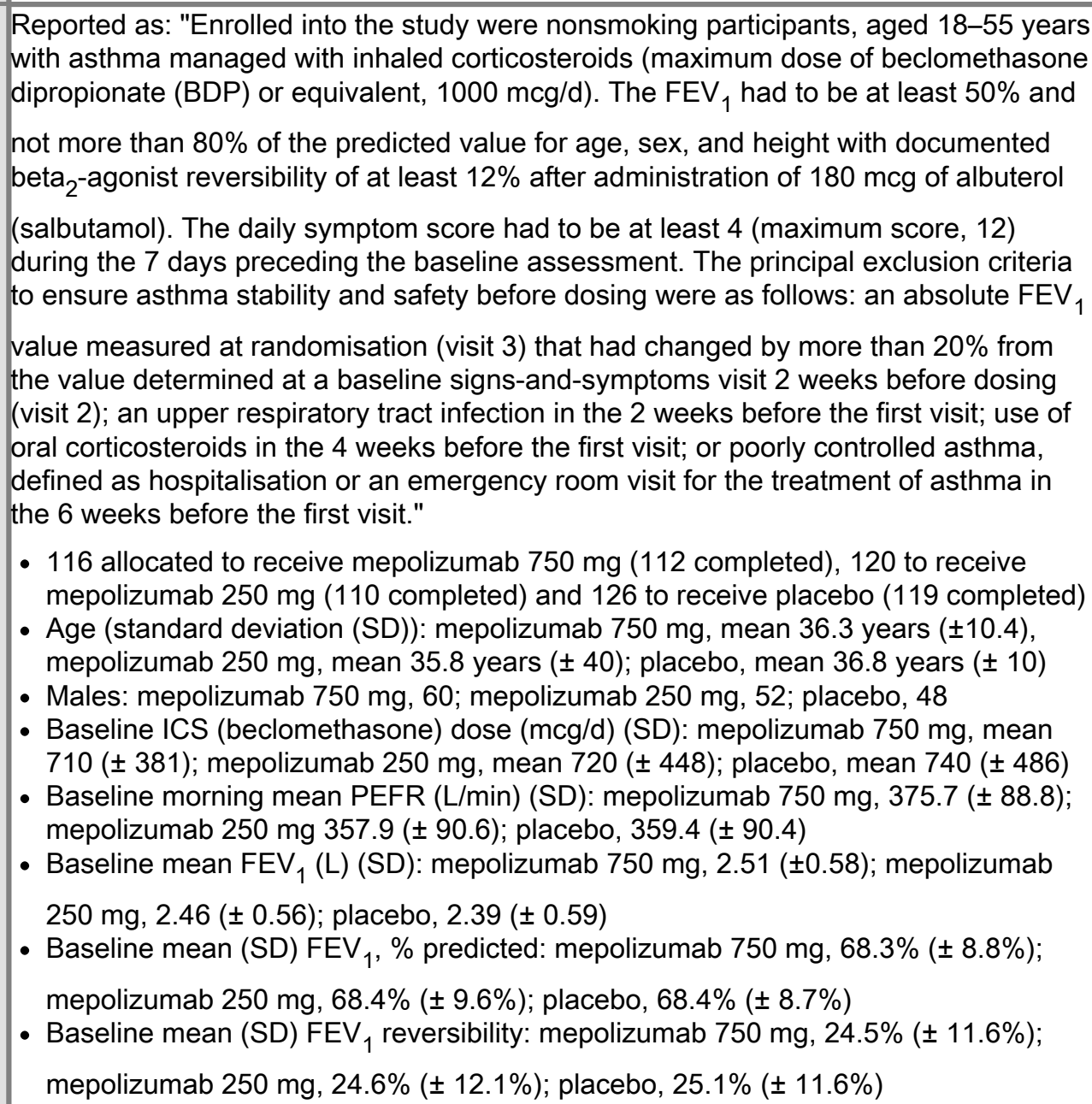 \\
\hline Interventions & $\begin{array}{l}\text { 4-week run-in period to ensure stable disease } \\
3 \text { intravenous doses of mepolizumab }(750 \mathrm{mg}) \text {, mepolizumab }(250 \mathrm{mg}) \text { or placebo (at } \\
\text { weeks } 0,4 \text { and } 8)\end{array}$ \\
\hline Outcomes & $\begin{array}{l}\text { Reported as: "The primary efficacy variable was the change from baseline in } \\
\text { domiciliary morning peak expiratory flow rate (PEFR) recorded at weeks } 12 \text { and } 20 . \\
\text { This was recorded as the mean PEFR over the } 7 \text { days preceding the treatment period } \\
\text { (baseline value) and preceding weeks } 12 \text { and } 20 \text {. The secondary efficacy variables } \\
\text { were the changes from baseline of } \mathrm{FEV}_{1} \text {, asthma summary symptom scores (the total } \\
\text { of the daytime asthma, nighttime asthma, and morning asthma scores), use of rescue } \\
\text { medication such as albuterol (salbutamol), quality of life scores, asthma exacerbation } \\
\text { rates, and eosinophil counts in blood and sputum." }\end{array}$ \\
\hline Notes & $\begin{array}{l}\text { 20-week multicentre trial at } 55 \text { centres in } 5 \text { countries (France, Germany, Netherlands, } \\
\text { the UK, and the USA) } \\
\text { Supported by GlaxoSmithKline. }\end{array}$ \\
\hline
\end{tabular}

Risk of bias table 
MEP-AST Mepolizumab versus placebo for asthma

\begin{tabular}{|c|c|c|}
\hline Bias & \begin{tabular}{|l} 
Authors' \\
judgement
\end{tabular} & Support for judgement \\
\hline $\begin{array}{l}\text { Random sequence generation } \\
\text { (selection bias) }\end{array}$ & $\begin{array}{l}\text { Unclear } \\
\text { risk }\end{array}$ & Method of randomisation not reported \\
\hline $\begin{array}{l}\text { Allocation concealment (selection } \\
\text { bias) }\end{array}$ & $\begin{array}{l}\text { Unclear } \\
\text { risk }\end{array}$ & Method of randomisation not reported \\
\hline $\begin{array}{l}\text { Blinding of participants and } \\
\text { personnel (performance bias) }\end{array}$ & Low risk & Reported as double blind \\
\hline $\begin{array}{l}\text { Blinding of outcome assessment } \\
\text { (detection bias) }\end{array}$ & Low risk & Reported as double blind \\
\hline $\begin{array}{l}\text { Incomplete outcome data (attrition } \\
\text { bias) }\end{array}$ & Low risk & $\begin{array}{l}\text { Reported as: "Of the } 362 \text { patients randomised into the study, a total of } 21 \\
\text { patients (5.8\%) were withdrawn. The percentage of patients completing the } \\
\text { study was high for all treatment arms. The most common reason for } \\
\text { withdrawal during the study was adverse experience }(n=10 ; 2.8 \%) \text {. The } \\
\text { percentage of patients who were withdrawn because of adverse } \\
\text { experiences was higher among patients receiving placebo }(4.0 \%) \text { and } \\
\text { mepolizumab at } 250 \mathrm{mg}(3.3 \%) \text { compared with patients receiving } \\
\text { mepolizumab at } 750 \mathrm{mg}(0.9 \%) \text {. A total of } 37 \text { patients were randomised to } \\
\text { the induced sputum arm of the study, and } 3 \text { patients were subsequently } \\
\text { withdrawn." }\end{array}$ \\
\hline Selective reporting (reporting bias) & High risk & No significant difference in HRQoL and did not provide any data \\
\hline
\end{tabular}

Haldar 2009 
MEP-AST Mepolizumab versus placebo for asthma

\begin{tabular}{|c|c|}
\hline Methods & Randomised, double-blind, placebo-controlled, parallel-group trial \\
\hline Participants & $\begin{array}{l}\text { Participants had refractory eosinophilic asthma and a history of recurrent severe } \\
\text { exacerbations. } \\
\text { Reported as: "Inclusion criteria were a diagnosis of refractory asthma according to } \\
\text { American Thoracic Society criteria, a sputum eosinophil percentage of more than } 3 \% \\
\text { on at least one occasion in the previous } 2 \text { years despite high-dose corticosteroid } \\
\text { treatment, and at least two exacerbations requiring rescue prednisolone treatment in } \\
\text { the previous } 12 \text { months. Additional criteria for inclusion were stable treatment } \\
\text { requirements and an absence of exacerbations for more than } 6 \text { weeks before } \\
\text { enrolment in the study. Exclusion criteria were current smoking, serologic evidence of } \\
\text { a parasitic infection, a serious coexisting illness, the possibility of conception, and poor } \\
\text { adherence to treatment." } \\
\text { - Age: mepolixumab, mean } 48 \text { (range from } 21 \text { to } 63 \text { ); placebo, mean } 50 \text { (range from } \\
24 \text { to } 72 \text { ) } \\
\text { - Males: mepolixumab, } 14 ; \text { placebo, } 18 \\
\text { - Baseline mean (SD) FEV } 1, \% \text { predicted after bronchodilator use: mepolizumab, } \\
78.1 \%( \pm 20.9 \%) ; \text { placebo, } 77.6 \% \text { ( } \pm 24.1 \% \text { ) } \\
\text { - Baseline mean (SD) FEV } / F V C \text { ratio: mepolizumab, } 72.2 \% \text { ( } \pm 9.6 \% \text { ), placebo, } \\
67.7 \% \text { ( } \pm 13.5 \%) \\
\text { - } 29 \text { allocated to receive mepolizumab } 750 \text { mg, } 32 \text { to receive placebo }\end{array}$ \\
\hline Interventions & $\begin{array}{l}\text { Intravenous mepolizumab }(750 \mathrm{mg}) \text { versus matched placebo ( } 150 \mathrm{~mL} \text { of } 0.9 \% \text { saline) } \\
\text { at monthly intervals for } 1 \text { year }\end{array}$ \\
\hline Outcomes & $\begin{array}{l}\text { Reported as: "[P]rimary outcome measure was the number of severe exacerbations } \\
\text { per subject during the } 50 \text {-week treatment phase. Secondary outcomes included a } \\
\text { change in asthma symptoms, scores on the Asthma Quality of Life Questionnaire } \\
\text { (AQLQ, in which scores range from } 1 \text { to } 7 \text {, with lower values indicating more severe } \\
\text { impairment } \\
\text { and a change of } 0.5 \text { unit considered to be clinically important), forced expiratory } \\
\text { volume in } 1 \text { second }\left(\mathrm{FEV}_{1}\right) \text { after use of a bronchodilator, airway hyperresponsiveness, } \\
\text { and eosinophil counts in the blood and sputum." }\end{array}$ \\
\hline Notes & $\begin{array}{l}\text { Single centre trial conducted at Institute for Lung Health, Leicester, UK } \\
\text { Supported by GlaxoSmithKline }\end{array}$ \\
\hline
\end{tabular}

Risk of bias table 
MEP-AST Mepolizumab versus placebo for asthma

\begin{tabular}{|c|c|c|}
\hline Bias & $\begin{array}{l}\text { Authors' } \\
\text { judgement }\end{array}$ & Support for judgement \\
\hline $\begin{array}{l}\text { Random sequence generation } \\
\text { (selection bias) }\end{array}$ & Low risk & $\begin{array}{l}\text { Reported as: "Stratified randomisation with use of the minimisation } \\
\text { method, which was performed by } \\
\text { an independent clinician. Participants were randomly assigned with the use } \\
\text { of the minimisation method to receive } 12 \text { infusions of either } 750 \mathrm{mg} \text { of } \\
\text { mepolizumab delivered intravenously or matched placebo ( } 150 \mathrm{~mL} \text { of } 0.9 \% \\
\text { saline) at monthly intervals between visits } 3 \text { and } 14 \text {. The criteria used for } \\
\text { minimisation were the frequency of exacerbations in the previous } 12 \\
\text { months, the baseline eosinophil count in the sputum and the number of } \\
\text { participants taking oral corticosteroids." }\end{array}$ \\
\hline $\begin{array}{l}\text { Allocation concealment (selection } \\
\text { bias) }\end{array}$ & $\begin{array}{l}\text { Unclear } \\
\text { risk }\end{array}$ & Details not reported \\
\hline $\begin{array}{l}\text { Blinding of participants and } \\
\text { personnel (performance bias) }\end{array}$ & Low risk & Reported as double blind \\
\hline $\begin{array}{l}\text { Blinding of outcome assessment } \\
\text { (detection bias) }\end{array}$ & Low risk & Reported as double blind \\
\hline $\begin{array}{l}\text { Incomplete outcome data (attrition } \\
\text { bias) }\end{array}$ & Low risk & $\begin{array}{l}\text { Reported as: "A total of } 61 \text { of the } 63 \text { participants ( one required and } \\
\text { operation and one withdrew consent) who were screened started treatment } \\
\text { and constituted the modified intention-to-treat population. Thirty-two } \\
\text { participants were randomly assigned to receive placebo. Overall, } 94.9 \% \text { of } \\
\text { treatment visits were completed. Participants who withdrew completed a } \\
\text { mean of } 4.6 \text { treatment visits (38.3\%)." }\end{array}$ \\
\hline Selective reporting (reporting bias) & Low risk & No apparent indication of reporting bias \\
\hline
\end{tabular}

Leckie 2000 
MEP-AST Mepolizumab versus placebo for asthma

\begin{tabular}{|c|c|}
\hline Methods & Randomised, double-blind, placebo-controlled trial \\
\hline Participants & 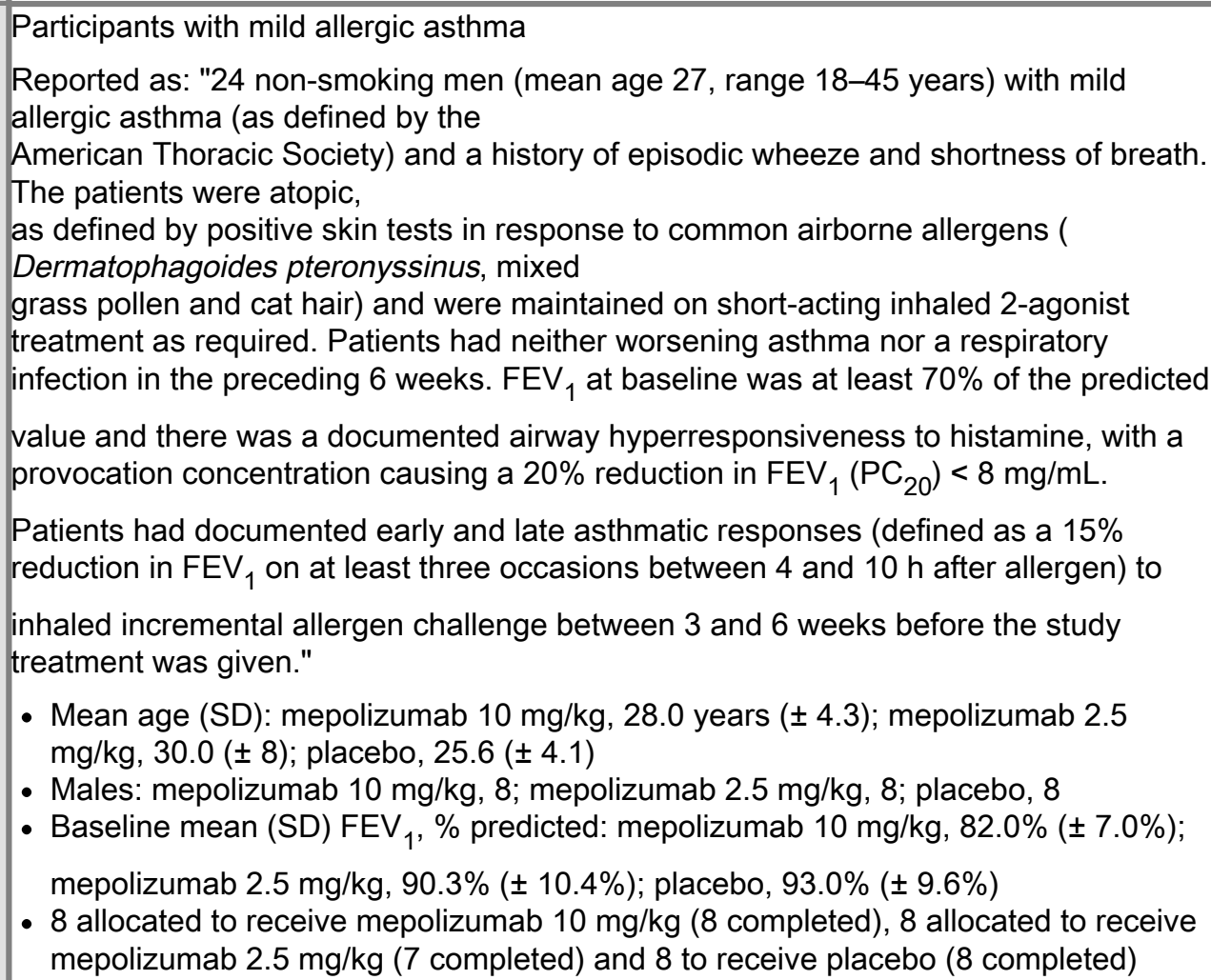 \\
\hline Interventions & Mepolizumab 10 mg/kg versus mepolizumab 2.5 mg/kg versus placebo \\
\hline Outcomes & $\begin{array}{l}\text { Blood eosinophils, sputum eosinophils, histamine } \mathrm{PC}_{20}(\mathrm{mg} / \mathrm{mL} \text { ), late asthmatic } \\
\text { reaction (maximum \% fall in } \mathrm{FEV}_{1} \text { ) }\end{array}$ \\
\hline Notes & $\begin{array}{l}16 \text { week study conducted at } 3 \text { centres: Imperial College London, Southampton } \\
\text { University and University of Amsterdam } \\
\text { Supported by SmithKline Beecham, UK }\end{array}$ \\
\hline
\end{tabular}

Risk of bias table

\begin{tabular}{|l|l|l|}
\hline Bias & Authors' judgement & Support for judgement \\
\hline $\begin{array}{l}\text { Random sequence generation } \\
\text { (selection bias) }\end{array}$ & Unclear risk & Method of randomisation not reported \\
\hline $\begin{array}{l}\text { Allocation concealment (selection } \\
\text { bias) }\end{array}$ & Unclear risk & Method of randomisation not reported \\
\hline $\begin{array}{l}\text { Blinding of participants and } \\
\text { personnel (performance bias) }\end{array}$ & Low risk & Study reported as double blind \\
\hline $\begin{array}{l}\text { Blinding of outcome assessment } \\
\text { (detection bias) }\end{array}$ & Low risk & Study reported as double blind \\
\hline $\begin{array}{l}\text { Incomplete outcome data (attrition } \\
\text { bias) }\end{array}$ & Low risk & 1 subject lost to follow-up, all other data appears to be reported \\
\hline Selective reporting (reporting bias) & Low risk & No apparent indication of reporting bias \\
\hline
\end{tabular}

Nair 2009

\begin{tabular}{|l|l|}
\hline Methods & Randomised, double-blind, placebo-controlled trial \\
\hline
\end{tabular}




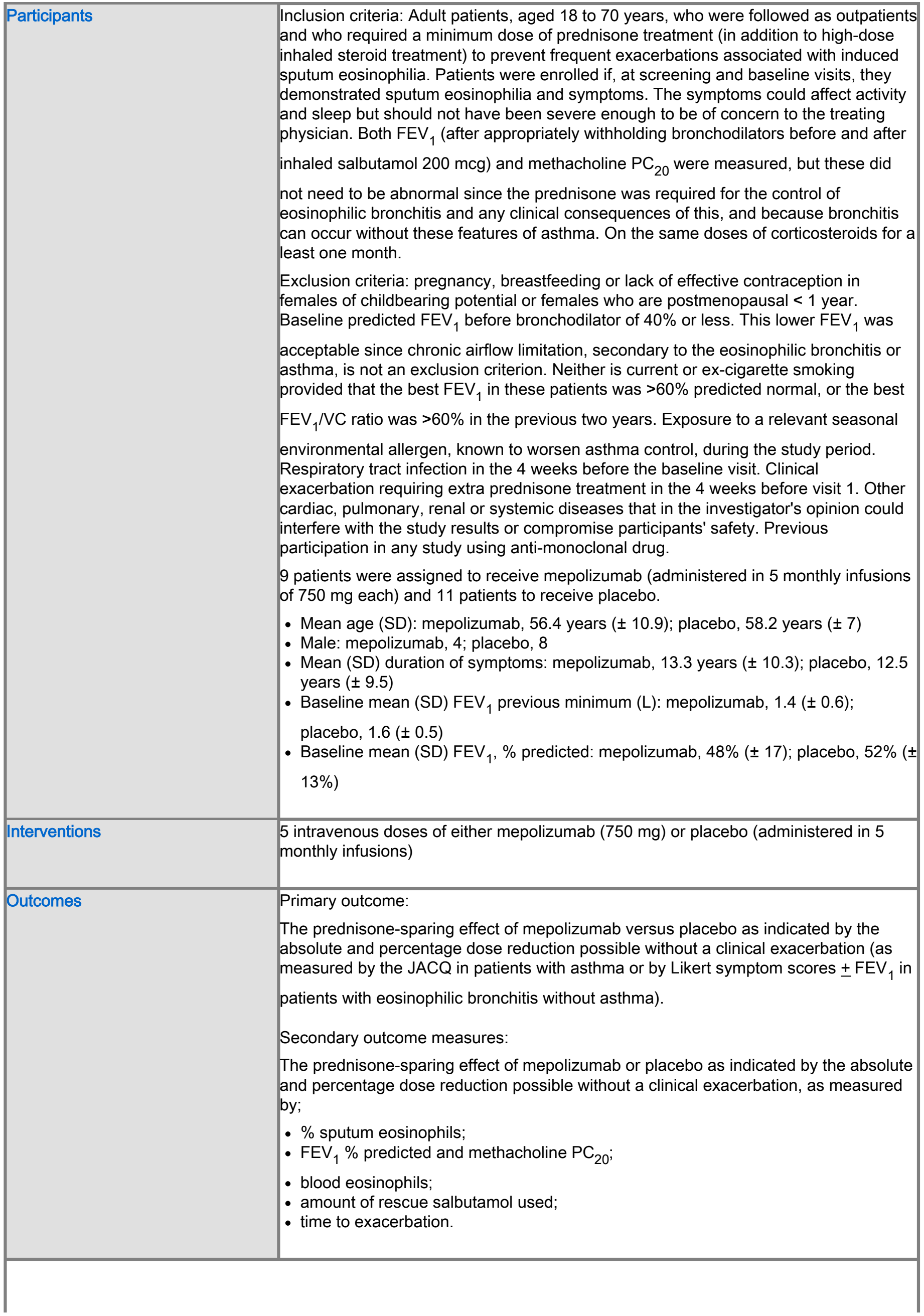


MEP-AST Mepolizumab versus placebo for asthma

\begin{tabular}{|l|l|}
\hline Notes & $\begin{array}{l}\text { 26-week trial at Firestone Institute for Respiratory Health, St. Joseph's Healthcare and } \\
\text { Department of Medicine, McMaster University, Hamilton, ON, Canada } \\
\text { Supported by an unrestricted educational grant from GlaxoSmithKline }\end{array}$ \\
\hline
\end{tabular}

Risk of bias table

\begin{tabular}{|c|c|c|}
\hline Bias & $\begin{array}{l}\text { Authors' } \\
\text { judgement }\end{array}$ & Support for judgement \\
\hline $\begin{array}{l}\text { Random sequence generation } \\
\text { (selection bias) }\end{array}$ & Low risk & $\begin{array}{l}\text { Computer-generated randomisation codes stratified patients into two } \\
\text { groups of } 10 \text { according to the daily dose of prednisone they were receiving } \\
\text { at the time of enrolment }(<10 \mathrm{mg} \text { or } \geq 10 \mathrm{mg} \text { ). Within each of the two } \\
\text { groups, patients were equally divided among those receiving mepolizumab } \\
\text { and those receiving placebo. When either group was filled, no additional } \\
\text { patients were recruited for that group. }\end{array}$ \\
\hline $\begin{array}{l}\text { Allocation concealment (selection } \\
\text { bias) }\end{array}$ & Low risk & $\begin{array}{l}\text { Randomisation codes were held by the pharmacy department, whose } \\
\text { members were unaware of clinical details in the study groups. }\end{array}$ \\
\hline $\begin{array}{l}\text { Blinding of participants and } \\
\text { personnel (performance bias) }\end{array}$ & Low risk & Reported as double blind \\
\hline $\begin{array}{l}\text { Blinding of outcome assessment } \\
\text { (detection bias) }\end{array}$ & Low risk & Reported as double blind \\
\hline $\begin{array}{l}\text { Incomplete outcome data (attrition } \\
\text { bias) }\end{array}$ & Low risk & $\begin{array}{l}\text { Two of the patients were included in the study in error and were therefore } \\
\text { excluded from some but not all of the analyses before the randomisation } \\
\text { code was broken }\end{array}$ \\
\hline Selective reporting (reporting bias) & Low risk & No apparent indication of reporting bias \\
\hline
\end{tabular}

Ortega 2014

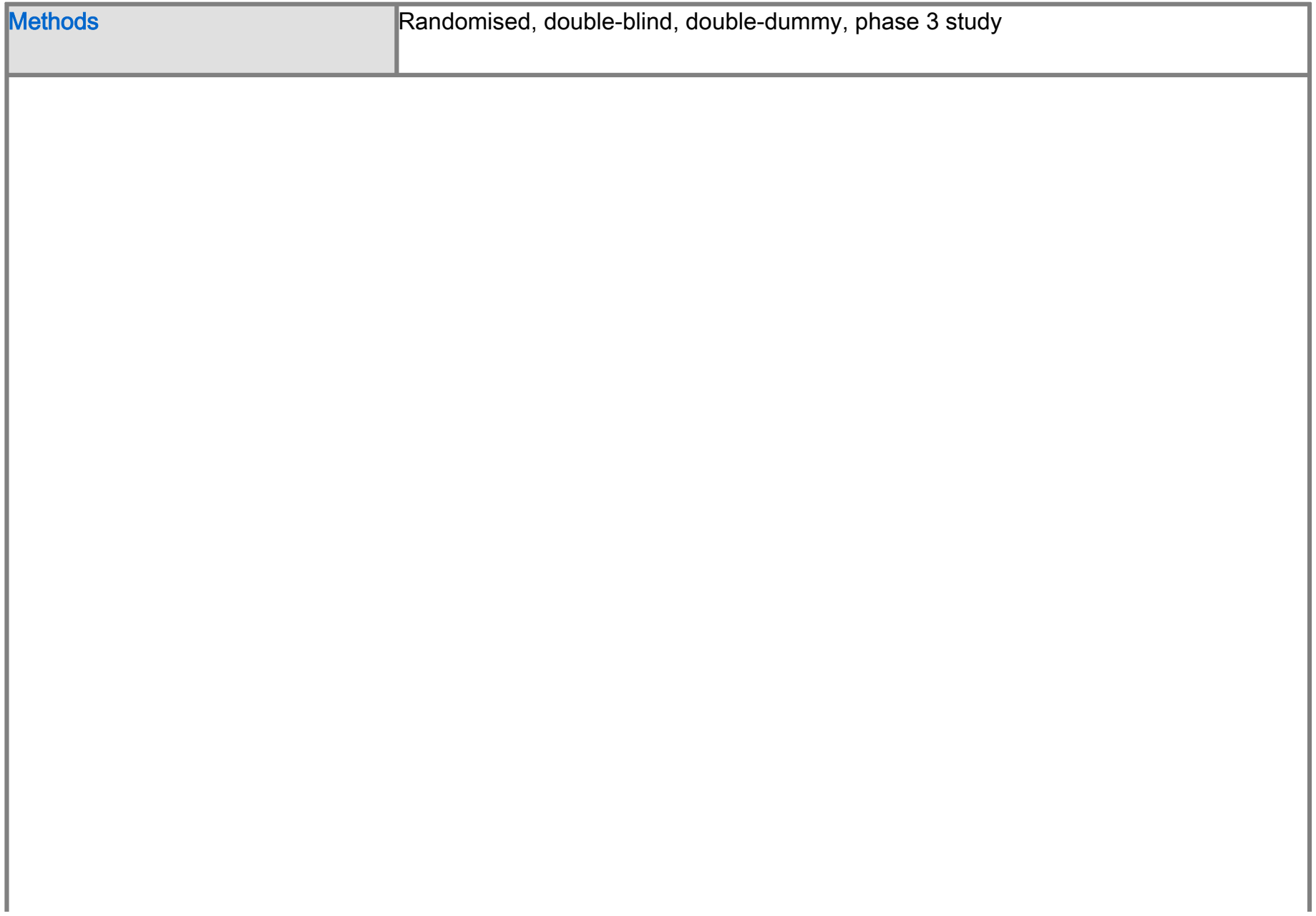




\begin{tabular}{|c|c|}
\hline Participants & 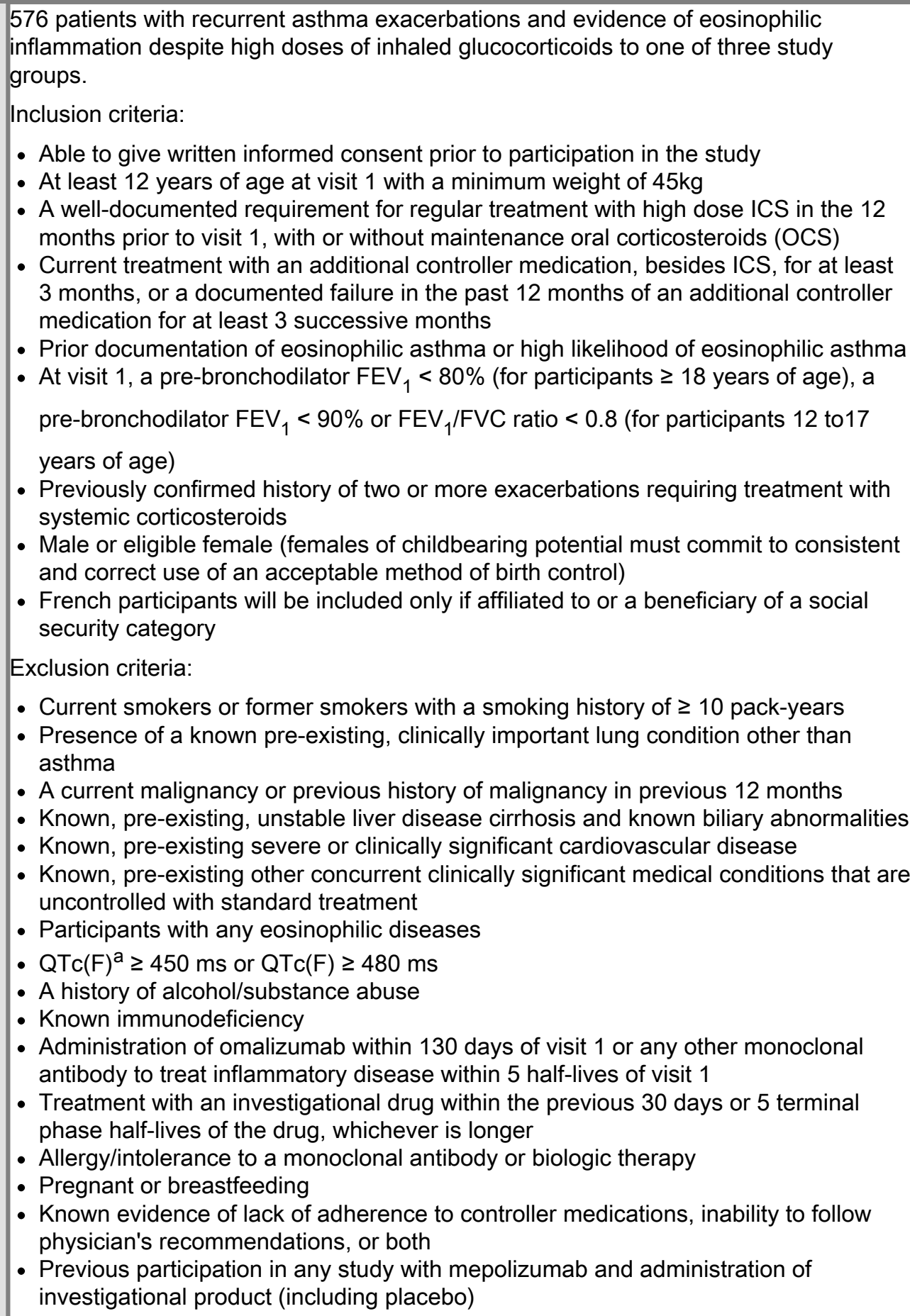 \\
\hline Interventions & $\begin{array}{l}\text { Mepolizumab in a } 75 \mathrm{mg} \text { intravenous dose versus mepolizumab in a } 100 \mathrm{mg} \\
\text { subcutaneous dose versus placebo every } 4 \text { weeks for } 32 \text { weeks }\end{array}$ \\
\hline Outcomes & $\begin{array}{l}\text { Primary outcome: } \\
\text { - Number of clinically significant exacerbations of asthma per year } \\
\text { Secondary outcomes: } \\
\text { - Number of clinically significant exacerbations requiring hospitalisation (including } \\
\text { intubation and admittance to an intensive care unit ) or ED visits per year } \\
\text { - Mean change from baseline in clinic pre-bronchodilator } \mathrm{FEV}_{1} \text { at week } 32 \\
\text { - Mean change from baseline in the SGRQ total score at week } 32\end{array}$ \\
\hline Notes & $\begin{array}{l}\text { 32-week treatment intervention, with } 1 \text { to } 6 \text { weeks run-in and 8-week followup. } \\
\text { Conducted in Baltimore, Middlesex, Ghent, Vancouver, Parma, Marseille and Paris }\end{array}$ \\
\hline
\end{tabular}


MEP-AST Mepolizumab versus placebo for asthma

Risk of bias table

\begin{tabular}{|l|l|l|}
\hline Bias & $\begin{array}{l}\text { Authors' } \\
\text { judgement }\end{array}$ & Support for judgement \\
\hline $\begin{array}{l}\text { Random sequence generation } \\
\text { (selection bias) }\end{array}$ & Low risk & Centralised computer-generated permuted block schedule \\
\hline $\begin{array}{l}\text { Allocation concealment (selection } \\
\text { bias) }\end{array}$ & Low risk & Treatment allocations will be concealed via the RandAll system \\
\hline $\begin{array}{l}\text { Blinding of participants and } \\
\text { personnel (performance bias) }\end{array}$ & Low risk & $\begin{array}{l}\text { Mepolizumab and placebo were identical in appearance and were } \\
\text { administered by a staff member who was unaware of the study group } \\
\text { assignments. }\end{array}$ \\
\hline $\begin{array}{l}\text { Blinding of outcome assessment } \\
\text { (detection bias) }\end{array}$ & Low risk & $\begin{array}{l}\text { The study drugs were prepared by staff members who were aware of } \\
\text { the study group assignments but were not involved in study } \\
\text { assessments. }\end{array}$ \\
\hline $\begin{array}{l}\text { Incomplete outcome data (attrition } \\
\text { bias) }\end{array}$ & Low risk & $6 \%$ (placebo), 8\% (IV), 5\% ( SC) did not complete the study \\
\hline Selective reporting (reporting bias) & Low risk & All outcome measures reported \\
\hline
\end{tabular}

Pavord 2012

\begin{tabular}{|l|l|}
\hline Methods & Multicentre, double-blind, placebo-controlled trial \\
\hline
\end{tabular}




\begin{tabular}{|c|c|}
\hline Participants & 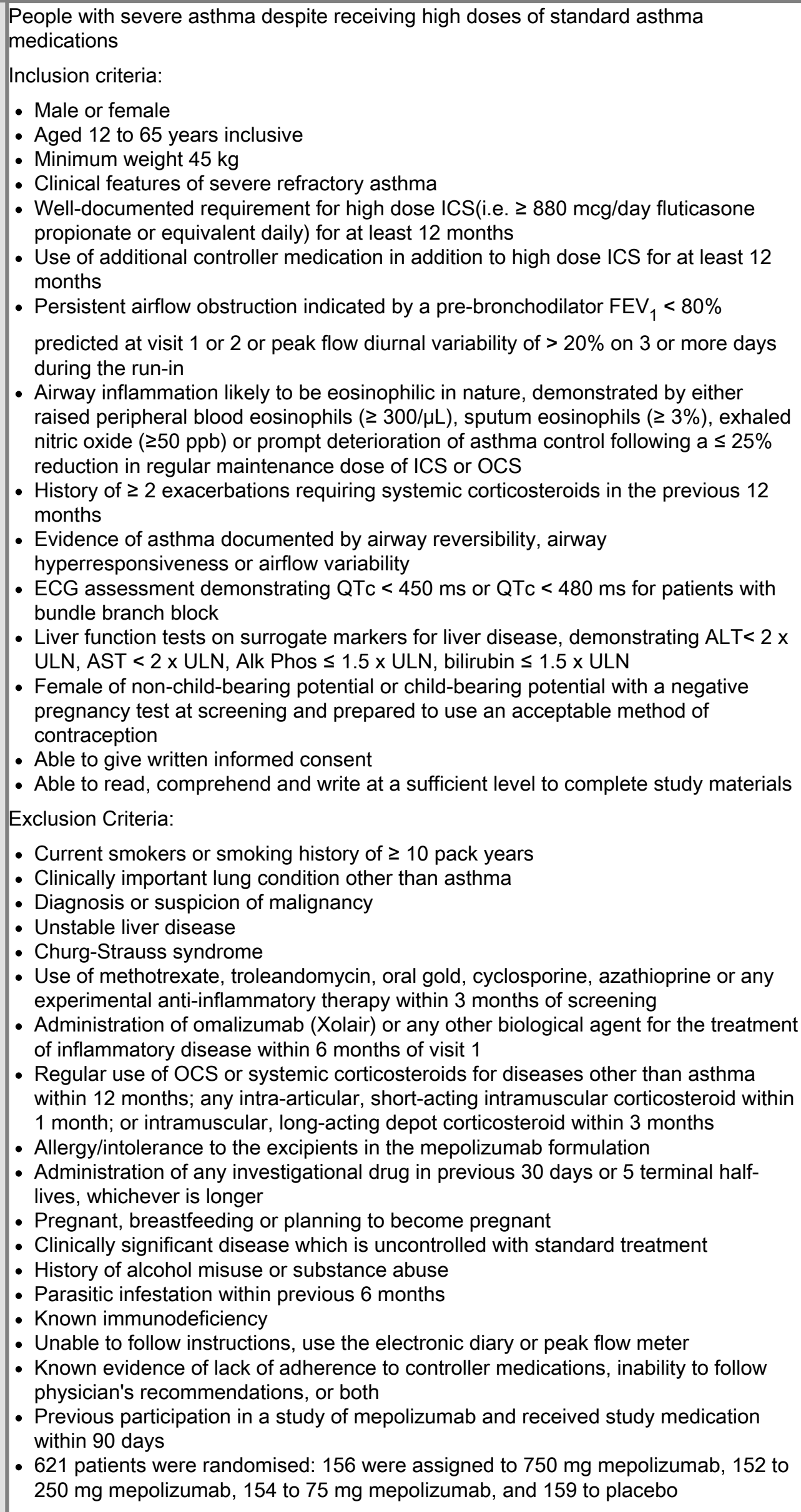 \\
\hline Interventions & $\begin{array}{l}13 \text { total intravenous infusions of mepolizumab }(750 \mathrm{mg}) \text {, mepolizumab (250 mg), } \\
\text { mepolizumab ( } 75 \mathrm{mg}) \text { or placebo given every } 4 \text { weeks }\end{array}$ \\
\hline
\end{tabular}


MEP-AST Mepolizumab versus placebo for asthma

\begin{tabular}{|l|l|}
\hline Outcomes & Primary outcome: \\
- Frequency of clinically significant exacerbations of asthma \\
Secondary outcomes: \\
- Time to first clinically significant exacerbation requiring oral or systemic \\
corticosteroids, hospitalisation, and/or ED visits \\
- Frequency of exacerbations requiring hospitalisation (including intubation and \\
admittance to an ICU) or ED visits \\
- Time to first exacerbation requiring hospitalisation or ED visit \\
- Frequency of investigator-defined exacerbations \\
- Time to first investigator-defined exacerbation \\
- Mean change from baseline in clinic pre-bronchodilator FEV ${ }_{1}$ over the 52-week \\
treatment period \\
- Mean change from baseline in clinic post-bronchodilator FEV ${ }_{1}$ over the 52-week \\
treatment period \\
- Mean change from baseline in ACQ score
\end{tabular}

Risk of bias table

\begin{tabular}{|c|c|c|}
\hline Bias & \begin{tabular}{|l} 
Authors' \\
judgement
\end{tabular} & Support for judgement \\
\hline $\begin{array}{l}\text { Random sequence generation } \\
\text { (selection bias) }\end{array}$ & Low risk & $\begin{array}{l}\text { Central telephone-based system and computer-generated randomly } \\
\text { permuted block schedule stratified by whether treatment with oral } \\
\text { corticosteroids was required }\end{array}$ \\
\hline $\begin{array}{l}\text { Allocation concealment (selection } \\
\text { bias) }\end{array}$ & Low risk & $\begin{array}{l}\text { Mepolizumab and placebo were prepared by unmasked site staff who } \\
\text { were not involved in study assessments }\end{array}$ \\
\hline $\begin{array}{l}\text { Blinding of participants and } \\
\text { personnel (performance bias) }\end{array}$ & Low risk & $\begin{array}{l}\text { Mepolizumab and placebo were prepared by unmasked site staff who } \\
\text { were not involved in study assessments. Both treatments were identical } \\
\text { in appearance and were given to patients by a masked member of the } \\
\text { site staff }\end{array}$ \\
\hline $\begin{array}{l}\text { Blinding of outcome assessment } \\
\text { (detection bias) }\end{array}$ & Low risk & Data analysts were masked to treatment allocation \\
\hline $\begin{array}{l}\text { Incomplete outcome data (attrition } \\
\text { bias) }\end{array}$ & Low risk & $\begin{array}{l}\text { All patients accounted for with information on reasons for having } \\
\text { withdrawn. Some patients not included in results due to 'poor efficacy' }\end{array}$ \\
\hline Selective reporting (reporting bias) & Low risk & No apparent indication of reporting bias \\
\hline
\end{tabular}

\section{Footnotes}

ACQ: Asthma Control Questionnaire; ALT: alanine aminotransferase; Alk Phos: alkaline phosphatase; AQLQ: Asthma Quality of Life Questionnaire; AST: aspartate aminotransferase; ECP: eosinophil cationic protein; ED: emergency department; FEV $_{1}$ : Forced expiratory volume in 1 second; FVC: forced vital capacity; HRQoL: health-related quality of life;

ICS: inhaled corticosteroid; IL: interleukin; IV: intravenous; JACQ: Juniper Asthma Control Questionnaire; OCS: oral corticosteroids; $\mathrm{PC}_{20}$ : histamine provocative concentration causing a $20 \%$ drop in $\mathrm{FEV}$; PEFR: peak expiratory flow rate;

SC: subcutaneous; SD: standard deviation; SGRQ: St. George's Respiratory Questionnaire; ULN: Upper Limit of Normal; VC: vital capacity.

${ }^{a} \mathrm{QTC}(\mathrm{F})$ : a measure of the time between the start of the $Q$ wave and the end of the T wave in the heart's electrical cycle, corrected for the heart rate using Fredericia's formula.

\section{Characteristics of excluded studies}

\section{Alvarez-Cuesta 1994}


MEP-AST Mepolizumab versus placebo for asthma

\begin{tabular}{|l|l|}
\hline Reason for exclusion & Study does not include mepolizumab \\
\hline
\end{tabular}

\section{Armentia 1992}

\begin{tabular}{l|l}
\hline Reason for exclusion & Study does not include mepolizumab
\end{tabular}

\section{Ayres 2004}

Reason for exclusion $\quad$ Study does not include mepolizumab

\section{Bel 2014}

Reason for exclusion Focus of trial is on steroid reduction and therefore does not meet our predefined inclusion criteria

\section{Berger 2003}

\begin{tabular}{|l|l}
\hline Reason for exclusion $\quad$ Study does not include mepolizumab \\
\hline
\end{tabular}

\section{Blanken 2012}

\begin{tabular}{|l|l|}
\hline Reason for exclusion $\quad$ Study does not include mepolizumab & \\
\hline
\end{tabular}

\section{Blanken 2013}

Reason for exclusion
Study does not include mepolizumab

Boulet 1997

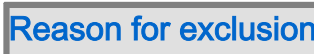
Study does not include mepolizumab

Bousquet 2004

\begin{tabular}{|l|l|}
\hline Reason for exclusion & Study does not include mepolizumab \\
\hline
\end{tabular}

\section{Bousquet 2011}

\begin{tabular}{|l|l|}
\hline Reason for exclusion & Study does not include mepolizumab \\
\hline
\end{tabular}

\section{Brown 2007}

\begin{tabular}{|l|l|}
\hline Reason for exclusion & Study does not include mepolizumab
\end{tabular}

\section{Bryant 1975}

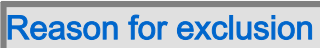
Study does not include mepolizumab

Bryant 1975a

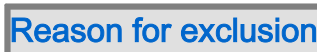
Study does not include mepolizumab

\section{Buhl 2000a}


MEP-AST Mepolizumab versus placebo for asthma

\begin{tabular}{|l|l|}
\hline Reason for exclusion & Study does not include mepolizumab \\
\hline
\end{tabular}

\section{Buhl 2002}

\begin{tabular}{|l|l}
\hline Reason for exclusion $\quad$ Study does not include mepolizumab \\
\hline
\end{tabular}

\section{Bush 1985}

\begin{tabular}{|l|l|}
\hline Reason for exclusion & Study does not include mepolizumab \\
\hline
\end{tabular}

\section{Busse 2001}

Reason for exclusion

\section{Busse 2008}

Reason for exclusion

$$
\text { Study does not include mepolizumab }
$$

\section{Caffarelli 2000}

\begin{tabular}{|l|l|}
\hline Reason for exclusion & Study does not include mepolizumab \\
\hline
\end{tabular}

\section{Castro 2010}

\begin{tabular}{|l|l|}
\hline Reason for exclusion & Does not include Mepolizumab \\
\hline
\end{tabular}

\section{Castro 2011}

\begin{tabular}{|l|l}
\hline Reason for exclusion & Does not include Mepolizumab
\end{tabular}

\section{Chandra 1989}

Reason for exclusion Study does not include mepolizumab

Chervinsky 2003

Reason for exclusion

Study does not include mepolizumab

\section{Clavel 1998}

\begin{tabular}{|l|l|}
\hline Reason for exclusion & Study does not include mepolizumab \\
\hline
\end{tabular}

\section{Corren 2003}

\begin{tabular}{|l|l|}
\hline Reason for exclusion & Study does not include mepolizumab
\end{tabular}

Corren 2010

Reason for exclusion

Cullell-Young 2002

Reason for exclusion

\section{De Boever 2014}

Reason for exclusion
Study does not include mepolizumab Study does not include mepolizumab Study does not include mepolizumab 
MEP-AST Mepolizumab versus placebo for asthma

Djukanovic 2004

Reason for exclusion

Study does not include mepolizumab

\section{Ebner 1989}

Reason for exclusion

Study does not include mepolizumab

Eckman 2010

Reason for exclusion

Study does not include mepolizumab

El-Nawawy 2000

Reason for exclusion

Study does not include mepolizumab

Fahy 1997

\begin{tabular}{|l|l}
\hline Reason for exclusion & Study does not include mepolizumab
\end{tabular}

Fahy 1999

Reason for exclusion

Study does not include mepolizumab

Finn 2003

Reason for exclusion

Study does not include mepolizumab

Frew 1998

\begin{tabular}{|l|l}
\hline Reason for exclusion $\quad$ Study does not include mepolizumab \\
\hline
\end{tabular}

Garcia 2013

\begin{tabular}{|l|l|}
\hline Reason for exclusion & Study does not include mepolizumab \\
\hline
\end{tabular}

Gauvreau 2011

\begin{tabular}{|l|l}
\hline Reason for exclusion $\quad$ Study does not include mepolizumab \\
\hline
\end{tabular}

Gauvreau 2014a

Reason for exclusion

Study does not include mepolizumab

Gauvreau $2014 b$

Reason for exclusion

Study does not include mepolizumab

Gauvreau 2014c

Reason for exclusion

Study does not include mepolizumab

Gevaert 2013

Reason for exclusion

Study does not include mepolizumab

Gordon 1972 
MEP-AST Mepolizumab versus placebo for asthma

\begin{tabular}{|l|l|}
\hline Reason for exclusion & Study does not include mepolizumab \\
\hline
\end{tabular}

Greenberg 1991

\begin{tabular}{|l|l}
\hline Reason for exclusion & Study does not include mepolizumab
\end{tabular}

Han 2009

\begin{tabular}{|l|l|}
\hline Reason for exclusion $\quad$ Study does not include mepolizumab & \\
\hline
\end{tabular}

Hanania 2011

Reason for exclusion $\quad$ Study does not include mepolizumab

Hanania 2013

\begin{tabular}{|l|l}
\hline Reason for exclusion $\quad$ Study does not include mepolizumab \\
\hline
\end{tabular}

Hanania 2014

\begin{tabular}{|l|l}
\hline Reason for exclusion $\quad$ Study does not include mepolizumab \\
\hline
\end{tabular}

Hill 1982

\begin{tabular}{|l|l|}
\hline Reason for exclusion $\quad$ Study does not include mepolizumab \\
\hline
\end{tabular}

Hodsman 2013

Reason for exclusion

Study does not include mepolizumab

Holgate 2004

Reason for exclusion

Study does not include mepolizumab

Hoshino 2012

\begin{tabular}{|l|l|}
\hline Reason for exclusion & Study does not include mepolizumab
\end{tabular}

Humbert 2005

\begin{tabular}{|l|l}
\hline Reason for exclusion & Study does not include mepolizumab
\end{tabular}

Humbert 2008

\begin{tabular}{|l|l|}
\hline Reason for exclusion & Study does not include mepolizumab
\end{tabular}

Humbert 2009

Reason for exclusion

Study does not include mepolizumab

Jacquemin 1995

Reason for exclusion

Study does not include mepolizumab

Jutel 2005

Reason for exclusion

Study does not include mepolizumab 
MEP-AST Mepolizumab versus placebo for asthma

Kang 1988

Reason for exclusion

Study does not include mepolizumab

Kips 2003

Reason for exclusion

Study does not include mepolizumab

Kon 2001

Reason for exclusion

Study does not include mepolizumab

Kopp 2009

Reason for exclusion

Study does not include mepolizumab

Kopp 2013

Reason for exclusion

Study does not include mepolizumab

Kulus 2010

Reason for exclusion

Study does not include mepolizumab

Lanier 2003

Reason for exclusion

Study does not include mepolizumab

Lanier 2009

Reason for exclusion

Study does not include mepolizumab

Laviolette 2013

\begin{tabular}{|l|l}
\hline Reason for exclusion & Study does not include mepolizumab
\end{tabular}

Leynadier 2004

Reason for exclusion

Study does not include mepolizumab

Lizaso 2008

Reason for exclusion

Study does not include mepolizumab

Massanari 2009

Reason for exclusion

Study does not include mepolizumab

Massanari 2010

Reason for exclusion

Study does not include mepolizumab

Mathur 2011

Reason for exclusion

Study does not include Mepolizumab

Metzger 1998 
MEP-AST Mepolizumab versus placebo for asthma

\begin{tabular}{|l|l|}
\hline Reason for exclusion & Study does not include mepolizumab \\
\hline
\end{tabular}

Milgrom 1999

\begin{tabular}{|l|l|}
\hline Reason for exclusion & Study does not include mepolizumab \\
\hline
\end{tabular}

Milgrom 2001

\begin{tabular}{|l|l|}
\hline Reason for exclusion $\quad$ Study does not include mepolizumab & \\
\hline
\end{tabular}

\section{Modlin 1977}

\begin{tabular}{|l|l|}
\hline Reason for exclusion $\quad$ Study does not include mepolizumab \\
\hline
\end{tabular}

\section{Moss 1987}

\begin{tabular}{|l|l|}
\hline Reason for exclusion & Study does not include mepolizumab \\
\hline
\end{tabular}

Nair 2010

\begin{tabular}{|l|l|}
\hline Reason for exclusion & Study does not include mepolizumab \\
\hline
\end{tabular}

\section{NCT00802438}

\begin{tabular}{|l|l|}
\hline Reason for exclusion $\quad$ Non randomised study \\
\hline
\end{tabular}

\section{NCT01366521}

\begin{tabular}{|l|l|}
\hline Reason for exclusion & $\begin{array}{l}\text { Phase } 2 \text { study comparing three doses of Mepolizumab. This trial does not have a } \\
\text { placebo arm. }\end{array}$ \\
\hline
\end{tabular}

\section{NCT01471327}

Reason for exclusion

\section{NCT01691859}

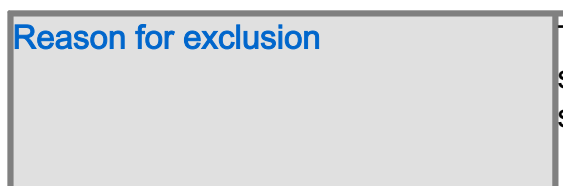

\section{NCT01842607}

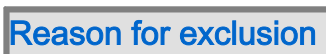

Focus of study was on tolerability, pharmacokinetics and pharmacodynamics of single dose SB-240563 administered intravenously to Japanese healthy male subjects. Patients with asthma were not included in the study
This study does not include a placebo group. Multi-centre, open-label, long term safety study with total sample receiving 100 milligrams $(\mathrm{mg})$ mepolizumab administered subcutaneously (no control group).

\section{NCT02135692}

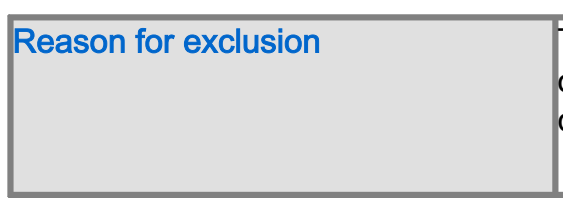

This study does not include a placebo group. Multi-centre, open-label, long term safety study with total sample receiving 100 milligrams $(\mathrm{mg})$ mepolizumab administered subcutaneously (no control group).

\section{NCT02293265}

This study does not include a placebo group. Multi-center, open-label, long-term study of subcutaneously (SC) administered mepolizumab 100mg in addition to standard of care (SOC), in subjects with severe eosinophilic asthma 
MEP-AST Mepolizumab versus placebo for asthma

Reason for exclusion

Study does not include mepolizumab (aim of study is to provide a 'reliable description of the severe asthma patient landscape with respect to the potential eligibility for treatment with mepolizumab, omalizumab, and reslizumab'),

Niven 2008

\begin{tabular}{|l|l}
\hline Reason for exclusion & Study does not include mepolizumab
\end{tabular}

\section{Noga 2003}

\begin{tabular}{|l|l|}
\hline Reason for exclusion & Study does not include mepolizumab \\
\hline
\end{tabular}

Noga 2008

\begin{tabular}{|l|l}
\hline Reason for exclusion & Study does not include mepolizumab
\end{tabular}

Noonan 2013

\begin{tabular}{|l|l|}
\hline Reason for exclusion & Study does not include mepolizumab
\end{tabular}

Oba 2004

\begin{tabular}{|l|l}
\hline Reason for exclusion & Study does not include mepolizumab
\end{tabular}

Oh 2013

\begin{tabular}{|l|l}
\hline Reason for exclusion & Study does not include mepolizumab
\end{tabular}

Ohashi 1997

\begin{tabular}{|l|l|}
\hline Reason for exclusion & Study does not include mepolizumab \\
\hline
\end{tabular}

Ohman 1984

\begin{tabular}{|l|l|}
\hline Reason for exclusion & Study does not include mepolizumab \\
\hline
\end{tabular}

Ohta 2009

\begin{tabular}{|l|l|}
\hline Reason for exclusion $\quad$ Study does not include mepolizumab \\
\hline
\end{tabular}

Ong 2005

\begin{tabular}{|l|l|}
\hline Reason for exclusion & Study does not include mepolizumab
\end{tabular}

Parker 2010

\begin{tabular}{|l|l|}
\hline Reason for exclusion & Study does not include mepolizumab \\
\hline
\end{tabular}

Pauli 1984

\begin{tabular}{|l|l}
\hline Reason for exclusion & Study does not include mepolizumab
\end{tabular}

Piper 2013

Reason for exclusion

Study does not include mepolizumab

Prieto 2006 
MEP-AST Mepolizumab versus placebo for asthma

\begin{tabular}{|l|l|}
\hline Reason for exclusion & Study does not include mepolizumab \\
\hline
\end{tabular}

\section{Pui 2010}

\begin{tabular}{|l|l}
\hline Reason for exclusion $\quad$ Study does not include mepolizumab \\
\hline
\end{tabular}

\section{Rose 2009}

\begin{tabular}{|l|l|}
\hline Reason for exclusion $\quad$ Study does not include mepolizumab \\
\hline
\end{tabular}

Sakamoto 1984

Reason for exclusion
Study does not include mepolizumab

Study does not include mepolizumab
Scheerens 2011

Reason for exclusion

\section{Scheerens 2014}

Reason for exclusion

\section{Siergiejko 2011}

Reason for exclusion

\section{Silk 1998}

Reason for exclusion

\section{Silkoff 2004}

Reason for exclusion

\section{Simoes 2007}

Reason for exclusion

Study does not include mepolizumab

\section{Singh 2010}

Reason for exclusion

Study does not include mepolizumab

Slavin 2009

Reason for exclusion

Study does not include mepolizumab

Soler 2001

Reason for exclusion

Study does not include mepolizumab

Sorkness 2013

Reason for exclusion

Does not include Mepolizumab

Sthoeger 2007

Reason for exclusion

Study does not include mepolizumab

Study does not include mepolizumab

Study does not include mepolizumab

Study does not include mepolizumab

Study does not include mepolizumab

Dos not include Mepolizumab

Study does not include mepolizumab 
MEP-AST Mepolizumab versus placebo for asthma

Sugaya 1994

\begin{tabular}{|l|l|}
\hline Reason for exclusion $\quad$ Study does not include mepolizumab \\
\hline
\end{tabular}

Swanson 2014

Reason for exclusion

Study does not include mepolizumab

Szymaniak 1998

\begin{tabular}{|l|l}
\hline Reason for exclusion $\quad$ Study does not include mepolizumab \\
\hline
\end{tabular}

Tanaka 1993

\begin{tabular}{|l|l}
\hline Reason for exclusion & Study does not include mepolizumab
\end{tabular}

Terr 1969

\begin{tabular}{|l|l}
\hline Reason for exclusion & Study does not include mepolizumab
\end{tabular}

Van Rensen 2009

\begin{tabular}{|l|l|}
\hline Reason for exclusion $\quad$ Study does not include mepolizumab \\
\hline
\end{tabular}

Vignola 2004

\begin{tabular}{|l|l|}
\hline Reason for exclusion & Study does not include mepolizumab
\end{tabular}

Wark 2003

\begin{tabular}{|l|l}
\hline Reason for exclusion & Study does not include mepolizumab
\end{tabular}

Wenzel 2009

\begin{tabular}{|l|l}
\hline Reason for exclusion & Study does not include mepolizumab
\end{tabular}

Wenzel 2013

\begin{tabular}{|l|l|}
\hline Reason for exclusion & Study does not include mepolizumab
\end{tabular}

Zetterstrom 1972

Reason for exclusion

Study does not include mepolizumab

Zhu 2013

\begin{tabular}{|l|l|}
\hline Reason for exclusion & Study does not include mepolizumab
\end{tabular}

Zielen 2013

\begin{tabular}{|l|l}
\hline Reason for exclusion & Study does not include mepolizumab
\end{tabular}

Footnotes

Characteristics of studies awaiting classification

Footnotes

Characteristics of ongoing studies

NCT01520051 2012 
MEP-AST Mepolizumab versus placebo for asthma

\begin{tabular}{|c|c|}
\hline Study name & Mepolizumab treatment for rhinovirus-induced asthma exacerbations (MATERIAL) \\
\hline Methods & Randomised double blind trial \\
\hline Participants & 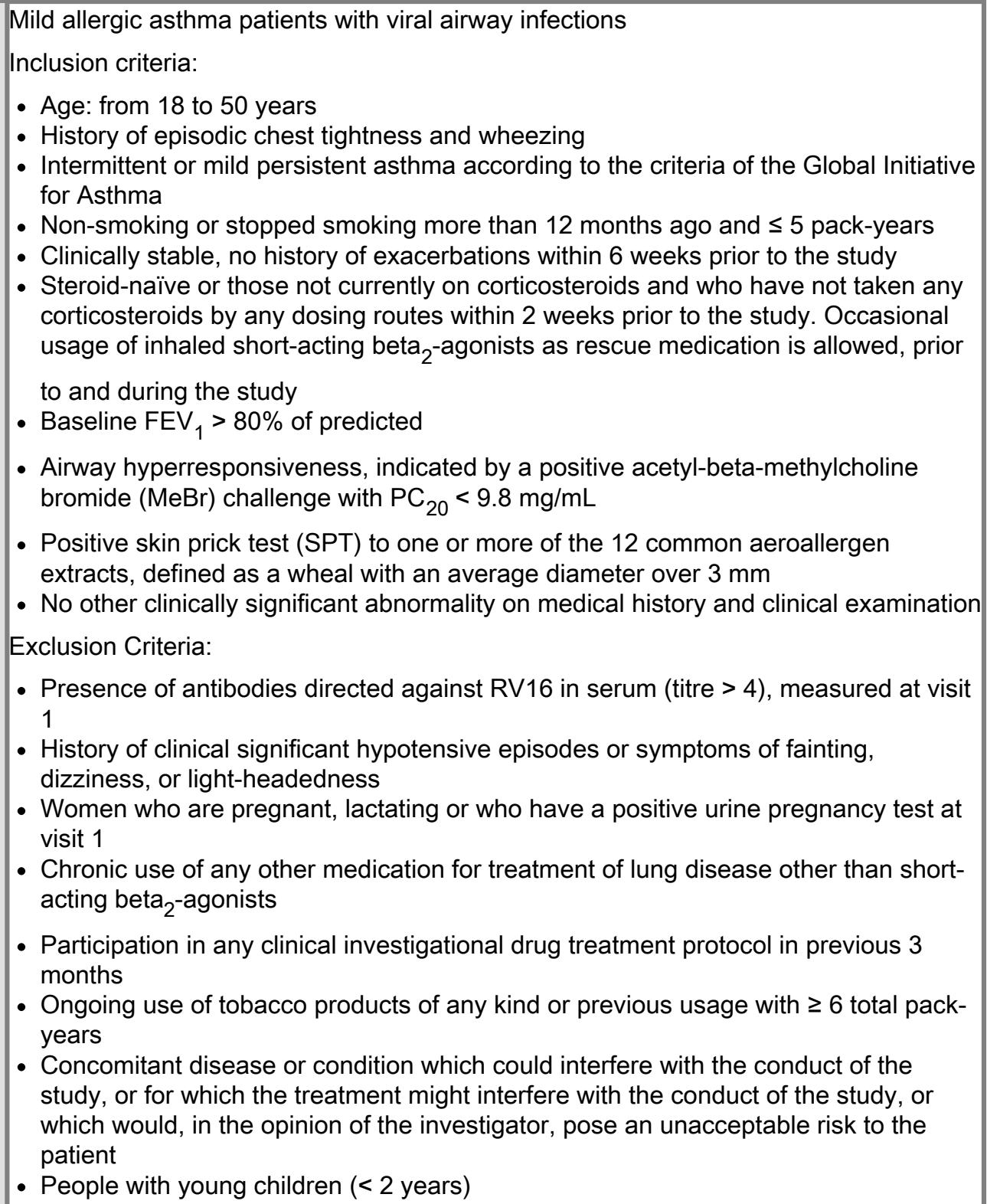 \\
\hline Interventions & $\begin{array}{l}3 \text { monthly intravenous infusions of } 750 \mathrm{mg} \text { versus } 3 \text { monthly intravenous infusions with } \\
\text { saline }\end{array}$ \\
\hline Outcomes & $\begin{array}{l}\text { Primary outcome measures: } \\
\text { - FEV } 1 \text { day prior and } 6 \text { days after RV16 challenge } \\
\text { - Questionnaire to score asthma and common cold complaints during } 14 \text { days } \\
\text { following viral infection } \\
\text { Secondary outcome measures: } \\
\text { - Viral load on day } 6 \text { after viral infection } \\
\text { - Sputum eosinophils before and after mepolizumab infusion } \\
\text { - Cell influx in bronchoalveolar lavage fluid } 6 \text { days after viral infection } \\
\text { - Pro-inflammatory cytokines in bronchoalveolar lavage fluid } 6 \text { days after viral } \\
\text { infection }\end{array}$ \\
\hline
\end{tabular}


MEP-AST Mepolizumab versus placebo for asthma

\begin{tabular}{|l|l|}
\hline Starting date & January 2012 \\
\hline Contact information & Suzanne Bal, Academisch Medisch Centrum - Universiteit van Amsterdam (AMC-UvA) \\
\hline Notes & \\
\hline
\end{tabular}

NCT02281318 2014

\begin{tabular}{|c|c|}
\hline Study name & $\begin{array}{l}\text { A randomised, double-blind, placebo-controlled, parallel-group, multi-centre, 24-week } \\
\text { study to evaluate the efficacy and safety of mepolizumab adjunctive therapy in subjects } \\
\text { with severe eosinophilic asthma on markers of asthma control }\end{array}$ \\
\hline Methods & Multicentre, placebo-controlled, double-blind, parallel-group study \\
\hline Participants & $\begin{array}{l}\text { People with severe eosinophilic asthma. Approximately } 780 \text { participants with severe } \\
\text { eosinophilic asthma will be screened to ensure the randomisation of } 544 \text { participants } \\
\text { (272 participants per treatment group) into the study. }\end{array}$ \\
\hline Interventions & $\begin{array}{l}\text { Mepolizumab } 100 \mathrm{mg} \text { subcutaneously into the upper arm or thigh every } 4 \text { weeks for a } \\
\text { period of } 24 \text { weeks (total of } 6 \text { doses) along with their respective standard care of } \\
\text { treatment, } \\
\text { versus } \\
\text { placebo ( } 0.9 \% \text { sodium chloride) subcutaneously into the upper arm or thigh every } 4 \\
\text { weeks for a period of } 24 \text { weeks (total of } 6 \text { doses) along with their respective standard } \\
\text { care of treatment }\end{array}$ \\
\hline Outcomes & $\begin{array}{l}\text { Primary Outcome Measure: } \\
\text { - Mean change from baseline in St. George's Respiratory Questionnaire (SGRQ) } \\
\text { score at week } 24 \\
\text { Secondary Outcome Measures: } \\
\text { - Mean change from baseline in clinic pre-bronchodilator } \mathrm{FEV}_{1} \text { at week } 24 \\
\text { - Percentage of participants achieving a } 4 \text { point or greater reduction from baseline in } \\
\text { SGRQ score at week } 24 \\
\text { - Mean change from baseline in five-item Asthma Control Questionnaire (ACQ-5) } \\
\text { score at week } 24\end{array}$ \\
\hline Starting date & December 2014 \\
\hline Contact information & US GSK Clinical Trials Call Center: GSKClinicalSupportHD@gsk.com \\
\hline Notes & Estimated primary completion date: 2016 \\
\hline
\end{tabular}

Footnotes

$\mathrm{FEV}_{1}$ : Forced expiratory volume in 1 second; $\mathrm{PC}_{20}$ : histamine provocative concentration causing a $20 \%$ drop in $\mathrm{FEV}$

\section{Summary of findings tables}

1 Intravenous mepolizumab compared to placebo for asthma

IV mepolizumab compared to placebo for asthma

Patient or population: adults with asthma of varying degrees of severity

Settings: community

Intervention: intravenous (IV) mepolizumab

Comparison: placebo 
MEP-AST Mepolizumab versus placebo for asthma

\begin{tabular}{|c|c|c|c|c|c|c|}
\hline \multirow[t]{3}{*}{ Outcomes } & \multicolumn{2}{|c|}{ Illustrative comparative risks* $(95 \% \mathrm{Cl})$} & \multirow{3}{*}{$\begin{array}{l}\text { Relative } \\
\text { effect } \\
(95 \% \mathrm{Cl})\end{array}$} & \multirow{3}{*}{$\begin{array}{l}\text { No. of } \\
\text { participants } \\
\text { (studies) }\end{array}$} & \multirow{3}{*}{$\begin{array}{l}\text { Quality of } \\
\text { the } \\
\text { evidence } \\
\text { (GRADE) }\end{array}$} & \multirow[t]{3}{*}{ Comments } \\
\hline & \multirow{2}{*}{$\begin{array}{l}\text { Assumed risk } \\
\text { Placebo }\end{array}$} & \multirow{2}{*}{$\begin{array}{l}\text { Corresponding risk } \\
\text { IV mepolizumab }\end{array}$} & & & & \\
\hline & & & & & & \\
\hline $\begin{array}{l}\text { Change in HRQoL } \\
\text { assessed with } \\
\text { AQLQ. } \\
\text { Scale from } 1 \text { to } 7 \\
\text { (higher is better) } \\
\text { Follow-up: } 52 \text { weeks }\end{array}$ & $\begin{array}{l}\text { The mean change in } \\
\text { HRQoL ranged from } \\
0.18 \text { to } 0.71 \text { units }\end{array}$ & $\begin{array}{l}\text { The mean change in } \\
\text { HRQoL in the intervention } \\
\text { group was } 0.21 \text { units more } \\
\text { ( } 0.01 \text { fewer to } 0.44 \text { more) }\end{array}$ & - & $\begin{array}{l}682 \\
\text { (2 RCTs) }\end{array}$ & $\begin{array}{l}\oplus \oplus \ominus \ominus \\
\text { low }^{a, b}\end{array}$ & $\begin{array}{l}\text { Trial } \\
\text { participants } \\
\text { had severe } \\
\text { eosinophilic } \\
\text { asthma }\end{array}$ \\
\hline $\begin{array}{l}\text { Change in HRQoL } \\
\text { assessed with } \\
\text { SGRQ. } \\
\text { Scale from: } 0 \text { to } 100 \\
\text { (lower is better) } \\
\text { Follow-up: } 32 \text { weeks }\end{array}$ & $\begin{array}{l}\text { The mean change in } \\
\text { HRQoL was - } 9.0 \\
\text { units }\end{array}$ & $\begin{array}{l}\text { The mean change in } \\
\text { HRQoL in the intervention } \\
\text { group was } 6.4 \text { units lower } \\
\text { ( } 3.15 \text { lower to } 9.65 \text { lower) }\end{array}$ & - & $\begin{array}{l}382 \\
(1 \mathrm{RCT})\end{array}$ & $\begin{array}{l}\oplus \oplus \oplus \ominus \\
\text { moderate }\end{array}$ & $\begin{array}{l}\text { Trial } \\
\text { participants } \\
\text { had severe } \\
\text { eosinophilic } \\
\text { asthma }\end{array}$ \\
\hline $\begin{array}{l}\text { Rate of clinically } \\
\text { significant } \\
\text { exacerbations - } 75 \\
\text { mg mepolizumab } \\
\text { versus placebo } \\
\text { Follow-up: range } 32 \\
\text { to } 52 \text { weeks }\end{array}$ & $\begin{array}{l}\text { The mean rate of } \\
\text { clinically significant } \\
\text { exacerbations on } \\
\text { placebo was } 1 \text { per } \\
\text { patient per yearc }\end{array}$ & $\begin{array}{l}\text { The mean rate of clinically } \\
\text { significant exacerbations in } \\
\text { the intervention group was } \\
0.48 \text { less per patient per } \\
\text { year ( } 0.57 \text { less to } 0.46 \text { less) }\end{array}$ & $\begin{array}{l}\text { Rate ratio } \\
0.52(0.43 \\
\text { to } 0.64)\end{array}$ & $\begin{array}{l}690 \\
(2 \text { studies })\end{array}$ & $\begin{array}{l}\oplus \oplus \oplus \ominus \\
\text { moderate }\end{array}$ & $\begin{array}{l}\text { Trial } \\
\text { participants } \\
\text { had severe } \\
\text { eosinophilic } \\
\text { asthma }\end{array}$ \\
\hline $\begin{array}{l}\text { Rate of clinically } \\
\text { significant } \\
\text { exacerbations - } 250 \\
\text { mg mepolizumab } \\
\text { versus placebo } \\
\text { Follow-up: } 52 \text { weeks }\end{array}$ & $\begin{array}{l}\text { The mean rate of } \\
\text { clinically significant } \\
\text { exacerbations on } \\
\text { placebo was } 0.43 \text { per } \\
\text { patient per year }\end{array}$ & $\begin{array}{l}\text { The mean rate of clinically } \\
\text { significant exacerbations in } \\
\text { the intervention group was } \\
0.17 \text { less per patient per } \\
\text { year ( } 0.08 \text { less to } 0.23 \text { less) }\end{array}$ & $\begin{array}{l}\text { Rate ratio } \\
0.61(0.46 \\
\text { to } 0.81)\end{array}$ & $\begin{array}{l}307 \\
(1 \text { study })\end{array}$ & $\begin{array}{l}\oplus \oplus \oplus \ominus \\
\text { moderate }\end{array}$ & $\begin{array}{l}\text { Trial } \\
\text { participants } \\
\text { had severe } \\
\text { eosinophilic } \\
\text { asthma }\end{array}$ \\
\hline $\begin{array}{l}\text { Rate of clinically } \\
\text { significant } \\
\text { exacerbations - } 750 \\
\text { mg mepolizumab } \\
\text { versus placebo } \\
\text { Follow-up: } 52 \text { weeks }\end{array}$ & $\begin{array}{l}\text { The mean rate of } \\
\text { clinically significant } \\
\text { exacerbations on } \\
\text { placebo was } 0.43 \text { per } \\
\text { patient per year }\end{array}$ & $\begin{array}{l}\text { The mean rate of clinically } \\
\text { significant exacerbations in } \\
\text { the intervention group was } \\
0.22 \text { less per patient per } \\
\text { year ( } 0.17 \text { less to } 0.25 \text { less) }\end{array}$ & $\begin{array}{l}\text { Rate ratio } \\
0.48(0.36 \\
\text { to } 0.64)\end{array}$ & $\begin{array}{l}311 \\
(1 \text { study })\end{array}$ & $\begin{array}{l}\oplus \oplus \oplus \ominus \\
\text { moderate }\end{array}$ & $\begin{array}{l}\text { Trial } \\
\text { participants } \\
\text { had severe } \\
\text { eosinophilic } \\
\text { asthma }\end{array}$ \\
\hline $\begin{array}{l}\text { People with one or } \\
\text { more exacerbations } \\
\text { Follow-up: } 20 \text { to } 50 \\
\text { weeks }\end{array}$ & 264 per 1000 & $\begin{array}{l}177 \text { per } 1000 \\
(90 \text { to } 345)\end{array}$ & $\begin{array}{l}\text { Risk ratio } \\
0.67 \\
(0.34 \text { to } \\
1.31)\end{array}$ & $\begin{array}{l}467 \\
\text { (4 studies) }\end{array}$ & $\begin{array}{l}\oplus \oplus \ominus \ominus \\
\text { low }^{a}, \mathrm{~d}\end{array}$ & $\begin{array}{l}\text { Variety of } \\
\text { asthma severity } \\
\text { in the trials }\end{array}$ \\
\hline $\begin{array}{l}\text { Serious adverse } \\
\text { events } \\
\text { Follow-up: } 20 \text { to } 52 \\
\text { weeks }\end{array}$ & 82 per 1000 & $\begin{array}{l}40 \text { per } 1000 \\
(24 \text { to } 65)\end{array}$ & $\begin{array}{l}\text { Risk ratio } \\
0.49 \\
(0.30 \text { to } \\
0.80)\end{array}$ & $\begin{array}{l}1441 \\
\text { (5 studies) }\end{array}$ & $\begin{array}{l}\oplus \oplus \oplus \ominus \\
\text { moderate }^{a}\end{array}$ & $\begin{array}{l}\text { Variety of } \\
\text { asthma severity } \\
\text { in the trials }\end{array}$ \\
\hline \multicolumn{7}{|c|}{$\begin{array}{l}\text { *The basis for the assumed risk is the mean control group risk across studies. The corresponding risk (and its } 95 \% \\
\text { confidence interval) is based on the assumed risk in the comparison group and the relative effect of the intervention (and its } \\
95 \% \mathrm{CI}) \text {. } \\
\text { AQLQ: Asthma Quality of Life Questionnaire; Cl: Confidence interval; HRQoL: health-related quality of life; IV: intravenous; } \\
\text { RCT: randomised controlled trial; SGRQ: St George's Respiratory Questionnaire. }\end{array}$} \\
\hline \multicolumn{7}{|c|}{$\begin{array}{l}\text { GRADE Working Group grades of evidence } \\
\text { High quality: Further research is very unlikely to change our confidence in the estimate of effect. } \\
\text { Moderate quality: Further research is likely to have an important impact on our confidence in the estimate of effect and may } \\
\text { change the estimate. } \\
\text { Low quality: Further research is very likely to have an important impact on our confidence in the estimate of effect and is } \\
\text { likely to change the estimate. } \\
\text { Very low quality: We are very uncertain about the estimate. }\end{array}$} \\
\hline
\end{tabular}


The intravenous route is not currently licenced for mepolizumab; one point deducted for indirectness.

${ }^{b}$ The mean difference is less than the clinical minimally important difference ( 0.5 units), and no responder analysis is available; one point deducted.

${ }^{\mathrm{C}}$ Placebo exacerbation rate per patient per year is the rounded mean of rate in the placebo arm of the two studies $(0.43$ and 1.75).

dWide confidence interval increases the uncertainty of this outcome; one point deducted.

2 Subcutaneous mepolizumab compared to placebo for asthma 


\begin{tabular}{|c|c|c|c|c|c|c|}
\hline \multicolumn{7}{|c|}{ Subcutaneous mepolizumab compared to placebo for asthma } \\
\hline \multicolumn{7}{|c|}{$\begin{array}{l}\text { Patient or population: adults with severe eosinophilic asthma } \\
\text { Settings: community } \\
\text { Intervention: subcutaneous (SC) mepolizumab } \\
\text { Comparison: placebo }\end{array}$} \\
\hline \multirow[t]{3}{*}{ Outcomes } & \multicolumn{2}{|c|}{ Illustrative comparative risks* $(95 \% \mathrm{Cl})$} & \multirow{3}{*}{$\begin{array}{l}\text { Relative } \\
\text { effect } \\
(95 \% \mathrm{Cl})\end{array}$} & \multirow{3}{*}{$\begin{array}{l}\text { No. of } \\
\text { participants } \\
\text { (studies) }\end{array}$} & \multirow{3}{*}{$\begin{array}{l}\text { Quality of } \\
\text { the } \\
\text { evidence } \\
\text { (GRADE) }\end{array}$} & \multirow[t]{3}{*}{ Comments } \\
\hline & Assumed risk & Corresponding risk & & & & \\
\hline & Placebo & SC mepolizumab & & & & \\
\hline $\begin{array}{l}\text { Change in HRQoL } \\
\text { assessed with } \\
\text { SGRQ. } \\
\text { Scale from: } 0 \text { to } 100 \\
\text { (lower is better) } \\
\text { Follow-up: } 32 \\
\text { weeks }\end{array}$ & $\begin{array}{l}\text { The mean HRQoL was - } \\
9.0 \text { units }\end{array}$ & $\begin{array}{l}\text { The mean HRQoL - SGRQ in } \\
\text { the intervention group was } 7 \\
\text { units fewer (10.19 fewer to } 3.81 \\
\text { fewer) }\end{array}$ & & $\begin{array}{l}385 \\
(1 \mathrm{RCT})\end{array}$ & $\begin{array}{l}\oplus \oplus \oplus \ominus \\
\text { moderate }^{a}\end{array}$ & \\
\hline $\begin{array}{l}\text { Rate of } \\
\text { exacerbations } \\
\text { requiring admission } \\
\text { Follow-up: } 32 \\
\text { weeks }\end{array}$ & $\begin{array}{l}\text { The mean rate of } \\
\text { exacerbations requiring } \\
\text { admission on placebo } \\
\text { was } 0.10 \text { per patient per } \\
\text { year }\end{array}$ & $\begin{array}{l}\text { The mean rate of exacerbations } \\
\text { requiring ED visit or admission } \\
\text { in the intervention group was } \\
0.07 \text { less per patient per year } \\
\text { ( } 0.01 \text { less to } 0.09 \text { less) }\end{array}$ & $\begin{array}{l}\text { Rate } \\
\text { ratio } \\
0.31 \\
(0.11 \text { to } \\
0.91)\end{array}$ & $\begin{array}{l}385 \\
(1 \mathrm{RCT})\end{array}$ & $\begin{array}{l}\oplus \oplus \oplus \ominus \\
\text { moderate }^{a}\end{array}$ & \\
\hline $\begin{array}{l}\text { Rate of } \\
\text { exacerbations } \\
\text { requiring ED or } \\
\text { admission } \\
\text { Follow-up: } 32 \\
\text { weeks }\end{array}$ & $\begin{array}{l}\text { The mean rate of } \\
\text { exacerbations requiring } \\
\text { ED or admission on } \\
\text { placebo was } 0.20 \text { per } \\
\text { patient per year }\end{array}$ & $\begin{array}{l}\text { The mean rate of exacerbations } \\
\text { requiring ED or admission in the } \\
\text { intervention group was } 0.12 \\
\text { less per patient per year ( } 0.03 \\
\text { less to } 0.16 \text { less) }\end{array}$ & $\begin{array}{l}\text { Rate } \\
\text { ratio } \\
0.39 \\
(0.18 \text { to } \\
0.83)\end{array}$ & $\begin{array}{l}385 \\
(1 \mathrm{RCT})\end{array}$ & $\begin{array}{l}\oplus \oplus \oplus \ominus \\
\text { moderate }^{a}\end{array}$ & \\
\hline $\begin{array}{l}\text { Rate of clinically } \\
\text { significant } \\
\text { exacerbations } \\
\text { Follow-up: } 32 \\
\text { weeks }\end{array}$ & $\begin{array}{l}\text { The mean rate of } \\
\text { clinically significant } \\
\text { exacerbations on } \\
\text { placebo was } 1.75 \text { per } \\
\text { patient per year }\end{array}$ & $\begin{array}{l}\text { The mean rate of clinically } \\
\text { significant exacerbations in the } \\
\text { intervention group was } 0.93 \\
\text { less per patient per year ( } 0.65 \\
\text { less to } 1.14 \text { less) }\end{array}$ & $\begin{array}{l}\text { Rate } \\
\text { ratio } \\
0.47 \\
(0.35 \text { to } \\
0.63)\end{array}$ & $\begin{array}{l}385 \\
(1 \mathrm{RCT})\end{array}$ & $\begin{array}{l}\oplus \oplus \oplus \ominus \\
\text { moderate }^{a}\end{array}$ & \\
\hline $\begin{array}{l}\text { Asthma symptoms } \\
\text { measured on } \\
\text { Asthma Control } \\
\text { Questionnaire } \\
\text { Scale from: } 0 \text { to } 6 \\
\text { (lower is better) }^{b} \\
\text { Follow-up: } 32 \\
\text { weeks }\end{array}$ & $\begin{array}{l}\text { The mean change in } \\
\text { asthma symptoms was - } \\
0.5 \text { units }\end{array}$ & $\begin{array}{l}\text { The mean asthma symptoms in } \\
\text { the intervention group was } 0.44 \\
\text { units fewer ( } 0.64 \text { fewer to } 0.24 \\
\text { fewer) }\end{array}$ & & $\begin{array}{l}385 \\
(1 \mathrm{RCT})\end{array}$ & $\begin{array}{l}\oplus \oplus \oplus \ominus \\
\text { low }^{a, c}\end{array}$ & \\
\hline \multicolumn{7}{|c|}{$\begin{array}{l}\text { *The basis for the assumed risk was the event rate in the placebo arm of the single included study. The corresponding risk } \\
\text { (and its } 95 \% \text { confidence interval) is based on the assumed risk in the comparison group and the relative effect of the } \\
\text { intervention (and its } 95 \% \mathrm{Cl} \text { ). } \\
\mathrm{Cl} \text { : Confidence interval; ED: emergency department; HRQoL: health-related quality of life; RCT: randomised controlled trial; } \\
\text { SC: subcutaneous; SGRQ: St George's Respiratory Questionnaire. }\end{array}$} \\
\hline \multicolumn{7}{|c|}{$\begin{array}{l}\text { GRADE Working Group grades of evidence } \\
\text { High quality: Further research is very unlikely to change our confidence in the estimate of effect. } \\
\text { Moderate quality: Further research is likely to have an important impact on our confidence in the estimate of effect and may } \\
\text { change the estimate. } \\
\text { Low quality: Further research is very likely to have an important impact on our confidence in the estimate of effect and is } \\
\text { likely to change the estimate. } \\
\text { Very low quality: We are very uncertain about the estimate. }\end{array}$} \\
\hline
\end{tabular}

\section{Footnotes}

aThis finding is from a single study so we do not know how well this will match further research; one point deducted.

${ }^{b}$ The minimal clinically important difference on this scale is 0.5 units.

${ }^{\mathrm{c}}$ The mean difference is less than the clinical minimally important difference ( 0.5 units), and no responder analysis is 
available; one point deducted.

\section{Additional tables}

\section{Comparisons of study characteristics}

\begin{tabular}{|c|c|c|c|c|c|c|c|c|}
\hline Study & Design & $\begin{array}{l}\text { Baseline } \\
\text { Asthma } \\
\text { severity }\end{array}$ & $\begin{array}{l}\text { Baseline } \\
\text { treatment }\end{array}$ & $\begin{array}{l}\text { SC } \\
\text { or } \\
\text { IV }\end{array}$ & $\begin{array}{l}\text { Intervention } \\
\text { (mepolizumab) }\end{array}$ & $\begin{array}{l}\text { Follow- } \\
\text { up }\end{array}$ & $\begin{array}{l}\text { Primary and secondary } \\
\text { outcomes }\end{array}$ & $\begin{array}{l}\text { No. } \\
\text { participants }\end{array}$ \\
\hline$\frac{\text { Leckie }}{2000}$ & $\begin{array}{l}\text { RCT double- } \\
\text { blind, placebo }\end{array}$ & $\begin{array}{l}\text { Mild allergic } \\
\text { asthma }\end{array}$ & $\begin{array}{l}\text { SABA as } \\
\text { required }\end{array}$ & IV & $\begin{array}{l}10 \mathrm{mg} / \mathrm{kg} \text { versus } \\
2.5 \mathrm{mg} / \mathrm{kg} \\
\text { versus placebo }\end{array}$ & weeks & $\begin{array}{l}\text { Blood eosinophils, sputum } \\
\text { eosinophils, histamine } \mathrm{PC}_{20} \\
(\mathrm{mg} / \mathrm{mL} \text { ), late asthmatic } \\
\text { reaction (maximum \% fall in } \\
\mathrm{FEV}_{1} \text { ) }\end{array}$ & 24 \\
\hline$\frac{\text { Buttner }}{2003}$ & $\begin{array}{l}\text { RCT parallel } \\
\text { group, } \\
\text { multicentre } \\
\text { double blind }\end{array}$ & $\begin{array}{l}\text { Mild or } \\
\text { moderate } \\
\text { asthma (FEV } 1 \\
50-80 \% \\
\text { predicted) }\end{array}$ & $\begin{array}{l}1000 \text { mcg BDP } \\
\text { or equivalent } \\
\text { and stable }\end{array}$ & IV & $\begin{array}{l}\text { Three } 750 \text { or } \\
250 \text { mg or } \\
\text { placebo every } 4 \\
\text { weeks for } 6 \\
\text { months }\end{array}$ & 6 & $\begin{array}{l}\text { Blood eosinophil, ECP, } \\
\text { interferon-c producing CD4 } \\
\text { T-cells }\end{array}$ & 19 \\
\hline$\frac{\text { Flood- }}{\text { Page }}$ & $\begin{array}{l}\text { 2-centre } \\
\text { double-blind, } \\
\text { placebo- } \\
\text { controlled, } \\
\text { parallel-group } \\
\text { study }\end{array}$ & $\begin{array}{l}\text { Mild atopic } \\
\text { (skin prick } \\
\text { positive) }\urcorner \\
\text { asthma (FEV } 1 \\
>70 \% \\
\text { predicted) }\end{array}$ & $\begin{array}{l}\text { SABA as } \\
\text { required and no } \\
\text { corticosteroids } \\
\text { in previous } 8 \\
\text { weeks }\end{array}$ & IV & $\begin{array}{l}\text { Three doses of } \\
\text { either } 750 \text { mg } 7 \\
\text { or placebo over } \\
20 \text { weeks (at } \\
\text { weeks } 0,4 \text { and } \\
\text { 8) }\end{array}$ & $\begin{array}{l}20 \\
\text { weeks }\end{array}$ & $\begin{array}{l}\text { Airway eosinophils, bone } \\
\text { marrow eosinophils, blood } \\
\text { eosinophils, airway } \\
\text { hyperresponsiveness, } \mathrm{FEV}_{1} \text {, } \\
\text { PEFR }\end{array}$ & 24 \\
\hline$\frac{\text { Flood- }}{\frac{\text { Page }}{2007}}$ & $\begin{array}{l}\text { Multicentre, } \\
\text { randomised, } \\
\text { double-blind, } \\
\text { placebo- } \\
\text { controlled trial }\end{array}$ & $\begin{array}{l}\text { Moderate } \\
\text { asthma (FEV } 1 \\
\text { between } 50 \% \\
\text { and } 80 \% \\
\text { predicted) }\end{array}$ & $\begin{array}{l}\text { maximum dose } \\
\text { (BDP) or } \\
\text { equivalent, } 1000 \\
\mathrm{mcg} / \mathrm{d}\end{array}$ & IV & $\begin{array}{l}\text { Three doses of } \\
\text { either } 750 \mathrm{mg} \text { or } \\
250 \mathrm{mg} \text { or } \\
\text { placebo over } 20 \\
\text { weeks (at } \\
\text { weeks } 0,4 \text { and } \\
\text { 8) }\end{array}$ & 20 & $\begin{array}{l}\text { Change from baseline } \\
\text { morning PEFR recorded at } \\
\text { weeks } 12 \text { and } 20 \text {; asthma } \\
\text { summary symptom scores; } \\
\text { use of rescue medication } \\
\text { such as albuterol } \\
\text { (salbutamol); quality of life } \\
\text { scores; asthma exacerbation } \\
\text { rates; eosinophil counts in } \\
\text { blood and sputum }\end{array}$ & 362 \\
\hline$\frac{\text { Nair }}{2009}$ & $\begin{array}{l}\text { Randomised, } \\
\text { double-blind, } \\
\text { placebo- } \\
\text { controlled } \\
\text { trial. } \\
\neg\end{array}$ & $\begin{array}{l}\text { Eosinophilic } \\
\text { asthma }\end{array}$ & $\begin{array}{l}\text { Prednisolone } \\
\text { treatment with } \\
\text { high-dose ICS }\end{array}$ & IV & $\begin{array}{l}\text { Five doses of } \\
\text { either } 750 \mathrm{mg} \text { or } \\
\text { placebo } \\
\text { (administered in } \\
5 \text { monthly } \\
\text { infusions) } \\
\neg\end{array}$ & 26 weeks & 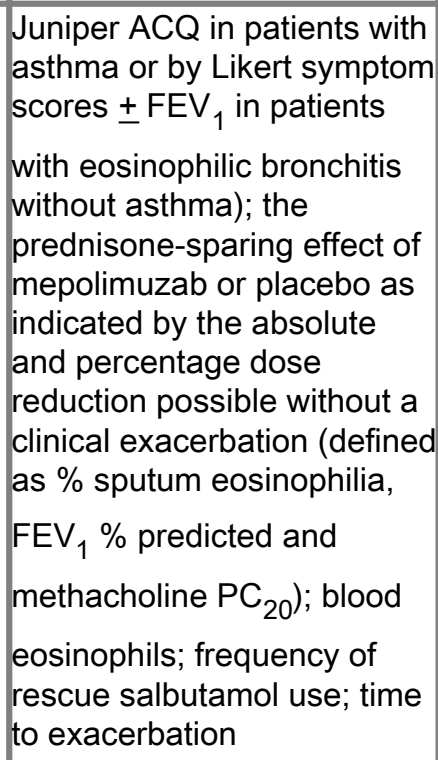 & 20 \\
\hline
\end{tabular}


MEP-AST Mepolizumab versus placebo for asthma

\begin{tabular}{|c|c|c|c|c|c|c|c|c|}
\hline Study & Design & $\begin{array}{l}\text { Baseline } \\
\text { Asthma } \\
\text { severity }\end{array}$ & $\begin{array}{l}\text { Baseline } \\
\text { treatment }\end{array}$ & $\begin{array}{l}\text { SC } \\
\text { or } \\
\text { IV }\end{array}$ & $\begin{array}{l}\text { Intervention } \\
\text { (mepolizumab) }\end{array}$ & $\begin{array}{l}\text { Follow- } \\
\text { up }\end{array}$ & $\begin{array}{l}\text { Primary and secondary } \\
\text { outcomes }\end{array}$ & $\begin{array}{l}\text { No. } \\
\text { participants }\end{array}$ \\
\hline$\frac{\text { Haldar }}{2009}$ & $\begin{array}{l}\text { RCT double- } \\
\text { blind, } \\
\text { placebo, } \\
\text { parallel-group }\end{array}$ & $\begin{array}{l}\text { Eosinophilic } \\
\text { asthma and } \\
\text { exacerbations }\end{array}$ & $\begin{array}{l}\text { Sputum } \\
\text { eosinophilia of } \\
\text { more than } 3 \% \\
\text { despite high- } \\
\text { dose ICS } \\
\text { treatment, and } \\
\text { at least two } \\
\text { exacerbations in } \\
\text { previous } 12 \\
\text { months }\end{array}$ & IV & $\begin{array}{l}750 \text { mg versus } \\
\text { matched } \\
\text { placebo (150 } \\
\text { mL of } 0.9 \% \\
\text { saline) at } \\
\text { monthly } \\
\text { intervals for } 1 \\
\text { year }\end{array}$ & weeks & $\begin{array}{l}\text { Severe exacerbations per } \\
\text { person; secondary outcomes } \\
\text { included a change in asthma } \\
\text { symptoms (AQLQ); FEV } 1 \\
\text { after use of a bronchodilator; } \\
\text { airway hyperresponsiveness; } \\
\text { eosinophil counts in the } \\
\text { blood, sputum }\end{array}$ & 61 \\
\hline$\frac{\text { Pavord }}{2012}$ & $\begin{array}{l}\text { Multicentre, } \\
\text { double-blind, } \\
\text { placebo- } \\
\text { controlled trial }\end{array}$ & $\begin{array}{l}\text { Eosinophilic } \\
\text { asthma and } \\
\text { exacerbations }\end{array}$ & $\begin{array}{l}\text { High dose ICS } \\
\text { (i.e. } \geq 880 \\
\text { mcg/day FP or } \\
\text { equivalent daily) } \\
\text { for at least } 12 \\
\text { months }\end{array}$ & IV & $\begin{array}{l}13 \text { infusions in } \\
\text { total given every } \\
4 \text { weeks of } 750 \\
\mathrm{mg}, 250 \mathrm{mg}, 75 \\
\mathrm{mg} \text { or placebo } 7\end{array}$ & $\begin{array}{l}52 \\
y \text { weeks }\end{array}$ & $\begin{array}{l}\text { Exacerbations; time to first } \\
\text { clinically significant } \\
\text { exacerbation; frequency of } \\
\text { exacerbations requiring } \\
\text { hospitalisation; time to first } \\
\text { exacerbation requiring } \\
\text { hospitalisation or ED visit; } \\
\text { mean change from baseline }_{\text {in clinic pre-bronchodilator }} \\
\text { FEV }_{1} \text {; mean change from } \\
\text { baseline in clinic post- }_{\text {bronchodilator FEV }} \text {; mean } \\
\text { change from baseline in } \\
\text { ACQ score }\end{array}$ & 621 \\
\hline$\frac{\text { Ortega }}{2014}$ & $\begin{array}{l}\text { Randomised, } \\
\text { double-blind, } \\
\text { double- } \\
\text { dummy, } \\
\text { phase } 3 \text { study }\end{array}$ & $\begin{array}{l}\text { Persistent } \\
\text { eosinophilic } \\
\text { asthma }\end{array}$ & $\begin{array}{l}\text { High dose ICS } \\
\text { in the } 12 \text { months } \\
\text { prior to visit } 1 \\
\text { with or without } \\
\text { maintenance } \\
\text { OCS }\end{array}$ & $\begin{array}{l}\text { IV } \\
\text { and } \\
\text { SC }\end{array}$ & $\begin{array}{l}75 \mathrm{mg} \text { IV dose } \\
\text { versus } 100 \mathrm{mg} \\
\text { SC dose versus } \\
\text { placebo every } 4 \\
\text { weeks for } 32 \\
\text { weeks }\end{array}$ & 32 & $\begin{array}{l}\text { Exacerbations per year; } \\
\text { mean change from baseline } \\
\text { in clinic pre-bronchodilator } \\
\text { FEV }_{1} \text { at week } 32 ; \text { mean } \\
\text { change from baseline in the } \\
\text { SGRQ total score at week } \\
32\end{array}$ & 576 \\
\hline
\end{tabular}

\section{Footnotes}

ACQ: Asthma Control Questionnaire; AQLQ: Asthma Quality of Life Questionnaire; BDP: beclomethasone dipropionate; ECP : eosinophil cationic protein; ED: emergency department; FEV 1 : Forced expiratory volume in 1 second; FP; fluticasone propionate; ICS; inhaled corticosteroid; IV: intravenous; $\mathbf{P C}_{20}$ : histamine provocative concentration causing a $20 \%$ drop in $\mathrm{FEV}_{1}$; PEFR: peak expiratory flow rate; RCT: randomised controlled trial; SABA: short-acting beta-agonists; SC:

subcutaneous; SGRQ: St George's Respiratory Questionnaire.

\section{Lung function}

\begin{tabular}{|c|c|c|c|c|c|c|c|c|c|}
\hline \multirow[b]{2}{*}{ Study } & \multirow[b]{2}{*}{ Outcome } & \multicolumn{3}{|c|}{ Intervention } & \multicolumn{3}{|c|}{ Control } & \multirow[b]{2}{*}{$\begin{array}{l}\text { Median } \\
\text { difference }\end{array}$} & \multirow[b]{2}{*}{$\begin{array}{l}\text { P value } \\
\text { (between } \\
\text { groups) }\end{array}$} \\
\hline & & $\mathbf{N}$ & $\begin{array}{l}\text { Pre-dose } \\
\text { median } \\
\text { (IQR) }\end{array}$ & $\begin{array}{c}\text { Post-dose } \\
\text { median } \\
\text { (IQR) }\end{array}$ & N & $\begin{array}{l}\text { Pre-dose } \\
\text { median } \\
(\text { IQR) }\end{array}$ & $\begin{array}{l}\text { Post-dose } \\
\text { median } \\
\text { (IQR) }\end{array}$ & & \\
\hline$\frac{\text { Flood-Page }}{2003}$ & $\mathrm{FEV}_{1} \mathrm{~L} / \mathrm{s}$ & & $\begin{array}{l}3.05 \\
(2.69 \text { to } \\
3.28)\end{array}$ & $\begin{array}{l}3.1 \\
(2.82 \\
\text { to3.85) }\end{array}$ & 13 & $\begin{array}{l}3.1 \\
(2.65 \text { to } \\
3.51)\end{array}$ & $\begin{array}{l}3.06 \\
(2.65 \text { to } \\
3.45)\end{array}$ & 0.15 & 0.22 \\
\hline$\frac{\text { Flood-Page }}{2003}$ & $\begin{array}{l}\text { Morning PEFR } \\
\text { L/min }\end{array}$ & 11 & $\begin{array}{l}433 \\
\text { (402 to } 497)\end{array}$ & $\begin{array}{l}436 \\
(417 \text { to } 503)\end{array}$ & 12 & $\begin{array}{l}459.5 \\
(408 \text { to } 481)\end{array}$ & $\begin{array}{l}448 \\
(370 \text { to } 490)\end{array}$ & 21 & 0.09 \\
\hline
\end{tabular}

\section{Footnotes}

$\mathrm{FEV}_{1}$ : Forced expiratory volume in 1 second; IQR: interquartile range; PEFR: peak expiratory flow rate 
MEP-AST Mepolizumab versus placebo for asthma

\begin{tabular}{|c|c|c|c|c|c|}
\hline \multirow[b]{2}{*}{ Outcome } & \multicolumn{2}{|l|}{ Intervention } & \multicolumn{2}{|l|}{ Control } & \multirow[b]{2}{*}{$P$ value } \\
\hline & $\mathrm{N} \mid \begin{array}{l}\text { Pre-dose } \\
\text { median (IQR) }\end{array}$ & $\begin{array}{l}\text { Post-dose } \\
\text { median (IQR) }\end{array}$ & $\mathrm{N} \begin{array}{l}\text { Pre-dose } \\
\text { median (IQR) }\end{array}$ & $\begin{array}{l}\text { Post-dose } \\
\text { median (IQR) }\end{array}$ & \\
\hline $\begin{array}{l}\text { BALF (\% cell type on cytospin) } \\
\text { Eosinophils }\end{array}$ & $\left.11\right|_{(0.9} ^{1.4}$ to 10.2$)$ & $\begin{array}{l}0.3 \\
(0.01 \text { to } 0.8)\end{array}$ & $13\left(\begin{array}{l}1.2 \\
(0.2 \text { to } 6)\end{array}\right.$ & $\begin{array}{l}1.2 \\
(0.3 \text { to } 1.6)\end{array}$ & 0.4 \\
\hline
\end{tabular}

Footnotes

BALF: bronchoalveolar lavage fluid; IQR: interquartile range

4 Eosinophils from Haldar 2009

\begin{tabular}{|c|c|c|c|}
\hline \multirow{2}{*}{ Outcome } & Intervention & Control & \\
\hline & N Percentage & N Percentage & P value \\
\hline Geometric mean sputum eosinophil \% during exacerbation & $291.5 \%$ & $324.4 \%$ & 0.005 \\
\hline Sputum eosinophil count $>3 \%$ during exacerbation ( $\%$ of episodes) 2 & $2936 \%$ & $3259 \%$ & 0.04 \\
\hline
\end{tabular}

Footnotes

5 Sputum eosinophil results from Leckie 2000

\begin{tabular}{|c|c|c|c|}
\hline & & $\begin{array}{l}\text { Intervention } \\
\text { Mepolizumab } \\
(10 \mathrm{mg} / \mathrm{kg}) \\
\mathrm{N}=8\end{array}$ & $\begin{array}{l}\text { Intervention } \\
\text { Mepolizumab } \\
(2.5 \mathrm{mg} / \mathrm{kg}) \\
\mathrm{N}=7\end{array}$ \\
\hline Outcome & Day & Difference $(95 \% \mathrm{Cl})$ & Difference \\
\hline \multirow[t]{3}{*}{$\begin{array}{l}\text { Difference in blood eosinophils vs placebo pre- } \\
\text { allergen }\end{array}$} & $\begin{array}{l}\text { Day - } \\
14\end{array}$ & $\begin{array}{l}0.08(-0.09 \text { to } 0.26), P= \\
0.4960\end{array}$ & $0.18(0.01$ to 0.36$), P=0.0292$ \\
\hline & Day 8 & $0.17(0.04$ to 0.30$), P=0.0054$ & $0.01(-0.16$ to 0.19$), P=1.00$ \\
\hline & Day 29 & 0.21 ( 0.10 to 0.33$), P<0.0001$ & $0.02(-0.14$ to 0.18$), P=1.00$ \\
\hline \multirow[t]{3}{*}{$\begin{array}{l}\text { Difference in blood eosinophils vs placebo post- } \\
\text { allergen }\end{array}$} & $\begin{array}{l}\text { Day - } \\
13\end{array}$ & $0.38(0.07$ to 0.69$), P=0.0144$ & $\begin{array}{l}0.23(-0.11 \text { to } 0.58), P= \\
0.2136\end{array}$ \\
\hline & Day 9 & 0.34 (0.13 to 0.55$), P=0.0006$ & 0.32 (0.11 to 0.53$), P=0.0012$ \\
\hline & Day 30 & 0.49 (0.28 to 0.7$), P<0.0001$ & $0.43(0.22$ to 0.65$), P=0.0002$ \\
\hline \multirow[t]{3}{*}{ Difference in sputum eosinophils vs placebo } & Day -13 & $-2.0(-16.2$ to 12.3$), P=1.00$ & $-2.1(-16.3$ to 12.2$), P=1.00$ \\
\hline & Day 9 & 11.3 (2.6 to 20.1$), P=0.0076$ & $5.0(-5.9$ to 16.0$), P=0.6108$ \\
\hline & Day 30 & $\begin{array}{l}12.1(3.1 \text { to }-21.0), P= \\
0.0050\end{array}$ & $5.9(-5.0$ to 16.8$), P=0.4454$ \\
\hline
\end{tabular}

Footnotes

6 Sputum eosinophil results from Nair 2009

\begin{tabular}{|c|c|c|c|c|}
\hline \multirow[t]{2}{*}{ Outcome } & \multirow[t]{2}{*}{ Visit } & Intervention & Control & \multirow[t]{2}{*}{$P$ value } \\
\hline & & Nmedian (range) & $\mathrm{N}$ median (range) & \\
\hline \multirow[t]{2}{*}{ Sputum eosinophils (\%) mediar } & Visit 1 & 916.6 (1.6 to 54.3$)$ & $114.0(0$ to 35.3$)$ & $P<0.05$ compared to baseline \\
\hline & 4 weeks after first dose & $9 \begin{array}{l}0 \text { (range } 0 \text { to } \\
4.0)\end{array}$ & $103.0(0$ to 16.3$)$ & $P<0.05$ compared to baseline \\
\hline & & mean (SD) & mean (SD) & \\
\hline \multirow{2}{*}{ Blood eosinophils (x 109/L) } & Visit 1 & $9664.4(492.5)$ & $11352.1( \pm 253.7)$ & $P<0.05$ compared to baseline \\
\hline & 4 weeks after first dose 9 & $949.5(37.5)$ & $10295.8( \pm 207.4)$ & $P<0.05$ compared to baseline \\
\hline
\end{tabular}




\section{References to studies}

\section{Included studies}

\section{Buttner 2003}

Buttner C, Lun A, Splettstoesser T, Kunkel G, Renz H. Monoclonal anti-interleukin-5 treatment suppresses eosinophil but not T-cell functions. European Respiratory Journal 2003;21(5):799-803. [CRS-ID: 4900100000015258]

\section{Flood-Page 2003}

Flood-Page PT, Menzies-Gow AN, Kay AB, Robinson DS. Eosinophil's role remains uncertain as anti-interleukin-5 only partially depletes numbers in asthmatic airway [comment]. American Journal of Respiratory and Critical Care Medicine 2003;167(2):199-204. [CRS-ID: 4900100000013790; Other: 4900100000013790]

Flood-Page PT, Menzies-Gow AN, Phipps S, Compton C, Walls C, Barnes NC, et al. Reduction of tissue eosinophils in mild atopic asthmatics by an anti-IL-5 monoclonal antibody (Mepolizumab) is associated with inhibition of tenascin deposition with the bronchial epithelial basement [Abstract]. American Journal of Respiratory and Critical Care Medicine 2002;165(Suppl 8):B42. [CRS-ID: 4900100000013133]

Flood-Page PT, Menzies-Gow AN, Phipps S, Ying S, Wangoo A, Ludwig MS, et al. Anti-IL-5 treatment reduces deposition of ECM proteins in the bronchial subepithelial basement membrane of mild atopic asthmatics. Journal of Clinical Investigation 2003;112(7):1029-36. [CRS-ID: 4900100000015627]

Kay AB, Flood-Page PT, Menzies-Gow AN, Robinson DS. Effect of anti-II-5 (mezolizumab) on airway eosinophils in asthmatics. Allergy and Clinical Immunology International 2004;Suppl 1:298-301. [CRS-ID: 4900100000051661; Other: 4900100000051661]

Menzies-Gow AN, Flood-Page PT, Compton C, Walls C, Sehmi R, Robinson DS, et al. A double-blind placebo-controlled, parallel group study to assess the effect of mepolizumab (humanised monoclonal anti-il-5-antibody) on bone marrow and peripheral blood eosinophils and eosinophil progenitors in atopic asthmatics [Abstract]. In: American Journal of Respiratory and Critical Care Medicine. Vol. 165. 2002:B50. [CRS-ID: 4900100000013192]

Menzies-Gow AN, Flood-Page PT, Sehmi R, Burman J, Hamid Q, Robinson DS, et al. Anti-IL-5 (mepolizumab) therapy induces bone marrow eosinophil maturational arrest and decreases eosinophil progenitors in the bronchial mucosa of atopic asthmatics. The Journal of Allergy and Clinical Immunology 2003;111(4):714-9. [CRS-ID: 4900100000015225; Other: 4900100000015225]

Phipps S, Flood-Page PT, Menzies-Gow AN, Wangoo A, Barnes N, Barkans J, et al. Anti-IL-5 (mepolizumab) reduces the expression of tenascin procollagen III and lumican in the reticular basement membrane of human atopic asthmatics [Abstract]. In: The Journal of Allergy and Clinical Immunology. Vol. 111. 2003:S278. [CRS-ID: 4900100000018828]

\section{Flood-Page 2007}

Flood-Page PT, Swenson C, Faiferman I, Matthews J, Williams M, Brannick L, et al. A study to evaluate safety and efficacy of mepolizumab in patients with moderate persistent asthma. American Journal of Respiratory and Critical Care Medicine 2007;176(11):1062-71. [CRS-ID: 4900100000021401]

\section{Haldar 2009}

Gupta S, Halder P, Hargadon B, Sousa A, Marshall RP, Wardlaw AJ, et al. Assessment of changes in airways dimensions with mepolizumab treatment in refractory eosinophilic asthma [Abstract]. In: American Thoracic Society International Conference; 2009 May 15-20 San Diego. 2009:A3641. [CRS-ID: 4900100000024535]

Haldar P, Brightling C, Hargadon B, Gupta S, Monteiro W, Sousa A, et al. Mepolizumab (Anti-IL5) and exacerbation frequency in refractory eosinophilic asthma [Abstract]. Proceedings of the American Thoracic Society International Conference; 2009 May 15-20; San Diego. In: American Journal of Critical Care and Respiratory Medicine. Vol. 179. 2009:A3638. [CRS-ID: 4900100000024597]

Haldar P, Brightling CE, Hargadon B, Gupta S, Monteiro W, Sousa A, et al. Mepolizumab and exacerbations of refractory eosinophilic asthma. New England Journal of Medicine 2009;360(10):973-84. [CRS-ID: 4900100000023473]

Haldar P, Brightling CE, Singapuri A, Hargadon B, Gupta S, Monteiro W, et al. Outcomes after cessation of mepolizumab therapy in severe eosinophilic asthma: a 12-month follow-up analysis. The Journal of Allergy and Clinical Immunology 2014;133(3):921-3. [CRS: 4900126000009453; EMBASE: 2014156329; PubMed: 24418480]

\section{Leckie 2000}

Leckie MJ, ten Brinke A, Khan J, Diamant Z, O'Connor BJ, Walls CM, et al. Effects of an interleukin-5 blocking monoclonal antibody on eosinophils, airway hyper-responsiveness, and the late asthmatic response. The Lancet 2000;356(9248):2144-8. [CRS-ID: 4900100000010079]

\section{Nair 2009}

Ayars AG, Altman LC, Potter-Perigo S, Radford K, Wight TN, Nair P. Sputum hyaluronan and versican in severe eosinophilic asthma. International Archives of Allergy and Immunology 2013;161(1):65-73. [CRS-ID: 4900100000077338]

Ayars AG, Altman LC, Potter-Perigo S, Wight TN, Nair P. Sputum hyaluronan as a biomarker of airway remodeling in severe asthma [Abstract]. In: Journal of Allergy and Clinical Immunology. Vol. 127. 2011:AB8. [CRS-ID: 4900100000027030] 


\section{MEP-AST Mepolizumab versus placebo for asthma}

NCT00292877. The effects of a humanized anti-IL-5 monoclonal antibody (SB-240563) on asthma control, airway eosinophilia and the degree to which corticosteroid treatment can be reduced to maintain control. https://clinicaltrials.gov/ct2/show/NCT00292877 (accessed 16 January 2015). [CRS-ID: 4900100000020456]

Nair P, Pizzichini M, Kjarsgaard M, Inman M, Efthimiadis A, Pizzichini E, et al. Prednisone sparing effect of mepolizumab on eosinophilic bronchitis with or without asthma a randomized placebo controlled trial [Abstract]. In: American Thoracic Society International Conference; 2008 May 16-21; Toronto. 2008:A568[\#509]. [CRS-ID: 4900100000023006]

Nair P, Pizzichini MM, Kjarsgaard M, Inman MD, Efthimiadis A, Pizzichini E, et al. Mepolizumab for prednisone-dependent asthma with sputum eosinophilia. New England Journal of Medicine 2009;360(10):985-93. [CRS-ID: 4900100000023472]

\section{Ortega 2014}

NCT01691521. MEA115588 A randomised, double-blind, double-dummy, placebo-controlled, parallel-group, multi-centre study of the efficacy and safety of mepolizumab adjunctive therapy in subjects with severe uncontrolled refractory asthma. https://clinicaltrials.gov/ct2/show/NCT01691521 (accessed 16 January 2015). [CRS-ID: 4900126000001339]

Ortega HG, Liu MC, Pavord ID, Brusselle GG, FitzGerald JM, Chetta A, et al. Mepolizumab treatment in patients with severe eosinophilic asthma. New England Journal of Medicine 2014;371(13):1198-207. [CRS: 4900126000019751; EMBASE: 25199059; PubMed: 25199059]

\section{Pavord 2012}

NCT01000506. A multicenter, randomized, double-blind, placebo-controlled, parallel group, dose ranging study to determine the effect of mepolizumab on exacerbation rates in subjects with severe uncontrolled refractory asthma.

https://clinicaltrials.gov/ct2/show/NCT01000506 (accesssed 16 January 2015). [CRS-ID: 4900126000001337]

Ortega H, Li H, Suruki R, Albers F, Gordon D, Yancey S. Cluster analysis and characterization of response to mepolizumab: A step closer to personalized medicine for patients with severe asthma. Annals of the American Thoracic Society 2014;11(7):1011-7. [CRS: 4900126000015693; PubMed: 24983709]

Pavord I, Korn S, Howarth P, Bleecker E, Buhl R, Keene O, et al. Mepolizumab (anti-IL-5) reduces exacerbations in patients with refractory eosinophilic asthma [Abstract]. Proceedings of the European Respiratory Society 22nd Annual Congress; 2012 Sep 1-5; Vienna. In: European Respiratory Journal. Vol. 40. 2012:36s [349]. [CRS-ID: 4900100000068022]

Pavord ID, Korn S, Howarth P, Bleecker ER, Buhl R, Keene ON, et al. Mepolizumab for severe eosinophilic asthma (DREAM): a multicentre, double-blind, placebo-controlled trial. The Lancet 2012;380(9842):651-9. [CRS-ID: 4900100000063432]

\section{Excluded studies}

\section{Alvarez-Cuesta 1994}

Alvarez-Cuesta E, Cuesta-Herranz J, Puyana-Ruiz J, Cuesta-Herranz C, Blanco-Quiros A. Monoclonal antibodystandardized cat extract immunotherapy: risk-benefit effects from a double-blind placebo study. Journal of Allergy and Clinical Immunology 1994;93(3):556-66. [CRS-ID: 4900100000004347]

\section{Armentia 1992}

Armentia A, Arranz M, Martin JM, de la Fuente R, Sanchez P, Barber D, et al. Evaluation of immune complexes after immunotherapy with wheat flour in bakers' asthma. Annals of Allergy 1992;69(5):441-4. [CRS-ID: 4900100000003916]

\section{Ayres 2004}

Ayres JG, Higgins B, Chilvers ER, Ayre G, Blogg M, Fox H. Efficacy and tolerability of anti-immunoglobulin E therapy with omalizumab in patients with poorly controlled (moderate-to-severe) allergic asthma. Allergy 2004;59(7):701-8. [CRS-ID: 4900100000017042]

\section{Bel 2014}

Bel EH, Wenzel SE, Thompson PJ, Prazma CM, Keene ON, Yancey SW, et al. Oral glucocorticoid-sparing effect of mepolizumab in eosinophilic asthma. New England Journal of Medicine 2014;371(13):1189-97. [CENTRAL: 1013105; CRS: 4900126000019750; EMBASE: 25199060; PubMed: 25199060]

NCT01691508. MEA115575: A randomised, double-blind, placebo-controlled, parallel-group, multicenter study of mepolizumab adjunctive therapy to reduce steroid use in subjects with severe refractory asthma. https://clinicaltrials.gov/ct2/show/NCT01691508 (accessed 15 July 2015). [CRS-ID: 4900126000001341]

\section{Berger 2003}

Berger W, Gupta N, McAlary M, Fowler-Taylor A, McAlary M and Fowler-Taylor A. Evaluation of long-term safety of the antiIgE antibody, omalizumab, in children with allergic asthma. Annals of Allergy, Asthma \& Immunology 2003;91(2):182-8. [CRS-ID: 4900102000000524; Other: 4900102000000524]

\section{Blanken 2012}

Blanken M, Rovers M, Sanders E, Bont L. Ethical considerations and rationale of the MAKI trial: a multicenter double-blind randomized placebo-controlled trial into the preventive effect of palivizumab on recurrent wheezing associated with respiratory syncytial virus infection in children with a gestational age of 33-35 weeks. Contemporary Clinical Trials 
2012;33(6):1287-92. [CRS-ID: 4900100000067009]

\section{Blanken 2013}

Blanken MO, Rovers MM, Molenaar JM, Winkler-Seinstra PL, Meijer A, Kimpen JL, et al. Respiratory syncytial virus and recurrent wheeze in healthy preterm infants. New England Journal of Medicine 2013;368(19):1791-9. [CRS-ID:

4900100000077900; Other: 4900100000077900]

\section{Boulet 1997}

Boulet LP, Chapman KR, Cote J, Kalra S, Bhagat R, Swystun VA, et al. Inhibitory effects of an anti-lgE antibody E25 on allergen-induced early asthmatic response. American Journal of Respiratory and Critical Care Medicine 1997;155(6):183540. [CRS-ID: 4900100000005712]

\section{Bousquet 2004}

Bousquet J, Wenzel S, Holgate S, Lumry W, Freeman P, Fox H. Predicting response to omalizumab, an anti-IgE antibody, in patients with allergic asthma. Chest 2004;125(4):1378-86. [CRS-ID: 4900100000016325]

\section{Bousquet 2011}

Bousquet J, Siergiejko Z, Swiebocka E, Humbert M, Rabe KF, Smith N, et al. Persistency of response to omalizumab therapy in severe allergic (IgE-mediated) asthma. Allergy 2011;66(5):671-8. [CRS-ID: 4900100000026344]

\section{Brown 2007}

Brown R, Turk F, Dale P, Bousquet J. Cost-effectiveness of omalizumab in patients with severe persistent allergic asthma. Allergy 2007;62(2):149-53. [CRS-ID: 4900100000019948; Other: 4900100000019948]

\section{Bryant 1975}

Bryant DH, Burns MW, Lazarus L. Identification of $\lg G$ antibody as a carrier of reaginic activity in asthmatic patients. The Journal of Allergy and Clinical Immunology 1975;56(6):417-28. [CRS-ID: 4900100000024002]

\section{Bryant 1975a}

Bryant DH, Burns MW, Lazarus L. The correlation between skin tests, bronchial provocation tests and the serum level of lgE specific for common allergens in patients with asthma. Clinical Allergy 1975;5(2):145-57. [CRS-ID: 4900100000023985]

\section{Buhl 2000a}

Buhl R, Kunkel G, Soler M, Bensch G, Wolfe J, Noga O, et al. RhuMAb-25 improves asthma-specific quality of life in patients with allergic asthma. European Respiratory Journal 2000;16(Suppl 31):465s. [CRS-ID: 4900100000013847]

\section{Buhl 2000b}

Buhl R, Soler M, Fox H, Ashby M, McAlary M, Cooper J, et al. Recombinant humanized monoclonal antibody (rhuMAb) E25 in the prevention of serious asthma exacerbations. European Respiratory Journal 2000;16(Suppl 31):277s. [CRS-ID: 4900100000013848]

\section{Buhl 2002}

Buhl R, Soler M, Matz J, Townley R, O'Brien J, Noga O, et al. Omalizumab provides long-term control in patients with moderate-to- severe allergic asthma. European Respiratory Journal 2002;20(1):73-8. [CRS-ID: 4900100000012867]

\section{Bush 1985}

Bush RK, Taylor SL, Nordlee JA, Busse WW. Soybean oil is not allergenic to soybean-sensitive individuals. The Journal of Allergy and Clinical Immunology 1985;76(2 Pt 1):242-5. [CRS-ID: 4900100000001757]

\section{Busse 2001}

Busse WW, Corren J, Lanier BQ, Mcalary M, Fowler-Taylor A, Della Cioppa G, et al. Omalizumab, Anti-Ige Recombinant Humanized Monoclonal Antibody, for the Treatment of Severe Allergic Asthma. The Journal of Allergy and Clinical Immunology 2001;108(2):184-90. [CRS-ID: 4900100000010636; Other: 4900100000010636]

\section{Busse 2008}

Busse WW, Israel E, Nelson HS, Baker JW, Charous BL, Young DY, et al. Daclizumab improves asthma control in patients with moderate to severe persistent asthma: a randomized, controlled trial. American Journal of Respiratory and Critical Care Medicine 2008;178(10):1002-8. [CRS-ID: 4900100000022833]

\section{Caffarelli 2000}

Caffarelli C, Sensi LG, Marcucci F, Cavagni G. Preseasonal local allergoid immunotherapy to grass pollen in children: a double-blind, placebo-controlled, randomized trial. Allergy 2000;55(12):1142-7. [CRS-ID: 4900100000009985]

\section{Castro 2010}

Castro M, Mathur S, Hargreave F, Xie F, Young J, Wilkins HJ, et al. Reslizumab in the treatment of poorly controlled asthma in patients with eosinophilic airway inflammation [Abstract]. Annals of Allergy, Asthma \& Immunology 2010;105(5 Suppl):A43. [CRS-ID: 4900100000054093] 


\section{Castro 2011}

Castro M, Mathur S, Hargreave F, Boulet LP, Xie F, Young J, et al. Reslizumab for poorly controlled, eosinophilic asthma: a randomized, placebo-controlled study. American Journal of Respiratory and Critical Care Medicine 2011;184(10):1125-32. [CRS-ID: 4900100000056192]

\section{Chandra 1989}

Chandra RK, Singh G, Shridhara B. Effect of feeding whey hydrolysate, soy and conventional cow milk formulas on incidence of atopic disease in high risk infants. Annals of Allergy 1989;63(2):102-6. [CRS-ID: 4900100000002896]

\section{Chervinsky 2003}

Chervinsky P, Casale T, Townley R, Tripathy I, Hedgecock S, Fowler-Taylor A, et al. Omalizumab, an anti-IgE antibody, in the treatment of adults and adolescents with perennial allergic rhinitis. Annals of Allergy, Asthma \& Immunology 2003;91(2):160-7. [CRS-ID: 4900100000015346; Other: 4900100000015346]

\section{Clavel 1998}

Clavel R, Bousquet J, Andre C. Clinical efficacy of sublingual-swallow immunotherapy: a double-blind, placebo-controlled trial of a standardized five-grass-pollen extract in rhinitis. Allergy 1998;53(5):493-8. [CRS-ID: 4900100000023536]

\section{Corren 2003}

Corren J, Casale T, Deniz Y, Ashby M. Omalizumab, a recombinant humanized anti-lgE antibody, reduces asthma-related emergency room visits and hospitalizations in patients with allergic asthma. The Journal of Allergy and Clinical Immunology 2003;111(1):87-90. [CRS-ID: 4900100000015187]

\section{Corren 2010}

Corren J, Busse W, Meltzer EO, Mansfield L, Bensch G, Fahrenholz J, et al. A randomized, controlled, phase 2 study of AMG 317, an IL-4Ralpha antagonist, in patients with asthma. American Journal of Respiratory and Critical Care Medicine 2010;181(8):788-96. [CRS-ID: 4900100000024877]

\section{Cullell-Young 2002}

Cullell-Young M, Bayes M, Leeson PA. Omalizumab: Treatment of allergic rhinitis, treatment of asthma. Drugs of the Future 2002;27(6):537-45. [CRS-ID: 4900100000050549]

\section{De Boever 2014}

De Boever EH, Ashman C, Cahn AP, Locantore NW, Overend P, Pouliquen IJ, et al. Efficacy and safety of an anti-IL-13 mAb in patients with severe asthma: A randomized trial. The Journal of Allergy and Clinical Immunology 2014;133(4):989-996. [ CENTRAL: 984687; CRS: 4900126000011203; EMBASE: 2014224342; PubMed: 24582316]

\section{Djukanovic 2004}

Djukanovic R, Wilson SJ, Kraft M, Jarjour NN, Steel M, Chung KF, et al. Effects of treatment with anti-immunoglobulin E antibody omalizumab on airway inflammation in allergic asthma. American Journal of Respiratory and Critical Care Medicine 2004;170(6):583-93. [CRS-ID: 4900100000017162]

\section{Ebner 1989}

Ebner H, Neuchrist C, Havelec L, Kraft D. [Comparative studies of the effectiveness of specific immunotherapy in house dust mite allergy] [Vergleichende Untersuchungen zur Wirksamkeit einer spezifischen Immuntherapie bei HausstaubmilbenAllergie]. Wiener Klinische Wochenschrift 1989;101(15):504-11. [CRS-ID: 4900100000002906]

\section{Eckman 2010}

Eckman JA, Sterba PM, Kelly D, Alexander V, Liu MC, Bochner BS, et al. Effects of omalizumab on basophil and mast cell responses using an intranasal cat allergen challenge. The Journal of Allergy and Clinical Immunology 2010;125(4):889895.e7. [CRS-ID: 4900100000024734]

\section{El-Nawawy 2000}

El-Nawawy AA, Massoud MN, El-Nazzar SY, Ramy BB. Pulmonary tuberculosis as a cause of recurrent wheezy chest: the value of serological diagnosis using IgG antibodies to mycobacterium $38 \mathrm{kDa}$ antigen. Journal of Tropical Pediatrics 2000;46(1):53-4. [CRS-ID: 4900100000008353]

\section{Fahy 1997}

Fahy JV, Fleming HE, Wong HH, Liu JT, Su JQ, Reimann J, et al. The effect of an anti-lgE monoclonal antibody on the earlyand late-phase responses to allergen inhalation in asthmatic subjects. American Journal of Respiratory and Critical Care Medicine 1997;155(6):1828-34. [CRS-ID: 4900100000005711]

\section{Fahy 1999}

Fahy JV, Cockcroft DW, Boulet LP, Wong HH, Deschesnes F, Davis EE, et al. Effect of aerosolized anti-IgE (E25) on airways responses to inhaled allergen in asthmatic subjects. American Journal of Respiratory and Critical Care Medicine 1999;160(3):1023-7. [CRS-ID: 4900100000006519; Other: 4900100000006519] 


\section{Finn 2003}

Finn A, Gross G, Van Bavel J, Lee T, Windom H, Everhard F, et al. Omalizumab improves asthma-related quality of life in patients with severe allergic asthma. The Journal of Allergy and Clinical Immunology 2003;111(2):278-84. [CRS-ID: 4900100000013800]

\section{Frew 1998}

Frew AJ. Effects of anti-IgE in asthmatic subjects. Thorax 1998;53(Suppl 2):S52-7. [CRS-ID: 4900100000010183; Other: 4900100000010183]

\section{Garcia 2013}

Garcia G, Magnan A, Chiron R, Contin-Bordes C, Berger P, Taillé C, et al. A proof-of-concept, randomized, controlled trial of omalizumab in patients with severe, difficult-to-control, nonatopic asthma. Chest 2013;144(2):411-9. [CENTRAL: 872766; CRS: 4900100000089187; EMBASE: 2013508319; PubMed: 23579324]

\section{Gauvreau 2011}

Gauvreau GM, Boulet LP, Cockcroft DW, Fitzgerald JM, Carlsten C, Davis BE, et al. Effects of interleukin-13 blockade on allergen-induced airway responses in mild atopic asthma. American Journal of Respiratory and Critical Care Medicine 2011;183(8):1007-14. [CRS-ID: 4900100000026369]

\section{Gauvreau 2014a}

Gauvreau GM, O'Byrne PM, Boulet LP, Wang Y, Cockcroft D, Bigler J, et al. Effects of an anti-TSLP antibody on allergeninduced asthmatic responses. New England Journal of Medicine 2014;370(22):2102-10. [CENTRAL: 991614; CRS: 4900126000014666; Other: 4900126000014666; PubMed: 24846652]

\section{Gauvreau 2014b}

Gauvreau GM, Boulet LP, Cockcroft DW, Fitzgerald JM, Mayers I, Carlsten C, et al. OX40L blockade and allergen-induced airway responses in subjects with mild asthma. Clinical and Experimental Allergy 2014;44(1):29-37. [CENTRAL: 961627; CRS: 4900126000003111; EMBASE: 2013812052; PubMed: 24224471]

\section{Gauvreau 2014c}

Gauvreau GM, Harris JM, Boulet LP, Scheerens H, Fitzgerald JM, Putnam WS, et al. Targeting membrane-expressed lgE B cell receptor with an antibody to the M1 prime epitope reduces IgE production. Science Translational Medicine 2014;6(243):243ra85. [CENTRAL: 994063; CRS: 4900126000015683; PubMed: 24990880]

\section{Gevaert 2013}

Gevaert P, Calus L, Van Zele T, Blomme K, De Ruyck N, Bauters W, et al. Omalizumab is effective in allergic and nonallergic patients with nasal polyps and asthma. The Journal of Allergy and Clinical Immunology 2013;131(1):110-6.e1. [CRS-ID: 4900100000072110]

\section{Gordon 1972}

Gordon VH, Caplinger KJ, Meade JHJ, Thompson C. Correlation of type specific fluorescent antibodies to ragweed with symptomatology: double-blind study. Annals of Allergy 1972;30(9):507-17. [CRS-ID: 4900100000000354]

\section{Greenberg 1991}

Greenberg RN, Wilson KM, Kunz AY, Wedel NI, Gorelick KJ. Randomized, double-blind phase II study of anti-endotoxin antibody (E5) as adjuvant therapy in humans with serious gram-negative infections. Progress in Clinical and Biological Research 1991;367:179-86. [CRS-ID: 4900100000003509]

\section{Han 2009}

Han JQ, Zhu YX. Efficacy and regulation of humoral immunity of jade screen powder as an adjunct therapy in children with asthma [搜索关键词]. Zhongguo Dang Dai Er Ke Za Zhi [Chinese Journal of Contemporary Pediatrics] 2009;11(7):587-8. [CRS-ID: 4900100000024253]

\section{Hanania 2011}

Hanania NA, Alpan O, Hamilos DL, Condemi JJ, Reyes-Rivera I, Zhu J, et al. Omalizumab in severe allergic asthma inadequately controlled with standard therapy: a randomized trial [Summary for patients]. Annals of Internal Medicine 2011;154(9):573-82. [CRS-ID: 4900100000026408]

\section{Hanania 2013}

Hanania NA, Wenzel S, Rosen K, Hsieh HJ, Mosesova S, Choy DF, et al. Exploring the effects of omalizumab in allergic asthma: an analysis of biomarkers in the EXTRA study. American Journal of Respiratory and Critical Care Medicine 2013;187(8):804-11. [CRS-ID: 4900100000077549; Other: 4900100000077549]

\section{Hanania 2014}

Hanania NA, Noonan MJ, Corren J, Korenblat P, Zheng Y, Putnam W, et al. Efficacy and safety of lebrikizumab in severe uncontrolled asthma: Results from the lute and verse phase II randomized, double-blind, placebo-controlled trials. The Journal of Allergy and Clinical Immunology 2014;133(2 Suppl):AB402. [CENTRAL: 985853; CRS: 4900126000010490; 
EMBASE: 71351759]

\section{Hill 1982}

Hill DJ, Smart IJ, Hosking CS. Specific cellular and humoral immunity in children with grass pollen asthma. Clinical Allergy 1982;12(1):83-9. [CRS-ID: 4900100000001231]

\section{Hodsman 2013}

Hodsman P, Ashman C, Cahn A, De Boever E, Locantore N, Serone A, et al. A phase 1, randomized, placebo-controlled, dose-escalation study of an anti-IL-13 monoclonal antibody in healthy subjects and mild asthmatics. British Journal of Clinical Pharmacology 2013;75(1):118-28. [CRS-ID: 4900100000070660]

\section{Holgate 2004}

Holgate ST, Chuchalin AG, Hebert J, Lotvall J, Persson GB, Chung KF, et al. Efficacy and safety of a recombinant antiimmunoglobulin E antibody (omalizumab) in severe allergic asthma. Clinical and Experimental Allergy 2004;34(4):632-8. [CRS-ID: 4900100000016275]

\section{Hoshino 2012}

Hoshino M, Ohtawa J. Effects of adding omalizumab, an anti-immunoglobulin E antibody, on airway wall thickening in asthma. Respiration; International Review of Thoracic Diseases 2012;83(6):520-8. [CRS-ID: 4900100000062323]

\section{Humbert 2005}

Humbert M, Beasley R, Ayres J, Slavin R, Hebert J, Bousquet J, et al. Benefits of omalizumab as add-on therapy in patients with severe persistent asthma who are inadequately controlled despite best available therapy (GINA 2002 step 4 treatment): INNOVATE. Allergy 2005;60(3):309-16. [CRS-ID: 4900100000018078]

\section{Humbert 2008}

Humbert M, Berger W, Rapatz G, Turk F. Add-on omalizumab improves day-to-day symptoms in inadequately controlled severe persistent allergic asthma. Allergy 2008;63(5):592-6. [CRS-ID: 4900100000021856; Other: 4900100000021856]

\section{Humbert 2009}

Humbert M, Boulet LP, Niven RM, Panahloo Z, Blogg M, Ayre G. Omalizumab therapy: patients who achieve greatest benefit for their asthma experience greatest benefit for rhinitis. Allergy 2009;64(1):81-4. [CRS-ID: 4900100000023513]

\section{Jacquemin 1995}

Jacquemin MG, Saint-Remy JM. Specific down-regulation of anti-allergen IgE and IgG antibodies in humans associated with injections of allergen-specific antibody complexes. Therapeutic Immunology 1995;2(1):41-52. [CRS-ID: 4900100000004951]

\section{Jutel 2005}

Jutel M, Jaeger L, Suck R, Meyer H, Fiebig H, Cromwell O. Allergen-specific immunotherapy with recombinant grass pollen allergens. The Journal of Allergy and Clinical Immunology 2005;116(3):608-13. [CRS-ID: 4900100000019019]

\section{Kang 1988}

Kang BC, Johnson J, Morgan C, Chang JL. The role of immunotherapy in cockroach asthma. Journal of Asthma 1988;25(4):205-18. [CRS-ID: 4900100000008263]

\section{Kips 2003}

Kips JC, O'Connor BJ, Langley SJ, Woodcock A, Kerstjens HA, Postma DS, et al. Effect of SCH55700, a humanized antihuman interleukin-5 antibody, in severe persistent asthma: a pilot study. American Journal of Respiratory and Critical Care Medicine 2003;167(12):1655-9. [CRS-ID: 4900100000015121]

\section{Kon 2001}

Kon OM, Sihra BS, Loh LC, Barkans J, Compton CH, Barnes NC, et al. The effects of an anti-CD4 monoclonal antibody, keliximab, on peripheral blood CD4+ T-cells in asthma. European Respiratory Journal 2001;18(1):45-52. [CRS-ID: 4900100000011111; Other: 4900100000011111]

\section{Kopp 2009}

Kopp MV, Hamelmann E, Zielen S, Kamin W, Bergmann KC, Sieder C, et al. Combination of omalizumab and specific immunotherapy is superior to immunotherapy in patients with seasonal allergic rhinoconjunctivitis and co-morbid seasonal allergic asthma. Clinical and Experimental Allergy 2009;39(2):271-9. [CRS-ID: 4900100000023284]

\section{Kopp 2013}

Kopp MV, Hamelmann E, Bendiks M, Zielen S, Kamin W, Bergmann KC, et al. Transient impact of omalizumab in pollen allergic patients undergoing specific immunotherapy. Pediatric Allergy and Immunology 2013;24(5):427-33. [CENTRAL: 870929; CRS: 4900100000087210; EMBASE: 2013483684; PubMed: 23799935]

\section{Kulus 2010}

Kulus M, Hebert J, Garcia E, Fowler Taylor A, Fernandez Vidaurre C, Blogg M. Omalizumab in children with inadequately controlled severe allergic (IgE-mediated) asthma. Current Medical Research and Opinion 2010;26(6):1285-93. [CRS-ID: 
4900100000025421]

\section{Lanier 2003}

Lanier BQ, Corren J, Lumry W, Liu J, Fowler-Taylor A, Gupta N. Omalizumab is effective in the long-term control of severe allergic asthma. Annals of Allergy, Asthma \& Immunology 2003;91(2):154-9. [CENTRAL: 440250; CRS: 4900100000015345; PubMed: 12952109]

\section{Lanier 2009}

Lanier B, Bridges T, Kulus M, Taylor AF, Berhane I, Vidaurre CF. Omalizumab for the treatment of exacerbations in children with inadequately controlled allergic (IgE-mediated) asthma. The Journal of Allergy and Clinical Immunology 2009;124(6):1210-6. [CENTRAL: 731495; CRS: 4900100000024431; EMBASE: 2009623072; PubMed: 19910033]

\section{Laviolette 2013}

Laviolette M, Gossage DL, Gauvreau G, Leigh R, Olivenstein R, Katial R, et al. Effects of benralizumab on airway eosinophils in asthmatic patients with sputum eosinophilia. The Journal of Allergy and Clinical Immunology 2013;132(5):1086-96.e5. [CENTRAL: 874819; CRS: 4900126000001561; EMBASE: 2013693094; PubMed: 23866823]

\section{Leynadier 2004}

Leynadier F, Doudou O, Gaouar H, Le Gros V, Bourdeix I, Guyomarch-Cocco L, et al. Effect of omalizumab in health care workers with occupational latex allergy. The Journal of Allergy and Clinical Immunology 2004;113(2):360-1. [CRS-ID: 4900100000016361]

\section{Lizaso 2008}

Lizaso MT, Tabar AI, Garcia BE, Gomez B, Algorta J, Asturias JA, et al. Double-blind, placebo-controlled Alternaria alternata immunotherapy: in vivo and in vitro parameters. Pediatric Allergy and Immunology 2008;19(1):76-81. [CRS-ID: 4900100000021781]

\section{Massanari 2009}

Massanari M, Kianifard F, Zeldin R K, Geba G P. Efficacy of omalizumab in cat-allergic patients with moderate-to-severe persistent asthma. Allergy and Asthma Proceedings 2009;30(5):534-9. [CENTRAL: 728392; CRS: 4900100000024363; PubMed: 19467177

\section{Massanari 2010}

Massanari M, Nelson H, Casale T, Busse W, Kianifard F, Geba GP, et al. Effect of pretreatment with omalizumab on the tolerability of specific immunotherapy in allergic asthma. The Journal of Allergy and Clinical Immunology 2010;125(2):383-9. [CRS-ID: 4900100000024484]

\section{Mathur 2011}

Mathur S, Castro M, Hargreave F, Xie F, Wilkins HJ, Henkel T, et al. Efficacy of reslizumab in patients with poorly controlled eosinophilic asthma: subgroup analysis of patients with nasal polyps [Abstract]. In: Journal of Allergy and Clinical Immunology. Vol. 127. 2011:AB84. [CRS-ID: 4900100000026800]

\section{Metzger 1998}

Metzger WJ, Fick RB, Bush RK, Busse W, Casale T, Chodosh S. Corticosteroid (CS) withdrawal in a study of recombinant humanized monoclonal antibody to IgE (rhu MAbE25) [Abstract]. The Journal of Allergy and Clinical Immunology 1998;101(1 Suppl):S231. [CRS-ID: 4900100000023644]

\section{Milgrom 1999}

Milgrom H, Fick RB, Su JQ, Reimann JD, Bush RK, Watrous ML, et al. Treatment of allergic asthma with monoclonal anti-IgE antibody. RhuMAb-E25 Study Group. New England Journal of Medicine 1999;341(26):1966-73. [CRS-ID: 4900100000007996]

\section{Milgrom 2001}

Milgrom H, Berger W, Nayak A, Gupta N, Pollard S, McAlary M, et al. Treatment of childhood asthma with antiimmunoglobulin E antibody (omalizumab). Pediatrics 2001;108(2):E36. [CRS-ID: 4900100000010744]

\section{Modlin 1977}

Modlin JF, Smith DH, Harding L. Clinical trials of bivalent A/New Jersey/76-A/Victoria/75 influenza vaccines in high-risk children. Journal of Infectious Diseases 1977;136(Suppl):S626-31. [CRS-ID: 4900100000000785]

\section{Moss 1987}

Moss RB, Hsu YP, Kwasnicki JM, Sullivan MM, Reid MJ. Isotypic and antigenic restriction of the blocking antibody response to ryegrass pollen: correlation of rye group I antigen-specific lgG1 with clinical response. The Journal of Allergy and Clinical Immunology 1987;79(2):387-98. [CRS-ID: 4900100000002212]

\section{Nair 2010}

Nair P, Kjarsgaard M, Armstrong S, Efthimiadis A, O'Byrne PM, Hargreave FE. Nitric oxide in exhaled breath is poorly correlated to sputum eosinophils in patients with prednisone-dependent asthma. The Journal of Allergy and Clinical 
MEP-AST Mepolizumab versus placebo for asthma

Immunology 2010;126(2):404-6. [CENTRAL: 759797; CRS: 4900100000025377; PubMed: 20621343]

\section{NCT00802438}

NCT00802438. Eosinophilic airway inflammation: relationship to remodeling and modulation by mepolizumab.

https://clinicaltrials.gov/ct2/show/NCT00802438 (accessed 15 July 2015). [CRS-ID: 4900126000001344]

\section{NCT01366521}

NCT01366521. A multicenter, open-label, dose ranging study to determine the pharmacokinetics and pharmacodynamics of mepolizumab administered intravenously or subcutaneously to adult asthmatic subjects with elevated blood eosinophil levels. https://clinicaltrials.gov/ct2/show/NCT01366521 (accessed 15 July 2015). [CRS-ID: 4900126000001335]

\section{NCT01471327}

NCT01471327. A single blind, placebo controlled, parallel group, single ascending intravenous dose study to assess safety, olerability, pharmacokinetics and pharmacodynamics of SB-240563 (mepolizumab) in healthy japanese male subjects. https://clinicaltrials.gov/ct2/show/NCT01471327 (accessed 15 July 2015). [CRS-ID: 4900126000001343]

\section{NCT01691859}

NCT01691859. MEA115666: A multi-centre, open-label, long term safety study of mepolizumab in asthmatic subjects who participated in the MEA112997 trial. https://clinicaltrials.gov/ct2/show/NCT01691859 (accessed 15 July 2015). [CRS-ID: 4900126000001338]

\section{NCT01842607}

NCT01842607. MEA115661: A multi-centre, open-label, long-term safety study of mepolizumab in asthmatic subjects who participated in the MEA115588 or MEA115575 trials. https://clinicaltrials.gov/ct2/show/NCT01842607 (accessed 15 July 2015). [CRS-ID: 4900126000001336]

\section{NCT02135692}

NCT02135692. Study 201312: a multi-centre, open-label, study of mepolizumab in a subset of subjects with a history of life threatening/seriously debilitating asthma who participated in the MEA115661 trial. http://clinicaltrials.gov/show/NCT02135692 (accessed 15 July 2015). [CRS: 4900126000021136]

\section{NCT02293265}

NCT02293265. Identification and description of severe asthma patients in a cross-sectional study-the IDEAL study. http://clinicaltrials.gov/show/NCT02293265 (accessed 15 July 2015). [CRS: 4900126000021134]

\section{Niven 2008}

Niven R, Chung KF, Panahloo Z, Blogg M, Ayre G. Effectiveness of omalizumab in patients with inadequately controlled severe persistent allergic asthma: an open-label study. Respiratory Medicine 2008;102(10):1371-8. [CRS-ID: 4900100000023545]

\section{Noga 2003}

Noga O, Hanf G, Kunkel G. Immunological and clinical changes in allergic asthmatics following treatment with omalizumab. International Archives of Allergy and Immunology 2003;131(1):46-52. [CRS-ID: 4900100000015254; Other: 4900100000015254]

\section{Noga 2008}

Noga O, Hanf G, Kunkel G, Kleine-Tebbe J. Basophil histamine release decreases during omalizumab therapy in allergic asthmatics. International Archives of Allergy and Immunology 2008;146(1):66-70. [CENTRAL: 628876; CRS:

4900100000021809; PubMed: 18087163

\section{Noonan 2013}

Noonan M, Korenblat P, Mosesova S, Scheerens H, Arron JR, Zheng Y, et al. Dose-ranging study of lebrikizumab in asthmatic patients not receiving inhaled steroids. The Journal of Allergy and Clinical Immunology 2013;132(3):567-74.e12. [ CENTRAL: 872124; CRS: 4900100000088876; EMBASE: 2013545353; PubMed: 23726041]

Oba 2004

Oba Y, Salzman GA. Cost-effectiveness analysis of omalizumab in adults and adolescents with moderate-to-severe allergic asthma. The Journal of Allergy and Clinical Immunology 2004;114(2):265-9. [CRS-ID: 4900100000016686]

\section{Oh 2013}

Oh CK, Leigh R, McLaurin KK, Kim K, Hultquist M, Molfino NA. A randomized, controlled trial to evaluate the effect of an antiinterleukin-9 monoclonal antibody in adults with uncontrolled asthma. Respiratory Research 2013;14(1):93. [CENTRAL: 871533; CRS: 4900100000090024; EMBASE: 2013599844; Other: 4900100000090024; PubMed: 24050312]

\section{Ohashi 1997}

Ohashi Y, Nakai Y, Tanaka A, Kakinoki Y, Ohno Y, Masamoto T, et al. Serum levels of specific IgE, soluble interleukin-2 receptor, and soluble intercellular adhesion molecule-1 in seasonal allergic rhinitis. Annals of Allergy, Asthma \& Immunology 1997;79(3):213-20. [CRS-ID: 4900100000005807] 


\section{Ohman 1984}

Ohman JLJ, Findlay SR, Leitermann KM. Immunotherapy in cat-induced asthma. Double-blind trial with evaluation of in vivo and in vitro responses. The Journal of Allergy and Clinical Immunology 1984;74(3 Pt 1):230-9. [CRS-ID: 4900100000007076]

\section{Ohta 2009}

Ohta K, Miyamoto T, Amagasaki T, Yamamoto M, 1304 Study Group. Efficacy and safety of omalizumab in an Asian population with moderate-to-severe persistent asthma. Respirology 2009;14(8):1156-65. [CRS-ID: 4900100000024432]

\section{Ong 2005}

Ong YE, Menzies-Gow A, Barkans J, Benyahia F, Ou TT, Ying S, et al. Anti-lgE (omalizumab) inhibits late-phase reactions and inflammatory cells after repeat skin allergen challenge. The Journal of Allergy and Clinical Immunology 2005;116(3):55864. [CRS-ID: 4900100000019018]

\section{Parker 2010}

Parker J, Brazinsky S, Miller DS, Nayak A, Korenblat PE, Sari S, et al. Randomized, double-blind, placebo-controlled, multicenter phase 2A study to evaluate the effect of a humanized interleukin-9 monoclonal antibody (MEDI-528) on exerciseinduced bronchospasm [Abstract]. American Journal of Respiratory and Critical Care Medicine 2010;181(Meeting Abstracts):A5394. [CRS-ID: 4900100000025282]

\section{Pauli 1984}

Pauli G, Bessot JC, Bigot H, Delaume G, Hordle DA, Hirth C, et al. Clinical and immunologic evaluation of tyrosine-adsorbed Dermatophagoides pteronyssinus extract: a double-blind placebo-controlled trial. The Journal of Allergy and Clinical Immunology 1984;74(4 Pt 1):524-35. [CRS-ID: 4900100000007226]

\section{Piper 2013}

Piper E, Brightling C, Niven R, Oh C, Faggioni R, Poon K, et al. A phase II placebo-controlled study of tralokinumab in moderate-to-severe asthma. European Respiratory Journal 2013;41(2):330-8. [CRS-ID: 4900100000073595]

\section{Prieto 2006}

Prieto L, Gutierrez V, Colas C, Tabar A, Perez-Frances C, Bruno L, et al. Effect of omalizumab on adenosine 5'monophosphate responsiveness in subjects with allergic asthma. International Archives of Allergy and Immunology 2006;139(2):122-31. [CRS-ID: 4900100000019265]

\section{Pui 2010}

Pui M, Lay JC, Alexis NE, Carlsten C. Flow cytometry to identify leukocyte sub-populations in blood and induced sputum in asthmatic and healthy volunteers exposed to diesel exhaust [Abstract]. Allergy, Asthma, and Clinical Immunology 2010;6(Suppl 3):P7. [CRS-ID: 4900100000054152]

\section{Rose 2009}

Rose MA, Gruendler M, Schubert R, Kitz R, Schulze J, Zielen S. Safety and immunogenicity of sequential pneumococcal immunization in preschool asthmatics. Vaccine 2009;27(38):5259-64. [CRS-ID: 4900100000024282]

\section{Sakamoto 1984}

Sakamoto Y, Nakagawa T, Ito K, Miyamoto T. Solid-phase radioimmunoassay for the measurement of IgG antibodies specific for the house dust mite, Dermatophagoides farinae . Annals of Allergy 1984;52(4):303-8. [CRS-ID: 4900100000008622]

\section{Scheerens 2011}

Scheerens H, Arron J R, Su Z, Zheng Y, Putnam W, Erickson RW, et al. Predictive and pharmacodynamic biomarkers of interleukin-13 blockade: effect of lebrikizumab on late phase asthmatic response to allergen challenge [Abstract]. In: The Journal of Allergy and Clinical Immunology. Vol. 127. 2011:AB164. [CRS-ID: 4900100000026957]

\section{Scheerens 2014}

Scheerens H, Arron JR, Zheng Y, Putnam WS, Erickson RW, Choy DF, et al. The effects of lebrikizumab in patients with mild asthma following whole lung allergen challenge. Clinical and Experimental Allergy 2014;44(1):38-46. [CENTRAL: 961626; CRS: 4900126000003110; EMBASE: 2013812053; PubMed: 24131304]

\section{Siergiejko 2011}

Siergiejko Z, Swiebocka E, Smith N, Peckitt C, Leo J, Peachey G, et al. Oral corticosteroid sparing with omalizumab in severe allergic (IgE-mediated) asthma patients. Current Medical Research and Opinion 2011;27(11):2223-8. [CRS-ID: 4900100000056233]

\section{Silk 1998}

Silk H, Zora J, Goldstein J, Tinkelman D, Schiffman G. Response to pneumococcal immunization in children with and without recurrent infections. Journal of Asthma 1998;35(1):101-12. [CRS-ID: 4900100000008189] 


\section{MEP-AST Mepolizumab versus placebo for asthma}

Silkoff PE, Romero FA, Gupta N, Townley RG, Milgrom H. Exhaled nitric oxide in children with asthma receiving Xolair (omalizumab), a monoclonal anti-immunoglobulin E antibody. Pediatrics 2004;113(4):e308-12. [CRS-ID:

4900100000016337]

\section{Simoes 2007}

Simoes EA, Groothuis JR, Carbonell-Estrany X, Rieger CH, Mitchell I, Fredrick LM, et al. Palivizumab prophylaxis, respiratory syncytial virus, and subsequent recurrent wheezing. Journal of Pediatrics 2007;151(1):34-42, 42.e1. [CRS-ID: 4900100000023930]

\section{Singh 2010}

Singh D, Kane B, Molfino NA, Faggioni R, Roskos L, Woodcock A. A phase 1 study evaluating the pharmacokinetics, safety and tolerability of repeat dosing with a human IL-13 antibody (CAT-354) in subjects with asthma. BMC Pulmonary Medicine 2010;10:3. [CRS-ID: 4900100000024732]

\section{Slavin 2009}

Slavin RG, Ferioli C, Tannenbaum SJ, Martin C, Blogg M, Lowe PJ. Asthma symptom re-emergence after omalizumab withdrawal correlates well with increasing $\mathrm{IgE}$ and decreasing pharmacokinetic concentrations. The Journal of Allergy and Clinical Immunology 2009;123(1):107-113.e3. [CRS-ID: 4900100000022846; Other: 4900100000022846]

\section{Soler 2001}

Soler M, Matz J, Townley R, Buhl R, O'Brien J, Fox H, et al. The anti-lgE antibody omalizumab reduces exacerbations and steroid requirement in allergic asthmatics. European Respiratory Journal 2001;18(2):254-61. [CRS-ID: 4900100000011115]

\section{Sorkness 2013}

Sorkness CA, Wildfire JJ, Calatroni A, Mitchell HE, Busse WW, O'Connor GT, et al. Reassessment of omalizumab-dosing strategies and pharmacodynamics in inner-city children and adolescents. The Journal of Allergy \& Clinical Immunology in Practice 2013;1(2):163-71. [CENTRAL: 991371; CRS: 4900126000012068; PubMed: 24565455]

\section{Sthoeger 2007}

Sthoeger ZM, Eliraz A, Asher I, Berkman N, Elbirt D. The beneficial effects of Xolair (Omalizumab) as add-on therapy in patients with severe persistent asthma who are inadequately controlled despite best available treatment (GINA 2002 step IV - The Israeli arm of the INNOVATE study. Israel Medical Association Journal 2007;9(6):472-5. [CRS-ID: 4900100000021263]

\section{Sugaya 1994}

Sugaya N, Nerome K, Ishida M, Matsumoto M, Mitamura K, Nirasawa M. Efficacy of inactivated vaccine in preventing antigenically drifted influenza type A and well-matched type B. JAMA 1994;272(14):1122-6. [CRS-ID: 4900100000004523]

\section{Swanson 2014}

Swanson BN, Wang L, Ming J, Hamilton JD, Teper A, Dicioccio T, et al. Exhaled nitric oxide (FENO) and t-helper 2 cell biomarkers: can they predict treatment response to dupilumab, an il-4ra antibody, in an eosinophilic asthma population? The Journal of Allergy and Clinical Immunology 2014;133(2 Suppl):AB85. [CENTRAL: 985863; CRS: 4900126000010595; EMBASE: 71351035]

\section{Szymaniak 1998}

Szymaniak L. An attempt to block histamine release from basophils granulocytes with antibodies obtained as a result of longterm immunization [Proba blokowania uwalniania histaminy z granulocytow zasadochlonnych przeciwcialami uzyskanymi w wyniku dlugotrwalej immunizacji bakteriami]. Annales Academiae Medicae Stetinensis 1998;44:45-64. [CRS-ID: 4900100000006192]

\section{Tanaka 1993}

Tanaka Y, Ueda K, Miyazaki C, Nakayama M, Kusuhara K, Okada K, et al. Trivalent cold recombinant influenza live vaccine in institutionalized children with bronchial asthma and patients with psychomotor retardation. Pediatric Infectious Disease Journal 1993;12(7):600-5. [CRS-ID: 4900100000004155]

\section{Terr 1969}

Terr Al. Immunologic bases for injection therapy of allergic diseases. Medical Clinics of North America 1969;53(6):1257-64. [CRS-ID: 4900100000000151]

\section{Van Rensen 2009}

Van Rensen EL, Evertse CE, Van Schadewijk WA, Van Wijngaarden S, Ayre G, Mauad T, et al. Eosinophils in bronchial mucosa of asthmatics after allergen challenge: effect of anti-IgE treatment. Allergy 2009;64(1):72-80. [CRS-ID: 4900100000023512]

\section{Vignola 2004}

Vignola AM, Humbert M, Bousquet J, Boulet LP, Hedgecock S, Blogg M, et al. Efficacy and tolerability of antiimmunoglobulin $E$ therapy with omalizumab in patients with concomitant allergic asthma and persistent allergic rhinitis: SOLAR. Allergy 2004;59(7):709-17. [CRS-ID: 4900100000017155] 


\section{Wark 2003}

Wark PA, Hensley MJ, Saltos N, Boyle MJ, Toneguzzi RC, Epid GD, et al. Anti-inflammatory effect of itraconazole in stable allergic bronchopulmonary aspergillosis: a randomized controlled trial. The Journal of Allergy and Clinical Immunology 2003;111(5):952-7. [CRS-ID: 4900100000015247]

\section{Wenzel 2009}

Wenzel SE, Barnes PJ, Bleecker ER, Bousquet J, Busse W, Dahlén SE, et al. A randomized, double-blind, placebocontrolled study of tumor necrosis factor-alpha blockade in severe persistent asthma. American Journal of Respiratory and Critical Care Medicine 2009;179(7):549-58. [CRS-ID: 4900100000023441; Other: 4900100000023441]

\section{Wenzel 2013}

Wenzel S, Ford L, Pearlman D, Spector S, Sher L, Skobieranda F, et al. Dupilumab in persistent asthma with elevated eosinophil levels. New England Journal of Medicine 2013;368(26):2455-66. [CRS-ID: 4900100000076900]

\section{Zetterstrom 1972}

Zetterstrom O, Fagerberg E, Wide L. An investigation of pollen extracts from different deciduous trees in patients with springtime allergy in Sweden. Acta Allergologica 1972;27(1):15-21. [CRS-ID: 4900100000008122]

\section{Zhu 2013}

Zhu R, Zheng Y, Putnam WS, Visich J, Eisner MD, Matthews JG, et al. Population-based efficacy modelling of omalizumab in patients with severe allergic asthma inadequately controlled with standard therapy. The AAPS Journal 2013;15(2):559-70. [CRS-ID: 4900126000000432]

\section{Zielen 2013}

Zielen S, Lieb A, De La Motte S, Wagner F, de Monchy J, Fuhr R, et al. Omalizumab protects against allergen-induced bronchoconstriction in allergic (immunoglobulin E-mediated) asthma. International Archives of Allergy and Immunology 2013;160(1):102-10. [CRS-ID: 4900100000072111]

\section{Studies awaiting classification}

\section{Ongoing studies}

\section{NCT01520051 2012}

NCT01520051. The efficacy of mepolizumab treatment on rhinovirus induced asthma exacerbations. https://clinicaltrials.gov/show/NCT01520051 (accessed 15 July 2015). [CRS-ID: 4900126000001342]

\section{NCT02281318 2014}

NCT02281318. A randomised, double-blind, placebo-controlled, parallel-group, multi-centre 24-week study to evaluate the efficacy and safety of mepolizumab adjunctive therapy in subjects with severe eosinophilic asthma on markers of asthma control. http://clinicaltrials.gov/show/NCT02281318 (accessed 15 July 2015). [CRS: 4900126000021132]

\section{Other references}

\section{Additional references}

Braman 2006

Braman SS. The global burden of asthma. Chest 2006;130(1 Suppl):4S-12S.

\section{BTS/SIGN 2014}

British Thoracic Society, Scottish Intercollegiate Guidelines Network. British guideline on the management of asthma. Thorax 2014;69(Suppl. 1):i1-i192.

\section{CDC 2011}

Centers for Disease Control and Prevention. Trends in asthma prevalence, health care, and mortality in the United States, 2001-2010. www.cdc.gov/nchs/data/databriefs/db94.htm (accessed 10 December 2012).

\section{CDC 2012}

Centers for Disease Control and Prevention. Vital signs. www.cdc.gov/vitalsigns/asthma/ (accessed 10 December 2013 ).

\section{Clayton 2005}

Clayton S. Paediatric asthma: overcoming barriers to an improved quality of life. British Journal of Nursing 2005;14(2):80-5.

\section{Fuhlbrigge 2012}

Fuhlbrigge A, Peden D, Apter A, Boushey HA, Camargo CA Jr, Gern J, et al. Asthma outcomes: exacerbations. The Journal of Allergy and Clinical Immunology 2012;129(3 Suppl):S34-S48.

\section{Gibson 1993}

Gibson PG, Talbot PI, Hancock J, Hensley MJ. A prospective audit of asthma management following emergency asthma treatment at a teaching hospital. Medical Journal of Australia 1993;158:775-8. 


\section{GINA 2012}

Global Intitiative for Asthma. Pocket guide for asthma management and prevention (for adults and children older than 5 years). http://www.ginasthma.org/local/uploads/files/GINA_Pocket2013_May15.pdf (accessed 5 November 2013).

\section{Higgins 2011}

Higgins JPT, Green S (editors). Cochrane Handbook for Systematic Reviews of Interventions Version 5.1.0 [updated March 2011]. The Cochrane Collaboration, 2011. www.cochrane-handbook.org.

\section{Kandane-Rathayake 2009}

Kandane-Rathnayake RK, Matheson MC, Simpson JA, Tang MLK, Johns DP, Mészáros D, et al. Adherence to asthma management guidelines by middle-aged adults with current asthma. Thorax 2009;64(12):1025-31.

\section{Krishnan 2006}

Krishnan V, Diette GB, Rand CS, Bilderback AL, Merriman B, Hansel NN, et al. Mortality in patients hospitalized for asthma exacerbations in the United States. American Journal of Respiratory and Critical Care Medicine 2006;174(6):633-8.

\section{Liu 2013}

Liu Y, Zhang S, Li DW, Jiang S-J. Efficacy of anti-interleukin-5 therapy with mepolizumab in patients with asthma: a metaanalysis of randomized placebo-controlled trials. PLoS One 2013;8(3):e59872. [DOI: 10.1371/journal.pone.0059872]

\section{Masoli 2004}

Masoli M, Fabian D, Holt S, Beasley R. The global burden of asthma: executive summary of the GINA Dissemination Committee Report. Allergy 2004;59:469-78.

\section{NHS 2011}

Health and Social Care Information Centre. Hospital Episode Statistics. www.hesonline.nhs.uk (accessed 10 December 2012).

\section{NIH 2007}

National Heart, Lung, and Blood Institute. Guidelines for the diagnosis and management of asthma (EPR 3). www.nhlbi.nih.gov/guidelines/asthma/ (accessed 10 December 2012).

\section{Patel 2008}

Patel S, Jarvelin MR, Little M. Systematic review of worldwide variations of the prevalence of wheezing symptoms in children. Environmental Health 2009;7:57. [DOI: doi.10.1186/1476-069X-7-57]

\section{RevMan}

Review Manager (RevMan) [Computer program]. Version 5.2. Copenhagen: The Nordic Cochrane Centre, The Cochrane Collaboration, 2012.

\section{WHO 2007}

Cruz AA, Mantzouranis E, Matricardi PM, Minelli E, Aït-Khaled N, Bateman ED, et al. Global Surveillance, prevention and control of chronic respiratory diseases. A comprehensive approach. Geneva: World Health Organization, 2007.

\section{WHO 2011}

World Health Organization. Health topics: asthma. www.who.int/topics/asthma/en/ (accessed 13 September 2011).

\section{Wu 2007}

Wu F, Takaro TK. Childhood asthma and environmental interventions. Environmental Health Perspectives 2007;115(6):971-5.

\section{Other published versions of this review \\ Classification pending references \\ Data and analyses}

\section{IV Mepolizumab versus placebo}

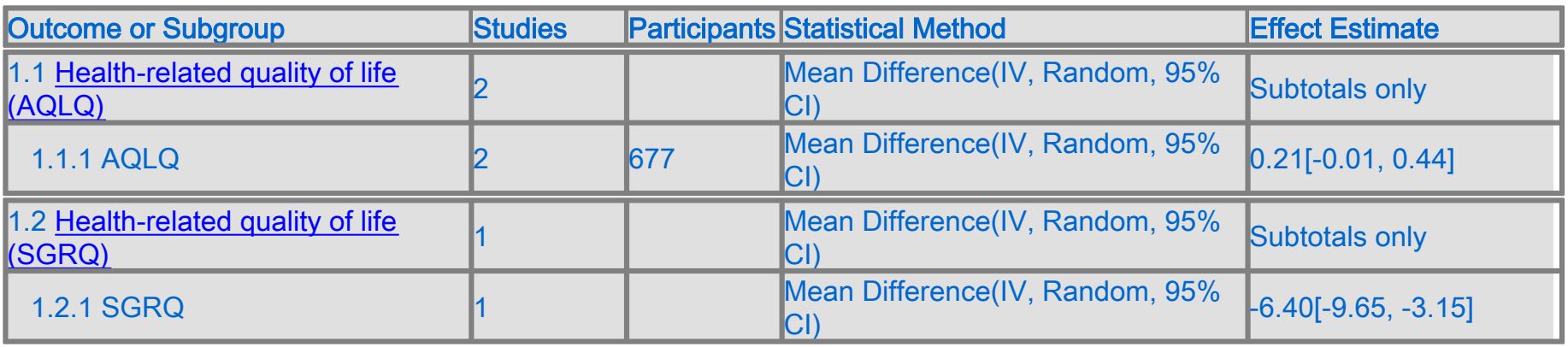


MEP-AST Mepolizumab versus placebo for asthma

\begin{tabular}{|c|c|c|c|c|}
\hline $\begin{array}{l}1.3 \text { Rate of clinically significant } \\
\text { exacerbations }\end{array}$ & 2 & & Rate Ratio(IV, Random, 95\% Cl) & Subtotals only \\
\hline $\begin{array}{l}1.3 .175 \mathrm{mg} \text { mepolizumab versus } \\
\text { placebo }\end{array}$ & 2 & 690 & Rate Ratio(IV, Random, 95\% Cl) & $0.52[0.43,0.64]$ \\
\hline $\begin{array}{l}\begin{array}{l}1.3 .2250 \mathrm{mg} \text { mepolizumab versus } \\
\text { placebo }\end{array} \\
\end{array}$ & 1 & 307 & Rate Ratio(IV, Random, 95\% Cl) & $0.61[0.46,0.81]$ \\
\hline $\begin{array}{l}1.3 .3750 \mathrm{mg} \text { mepolizumab versus } \\
\text { placebo }\end{array}$ & 1 & 311 & Rate Ratio(IV, Random, 95\% Cl) & $0.48[0.36,0.64]$ \\
\hline $\begin{array}{l}1.4 \text { Rate of exacerbations requiring } \\
\text { admission }\end{array}$ & 2 & & Rate Ratio(IV, Random, 95\% Cl) & Subtotals only \\
\hline $\begin{array}{l}1.4 .175 \mathrm{mg} \text { mepolizumab versus } \\
\text { placebo }\end{array}$ & 2 & 690 & Rate Ratio(IV, Random, 95\% Cl) & $0.61[0.33,1.13]$ \\
\hline $\begin{array}{l}1.4 .2250 \mathrm{mg} \text { mepolizumab versus } \\
\text { placebo }\end{array}$ & 1 & 307 & Rate Ratio(IV, Random, 95\% Cl) & $0.65[0.31,1.37]$ \\
\hline $\begin{array}{l}1.4 .3750 \mathrm{mg} \text { mepolizumab versus } \\
\text { placebo }\end{array}$ & 1 & 311 & Rate Ratio(IV, Random, 95\% Cl) & $0.37[0.16,0.86]$ \\
\hline $\begin{array}{l}1.5 \text { Rate of exacerbations requiring } \\
\text { ED or admission }\end{array}$ & 2 & & Rate Ratio(IV, Random, 95\% Cl) & Subtotals only \\
\hline $\begin{array}{l}1.5 .175 \mathrm{mg} \text { mepolizumab versus } \\
\text { placebo }\end{array}$ & 2 & 690 & Rate Ratio(IV, Random, 95\% Cl) & $0.52[0.31,0.87]$ \\
\hline $\begin{array}{l}1.5 .2250 \mathrm{mg} \text { mepolizumab versus } \\
\text { placebo }\end{array}$ & 1 & 307 & Rate Ratio(IV, Random, 95\% Cl) & $0.58[0.30,1.12]$ \\
\hline $\begin{array}{l}1.5 .3750 \mathrm{mg} \text { mepolizumab versus } \\
\text { placebo }\end{array}$ & 1 & 311 & Rate Ratio(IV, Random, 95\% Cl) & $0.52[0.27,1.02]$ \\
\hline $\begin{array}{l}1.6 \text { People with one or more } \\
\text { exacerbations }\end{array}$ & 4 & 467 & Risk Ratio(M-H, Random, 95\% Cl) & $0.67[0.34,1.31]$ \\
\hline 1.7 Serious adverse events & 5 & 1441 & Risk Ratio(M-H, Random, 95\% Cl) & $0.49[0.30,0.80]$ \\
\hline 1.8 FEV1 (litres) & 1 & & $\begin{array}{l}\text { Mean Difference(IV, Random, 95\% } \\
\text { CI) }\end{array}$ & Subtotals only \\
\hline $\begin{array}{l}1.8 .1250 \mathrm{mg} \text { mepolizumab versus } \\
\text { placebo }\end{array}$ & 1 & 246 & $\begin{array}{l}\text { Mean Difference(IV, Random, 95\% } \\
\text { CI) }\end{array}$ & $-0.03[-0.13,0.07]$ \\
\hline $\begin{array}{l}\begin{array}{l}1.8 .2750 \mathrm{mg} \text { mepolizumab versus } \\
\text { placebo }\end{array} \\
\end{array}$ & 1 & 242 & $\begin{array}{l}\text { Mean Difference(IV, Random, 95\% } \\
\text { (Cl) }\end{array}$ & $0.02[-0.10,0.14]$ \\
\hline 1.9 PEFR (L/min) & 1 & & $\begin{array}{l}\text { Mean Difference(IV, Random, 95\% } \\
\text { CI) }\end{array}$ & Subtotals only \\
\hline $\begin{array}{l}1.9 .1250 \mathrm{mg} \text { mepolizumab versus } \\
\text { placebo }\end{array}$ & 1 & 246 & $\begin{array}{l}\text { Mean Difference(IV, Random, 95\% } \\
\text { CI) }\end{array}$ & $13.49[0.71,26.27]$ \\
\hline $\begin{array}{l}\text { 1.9.2 } 750 \mathrm{mg} \text { mepolizumab versus } \\
\text { placebo }\end{array}$ & 1 & 242 & $\begin{array}{l}\text { Mean Difference(IV, Random, 95\% } \\
\text { CI) }\end{array}$ & $3.42[-9.40,16.24]$ \\
\hline 1.10 Post bronchodilator $\mathrm{FEV}_{1}(\mathrm{~L})$ & 3 & & $\begin{array}{l}\text { Mean Difference(IV, Random, 95\% } \\
\text { Cl) }\end{array}$ & No totals \\
\hline 1.10 .16 weeks & 1 & & $\begin{array}{l}\text { Mean Difference(IV, Random, 95\% } \\
\text { CI) }\end{array}$ & No totals \\
\hline 1.10.2 32 weeks & 1 & & $\begin{array}{l}\text { Mean Difference(IV, Random, 95\% } \\
\text { CI) }\end{array}$ & No totals \\
\hline 1.10.31 year & 1 & & $\begin{array}{l}\text { Mean Difference(IV, Random, 95\% } \\
\text { CI) }\end{array}$ & No totals \\
\hline $\begin{array}{l}1.11 \text { Percentage predicted } \mathrm{FEV}_{1} \\
\text { after bronchodilation }\end{array}$ & 1 & & $\begin{array}{l}\text { Mean Difference(IV, Random, 95\% } \\
\mathrm{CI} \text { ) }\end{array}$ & No totals \\
\hline 1.11 .16 weeks & 1 & & $\begin{array}{l}\text { Mean Difference(IV, Random, 95\% } \\
\text { CI) }\end{array}$ & No totals \\
\hline $\begin{array}{l}\text { 1.12 Pre-bronchodilator FEV } \\
\text { week } 32\end{array}$ & 1 & & $\begin{array}{l}\text { Mean Difference(IV, Random, 95\% } \\
\text { Cl) }\end{array}$ & No totals \\
\hline $\begin{array}{l}1.12 .175 \mathrm{mg} \text { mepolizumab versus } \\
\text { placebo }\end{array}$ & 1 & & $\begin{array}{l}\text { Mean Difference(IV, Random, 95\% } \\
\text { CI) }\end{array}$ & No totals \\
\hline
\end{tabular}


MEP-AST Mepolizumab versus placebo for asthma

\begin{tabular}{|c|c|c|c|c|}
\hline $\begin{array}{l}\text { 1.13 Pre-bronchodilator } \mathrm{FEV}_{1} \underline{(\mathrm{mL})} \\
\text { at week } 52\end{array}$ & 1 & & $\begin{array}{l}\text { Mean Difference(IV, Random, 95\% } \\
\mathrm{Cl})\end{array}$ & Subtotals only \\
\hline $\begin{array}{l}1.13 .175 \mathrm{mg} \text { mepolizumab versus } \\
\text { placebo }\end{array}$ & 1 & 308 & $\begin{array}{l}\text { Mean Difference(IV, Random, 95\% } \\
\mathrm{Cl})\end{array}$ & $61.00[-39.00,161.00]$ \\
\hline $\begin{array}{l}1.13 .2250 \mathrm{mg} \text { mepolizumab } \\
\text { versus placebo }\end{array}$ & 1 & 307 & $\begin{array}{l}\text { Mean Difference(IV, Random, 95\% } \\
\mathrm{Cl})\end{array}$ & $81.00[-18.51,180.51]$ \\
\hline $\begin{array}{l}1.13 .3750 \mathrm{mg} \text { mepolizumab } \\
\text { versus placebo }\end{array}$ & 1 & 311 & $\begin{array}{l}\text { Mean Difference(IV, Random, 95\% } \\
\text { Cl) }\end{array}$ & $56.00[-43.00,155.00]$ \\
\hline $\begin{array}{l}1.14 \text { Late asthmatic reaction } \\
\text { (maximum \% fall in FEV1) }\end{array}$ & 1 & & $\begin{array}{l}\text { Mean Difference(IV, Random, 95\% } \\
\mathrm{Cl} \text { ) }\end{array}$ & Subtotals only \\
\hline $\begin{array}{l}1.14 .12 .5 \mathrm{mg} / \mathrm{kg} \text { mepolizumab } \\
\text { versus placebo }\end{array}$ & 1 & 16 & $\begin{array}{l}\text { Mean Difference(IV, Random, 95\% } \\
\mathrm{CI})\end{array}$ & $3.50[-3.46,10.46]$ \\
\hline $\begin{array}{l}1.14 .27 .5 \mathrm{mg} / \mathrm{kg} \text { mepolizumab } \\
\text { versus placebo }\end{array}$ & 1 & 16 & $\begin{array}{l}\text { Mean Difference(IV, Random, 95\% } \\
\mathrm{CI})\end{array}$ & $0.30[-6.50,7.10]$ \\
\hline 1.15 Asthma symptoms & 5 & & $\begin{array}{l}\text { Mean Difference(IV, Random, 95\% } \\
\mathrm{CI})\end{array}$ & Subtotals only \\
\hline $\begin{array}{l}1.15 .175 \mathrm{mg} \text { mepolizumab versus } \\
\text { placebo }\end{array}$ & 2 & 690 & $\begin{array}{l}\text { Mean Difference(IV, Random, 95\% } \\
\mathrm{CI})\end{array}$ & $-0.30[-0.55,-0.04]$ \\
\hline $\begin{array}{l}1.15 .2250 \text { mg mepolizumab } \\
\text { versus placebo }\end{array}$ & 2 & 553 & $\begin{array}{l}\text { Mean Difference(IV, Random, 95\% } \\
\mathrm{CI})\end{array}$ & $-0.24[-0.48,0.01]$ \\
\hline $\begin{array}{l}1.15 .3750 \mathrm{mg} \text { mepolizumab } \\
\text { versus placebo }\end{array}$ & 4 & 631 & $\begin{array}{l}\text { Mean Difference(IV, Random, 95\% } \\
\text { CI) }\end{array}$ & $-0.02[-0.57,0.54]$ \\
\hline 1.16 Asthma symptoms (JACQ) & 2 & 80 & $\begin{array}{l}\text { Mean Difference(IV, Random, 95\% } \\
\mathrm{Cl})\end{array}$ & $-0.04[-0.42,0.35]$ \\
\hline
\end{tabular}

\section{SC Mepolizumab versus placebo}

\begin{tabular}{|c|c|c|c|}
\hline Outcome or Subgroup & Studies & Participants Statistical Method & Effect Estimate \\
\hline 2.1 Health-related quality of life & 1 & $\begin{array}{l}\text { Mean Difference(IV, Random, 95\% } \\
\mathrm{Cl} \text { ) }\end{array}$ & No totals \\
\hline 2.1.1 SGRQ & 1 & $\begin{array}{l}\text { Mean Difference(IV, Random, 95\% } \\
\text { CI) }\end{array}$ & No totals \\
\hline $\begin{array}{l}2.2 \text { Rate of exacerbations requiring } \\
\text { admission }\end{array}$ & 1 & Rate Ratio(IV, Random, 95\% Cl) & No totals \\
\hline $\begin{array}{l}2.3 \text { Rate of exacerbations requiring } \\
\text { ED or admission }\end{array}$ & 1 & Rate Ratio(IV, Random, 95\% Cl) & No totals \\
\hline $\begin{array}{l}2.4 \text { Rate of clinically significant } \\
\text { exacerbations }\end{array}$ & 1 & Rate Ratio(IV, Random, 95\% Cl) & No totals \\
\hline $2.5 \underline{\text { Pre bronchodilator FEV }}_{1}$ (litres) & 1 & $\begin{array}{l}\text { Mean Difference(IV, Random, 95\% } \\
\text { CI) }\end{array}$ & No totals \\
\hline 2.5.132 weeks & 1 & $\begin{array}{l}\text { Mean Difference(IV, Random, 95\% } \\
\mathrm{Cl})\end{array}$ & No totals \\
\hline 2.6 Post bronchodilator FEV 1 (litres) & 1 & $\begin{array}{l}\text { Mean Difference(IV, Random, 95\% } \\
\mathrm{CI} \text { ) }\end{array}$ & No totals \\
\hline 2.6.132 weeks & 1 & $\begin{array}{l}\text { Mean Difference(IV, Random, 95\% } \\
\mathrm{CI})\end{array}$ & No totals \\
\hline 2.7 Asthma symptoms & 1 & $\begin{array}{l}\text { Mean Difference(IV, Random, 95\% } \\
\text { Cl) }\end{array}$ & No totals \\
\hline
\end{tabular}

\section{Figures}

\section{Figure 1}


MEP-AST Mepolizumab versus placebo for asthma

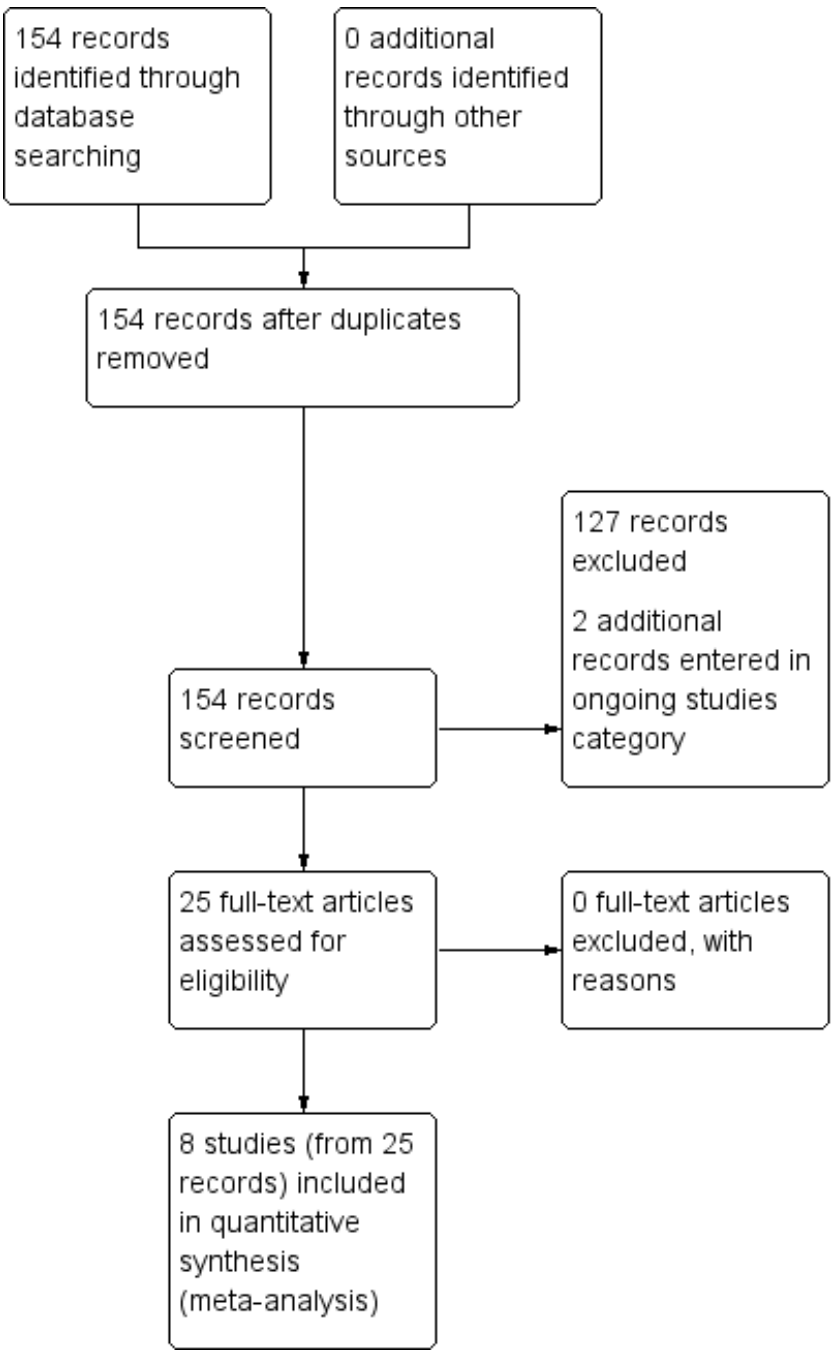

Caption

Study flow diagram

Figure 2

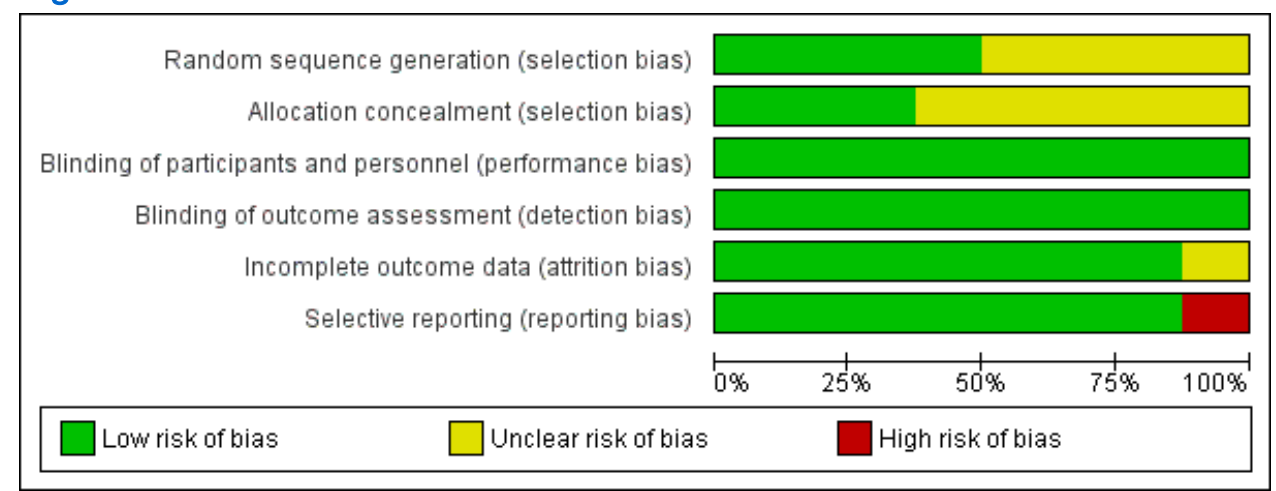

Caption

Risk of bias graph: review authors' judgements about each risk of bias item presented as percentages across all included studies.

\section{Figure 3}


MEP-AST Mepolizumab versus placebo for asthma

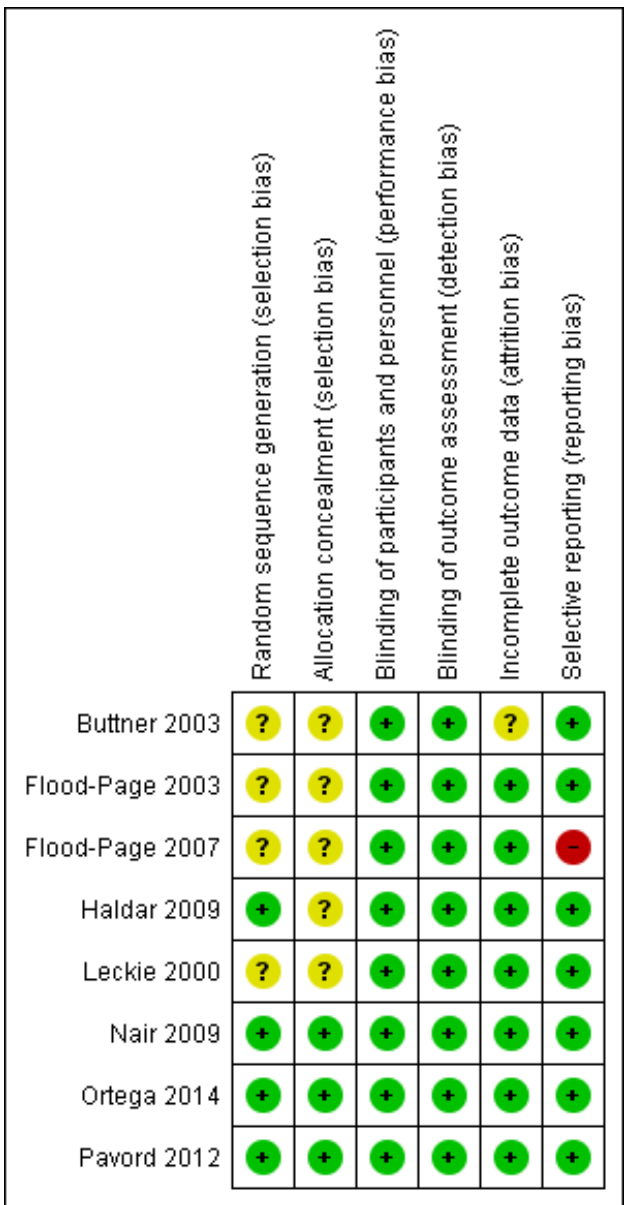

Caption

Risk of bias summary: review authors' judgements about each risk of bias item for each included study.

\section{Sources of support}

Internal sources

- No sources of support provided

External sources

- National Institute for Health Research (SJM), UK

\section{Feedback}

\section{Appendices}

1 Sources and search methods for the Cochrane Airways Group Specialised Register (CAGR)

\section{Electronic searches: core databases}

\begin{tabular}{|l|l|}
\hline Database & Frequency of search \\
\hline CENTRAL (the Cochrane Library) & Monthly \\
\hline MEDLINE (Ovid) & Weekly \\
\hline EMBASE (Ovid) & Weekly \\
\hline PsycINFO (Ovid) & Monthly \\
\hline CINAHL (EBSCO) & Monthly \\
\hline AMED (EBSCO) & Monthly \\
\hline
\end{tabular}

$\neg$

Hand-searches: core respiratory conference abstracts 
MEP-AST Mepolizumab versus placebo for asthma

\begin{tabular}{|l|l|}
\hline Conference & Years searched \\
\hline American Academy of Allergy, Asthma and Immunology (AAAAI) & 2001 onwards \\
\hline American Thoracic Society (ATS) & 2001 onwards \\
\hline Asia Pacific Society of Respirology (APSR) & 2004 onwards \\
\hline British Thoracic Society Winter Meeting (BTS) & 2000 onwards \\
\hline Chest Meeting & 2003 onwards \\
\hline European Respiratory Society (ERS) & $1992,1994,2000$ onwards \\
\hline International Primary Care Respiratory Group Congress (IPCRG) & 2002 onwards \\
\hline Thoracic Society of Australia and New Zealand (TSANZ) & 1999 onwards \\
\hline
\end{tabular}

$\neg$

\section{MEDLINE search strategy used to identify trials for the CAGR}

\section{Asthma search}

1. exp Asthma/

2. asthma\$.mp.

3. (antiasthma $\$$ or anti-asthma\$).mp.

4. Respiratory Sounds/

5. wheez\$.mp.

6. Bronchial Spasm/

7. bronchospas $\$ . m p$.

8. (bronch\$ adj3 spasm\$).mp.

9. bronchoconstrict\$.mp.

10. exp Bronchoconstriction/

11. (bronch $\$$ adj3 constrict $\$$ ).mp.

12. Bronchial Hyperreactivity/

13. Respiratory Hypersensitivity/

14. ((bronchial\$ or respiratory or airway $\$$ or lung $\$$ ) adj3 (hypersensitiv $\$$ or hyperreactiv\$ or allerg $\$$ or insufficiency)).mp.

15. ((dust or mite\$) adj3 (allerg\$ or hypersensitiv\$)).mp.

16. or/1-15

\section{Filter to identify RCTs}

1. exp "clinical trial [publication type]"/

2. (randomised or randomised).ab,ti.

3. placebo.ab,ti.

4. dt.fs.

5. randomly.ab,ti.

6. trial.ab,ti.

7. groups.ab,ti.

8. or/1-7

9. Animals/

10. Humans/

11. 9 not (9 and 10)

12. 8 not 11

The MEDLINE strategy and RCT filter are adapted to identify trials in other electronic databases.

\section{Search Strategy for Cochrane Airways Group Register}

\#1 AST:MISC1

\#2 MeSH DESCRIPTOR Asthma Explode All

\#3 asthma*:ti,ab 
MEP-AST Mepolizumab versus placebo for asthma

$\# 4 \# 1$ or \#2 or \#3

\#5 MeSH DESCRIPTOR Antibodies, Monoclonal

\#6 MeSH DESCRIPTOR Antibodies, Monoclonal, Humanized

\#7 mepolizumab*

\#8 SB24056 or SB-24056

\#9 human* NEAR2 monoclonal* NEAR2 antibod*

\#10 Bosatria

$\# 11 \# 5$ or \#6 or \#7 or \#8 or \#9 or \#10

$\# 12$ \#4 and \#11

[In search line \#1, MISC1 denotes the field where the reference has been coded for condition, in this case, asthma] 